
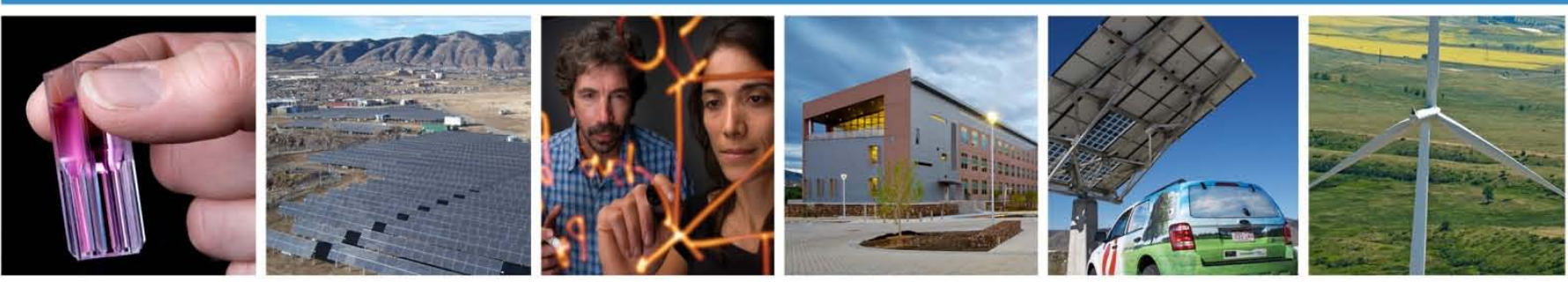

Technical Report

NREL/TP-5600-54021

January 2012

\title{
All Composite Data Products: National FCEV Learning Demonstration With Updates Through January 18, 2012
}

Keith Wipke, Sam Sprik, Jennifer Kurtz, Todd Ramsden, Chris Ainscough, and Genevieve Saur 


\section{NOTICE}

This report was prepared as an account of work sponsored by an agency of the United States government. Neither the United States government nor any agency thereof, nor any of their employees, makes any warranty, express or implied, or assumes any legal liability or responsibility for the accuracy, completeness, or usefulness of any information, apparatus, product, or process disclosed, or represents that its use would not infringe privately owned rights. Reference herein to any specific commercial product, process, or service by trade name, trademark, manufacturer, or otherwise does not necessarily constitute or imply its endorsement, recommendation, or favoring by the United States government or any agency thereof. The views and opinions of authors expressed herein do not necessarily state or reflect those of the United States government or any agency thereof.

Available electronically at http://www.osti.gov/bridge

Available for a processing fee to U.S. Department of Energy

and its contractors, in paper, from:

U.S. Department of Energy

Office of Scientific and Technical Information

\section{P.O. Box 62}

Oak Ridge, TN 37831-0062

phone: 865.576 .8401

fax: 865.576 .5728

email: mailto:reports@adonis.osti.gov

Available for sale to the public, in paper, from:

U.S. Department of Commerce

National Technical Information Service

5285 Port Royal Road

Springfield, VA 22161

phone: 800.553 .6847

fax: 703.605.6900

email: orders@ntis.fedworld.gov

online ordering: http://www.ntis.gov/help/ordermethods.aspx

Cover Photos: (left to right) PIX 16416, PIX 17423, PIX 16560, PIX 17613, PIX 17436, PIX 17721

Printed on paper containing at least $50 \%$ wastepaper, including $10 \%$ post consumer waste. 


\section{CDP\#1: Hours Accumulated and Projected Hours to $10 \%$ Stack Voltage Degradation}

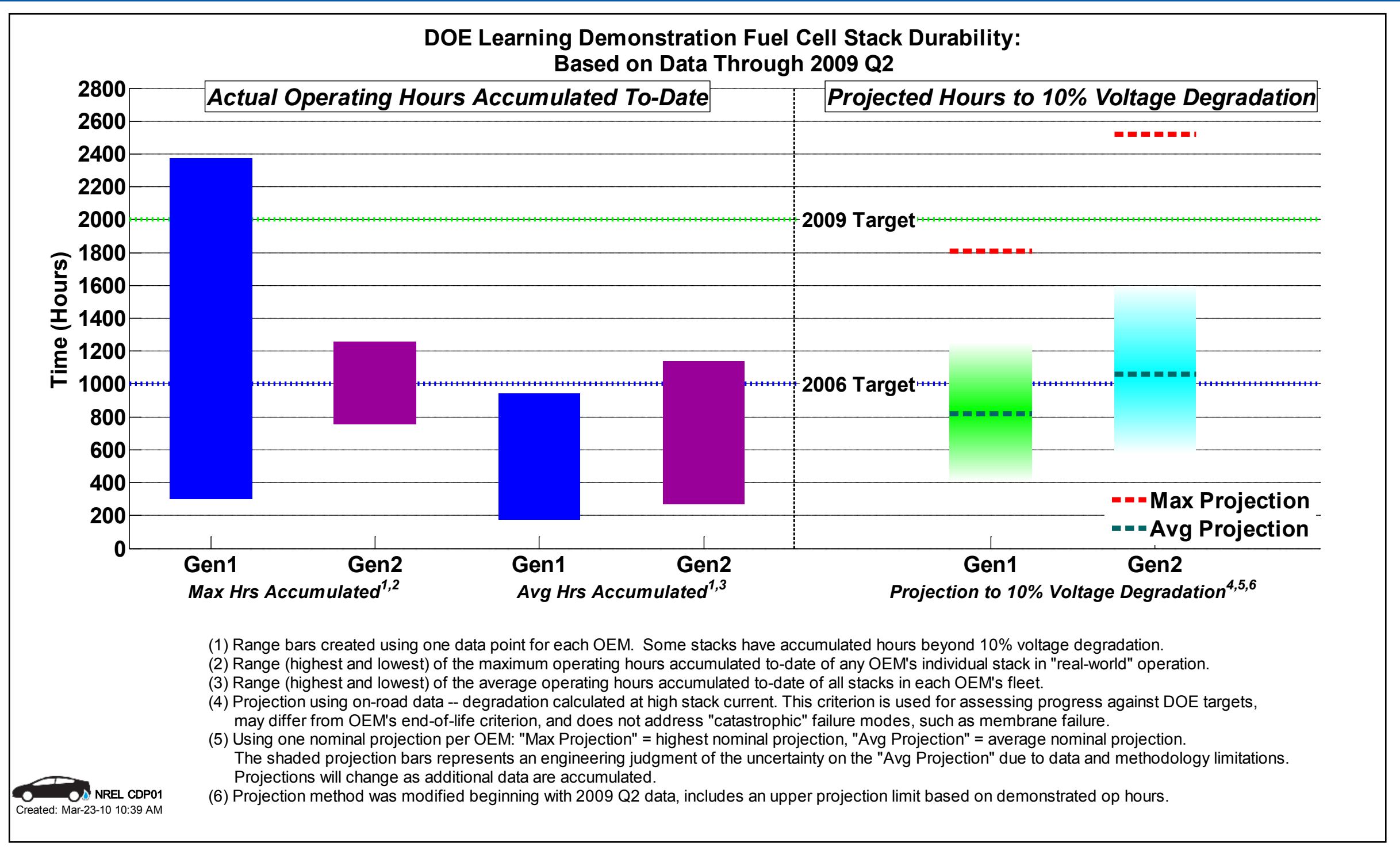




\section{CDP\#2: Vehicle Range}

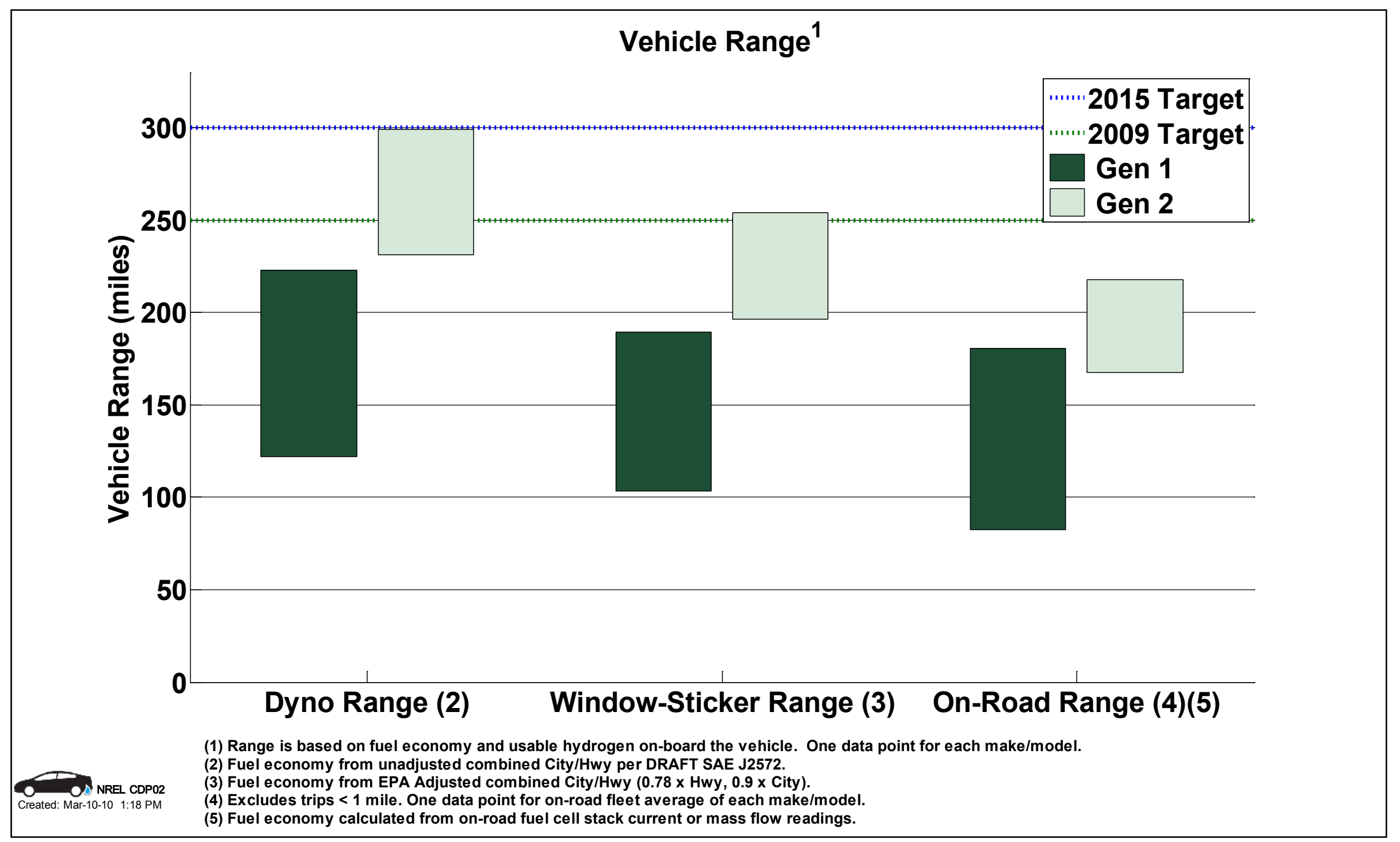




\section{CDP\#3: Fuel Cell System Power Density, Including Hydrogen Storage}

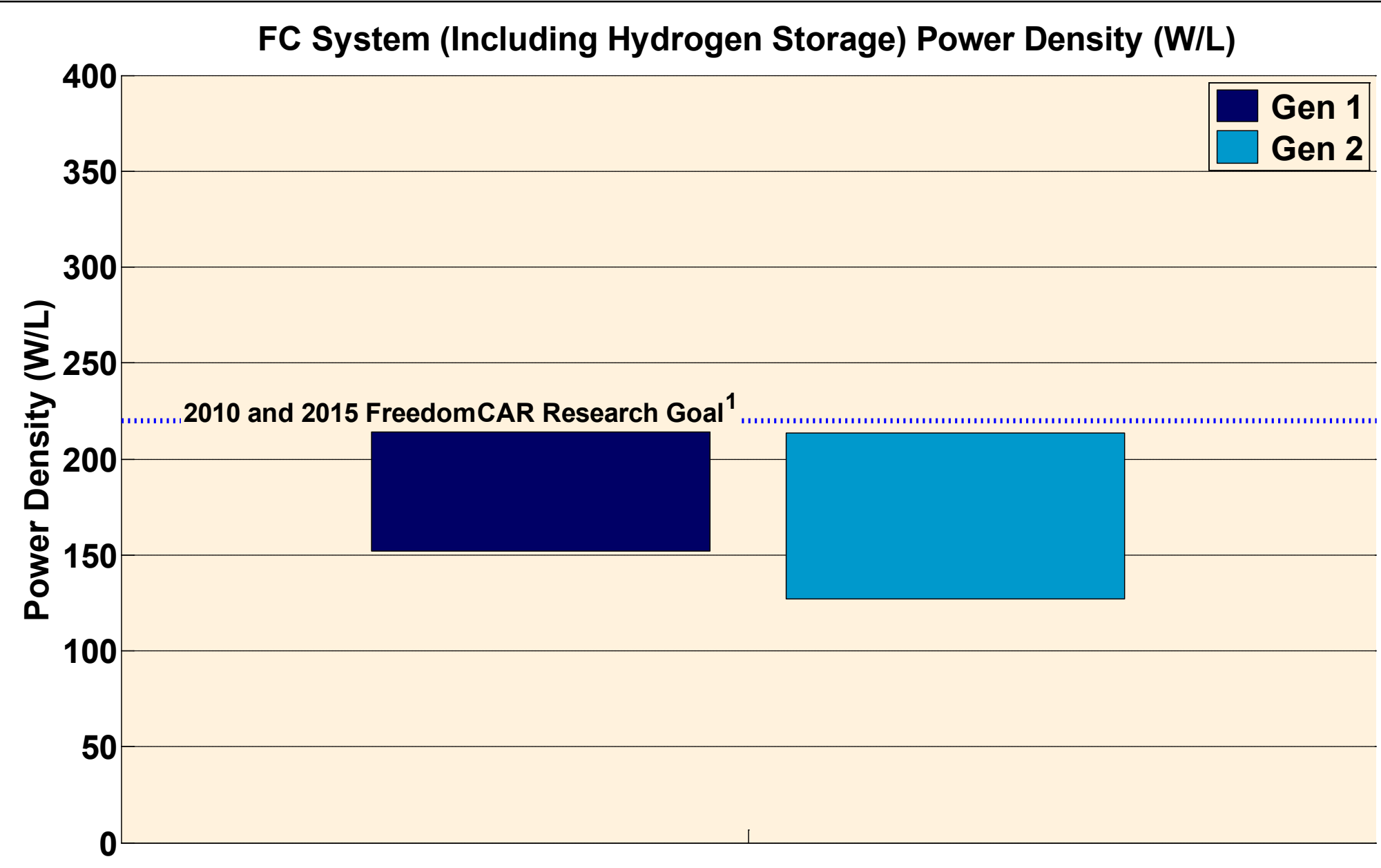

(1) Fuel cell system includes fuel cell stack, BOP and H2 storage, but excludes power electronics, battery storage, and electric drive. 


\section{CDP\#4: Fuel Cell System Specific Power, Including Hydrogen Storage}

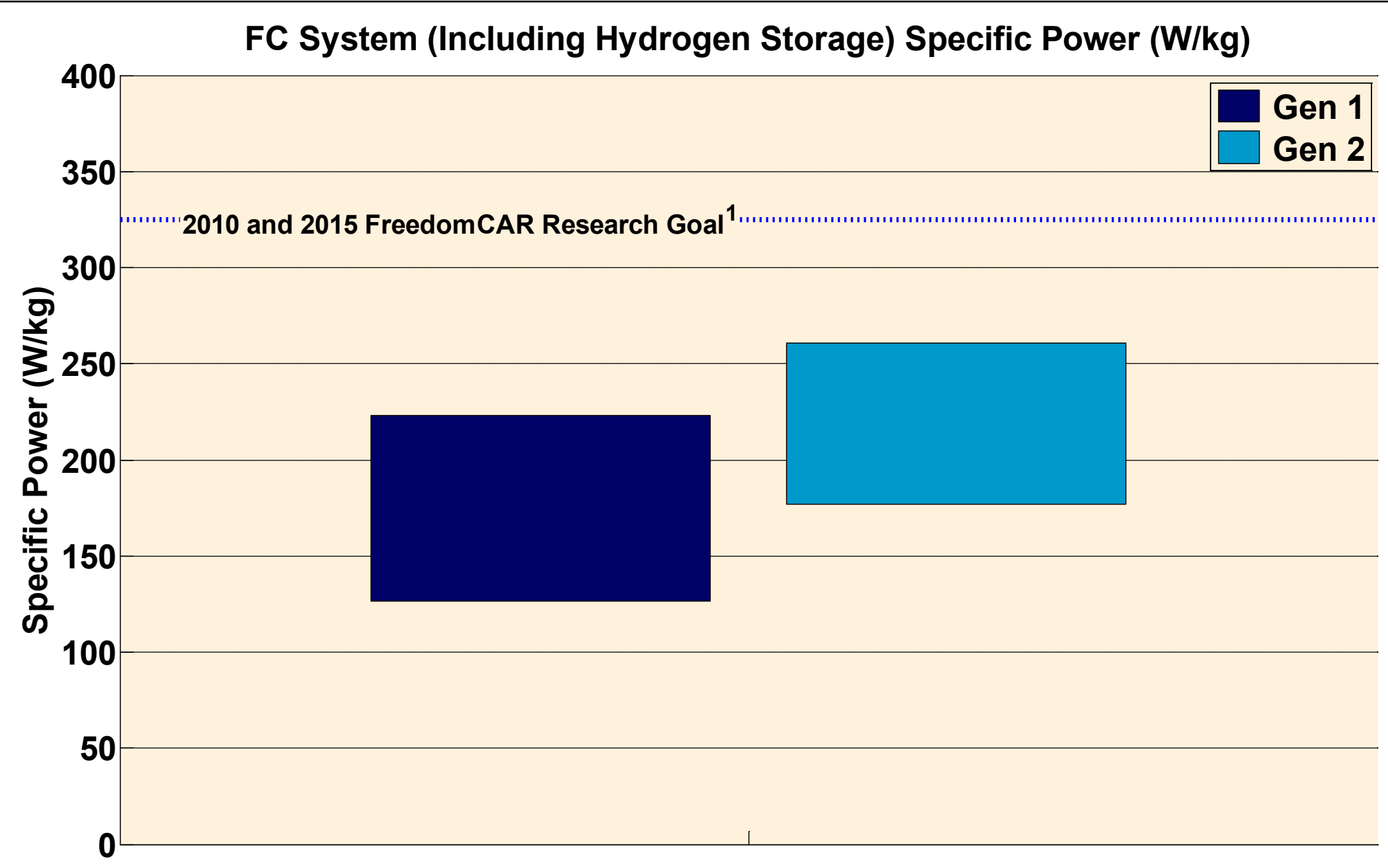




\section{CDP\#5: Fuel Cell Start Times from Sub-Freezing Soak Conditions}

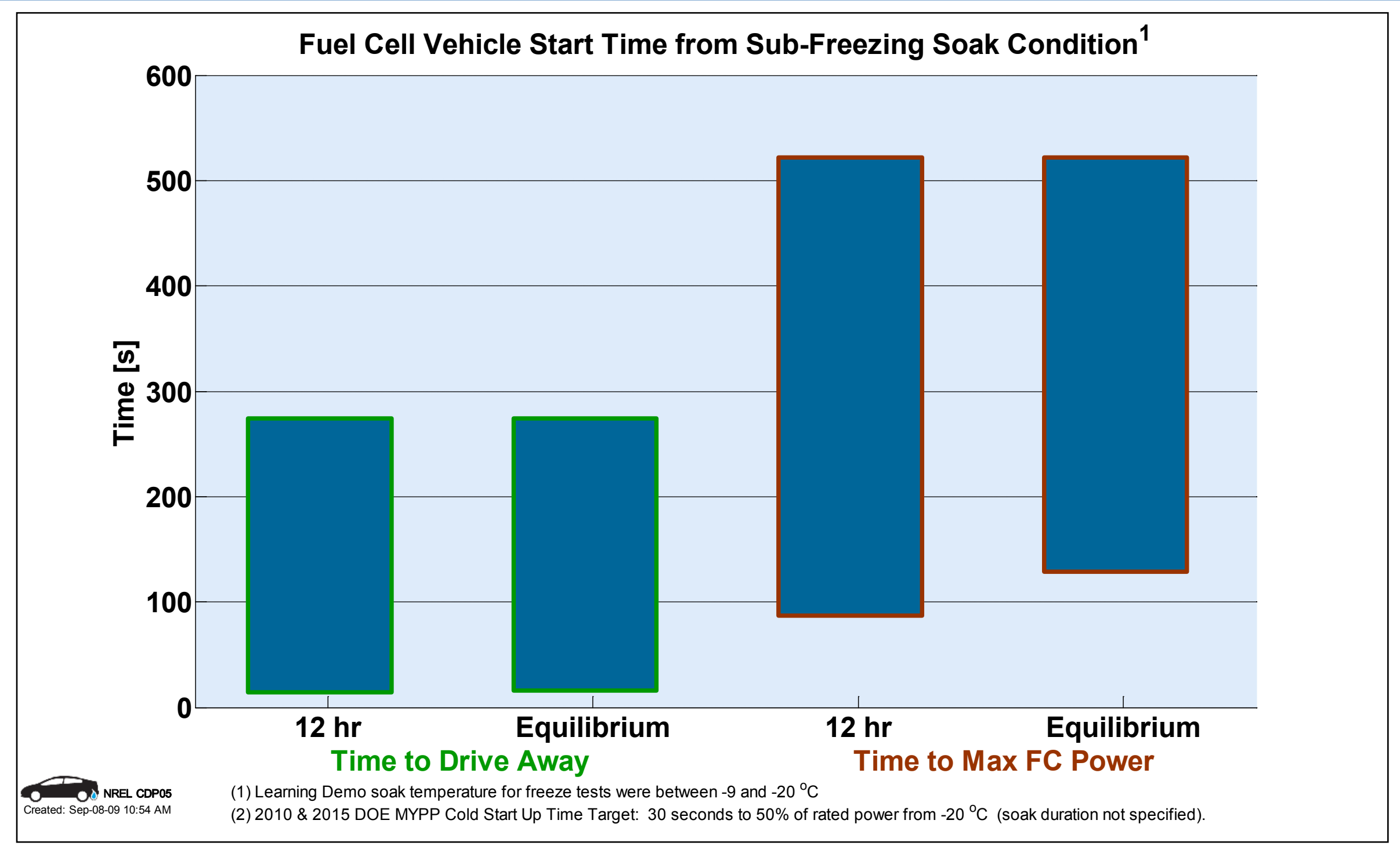




\section{CDP\#6: Fuel Economy}

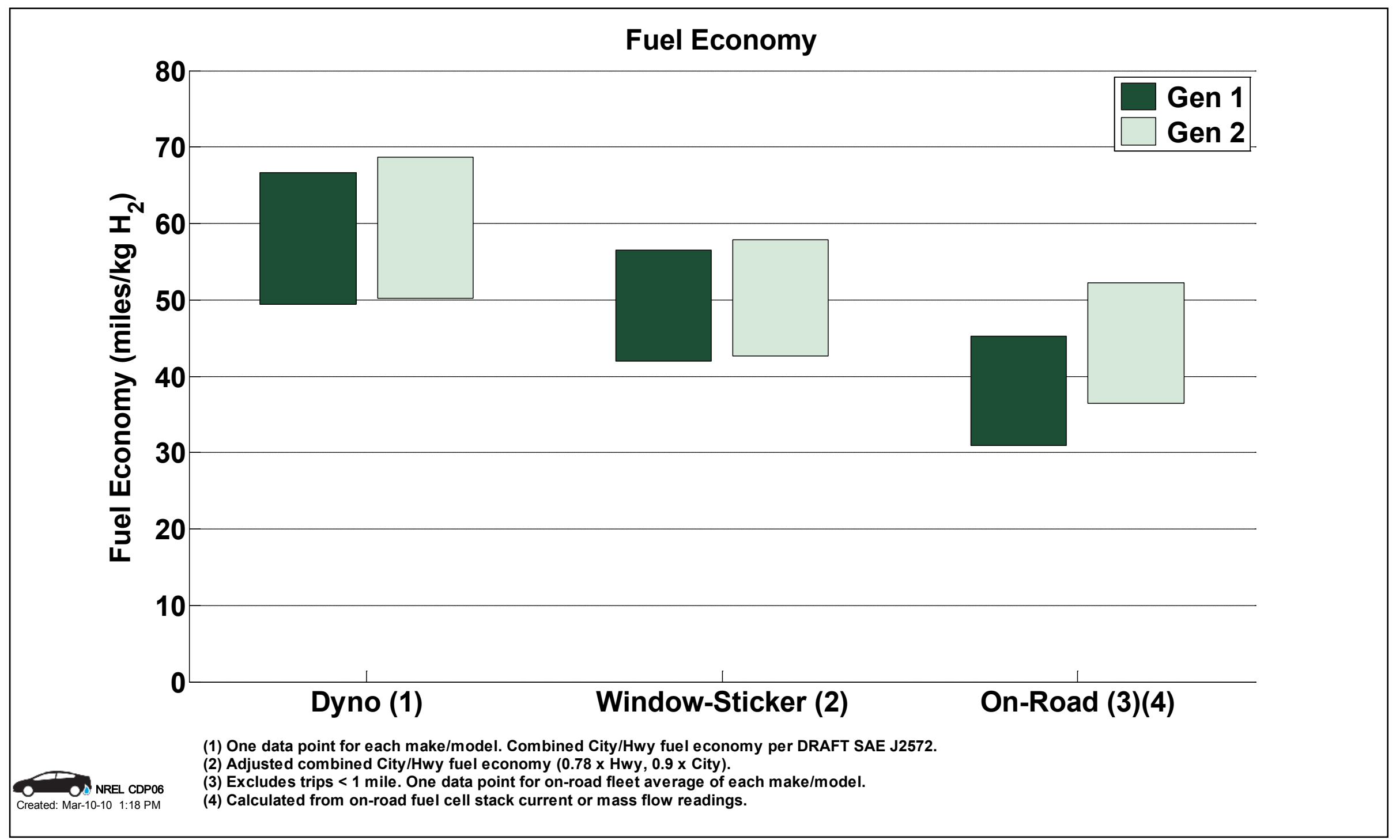




\section{CDP\#7: Fuel Cell Voltage}

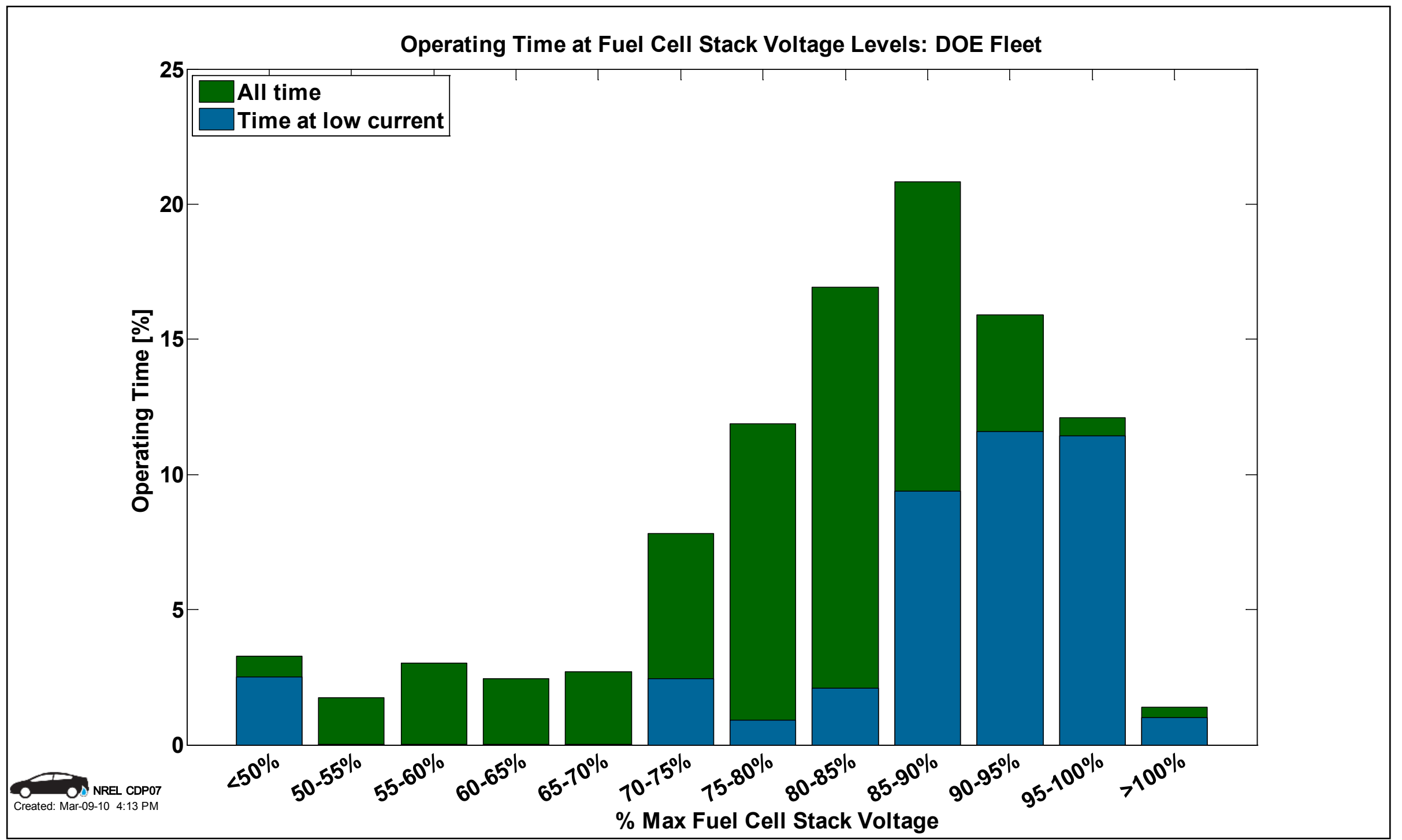




\section{CDP\#8: FC System Efficiency}

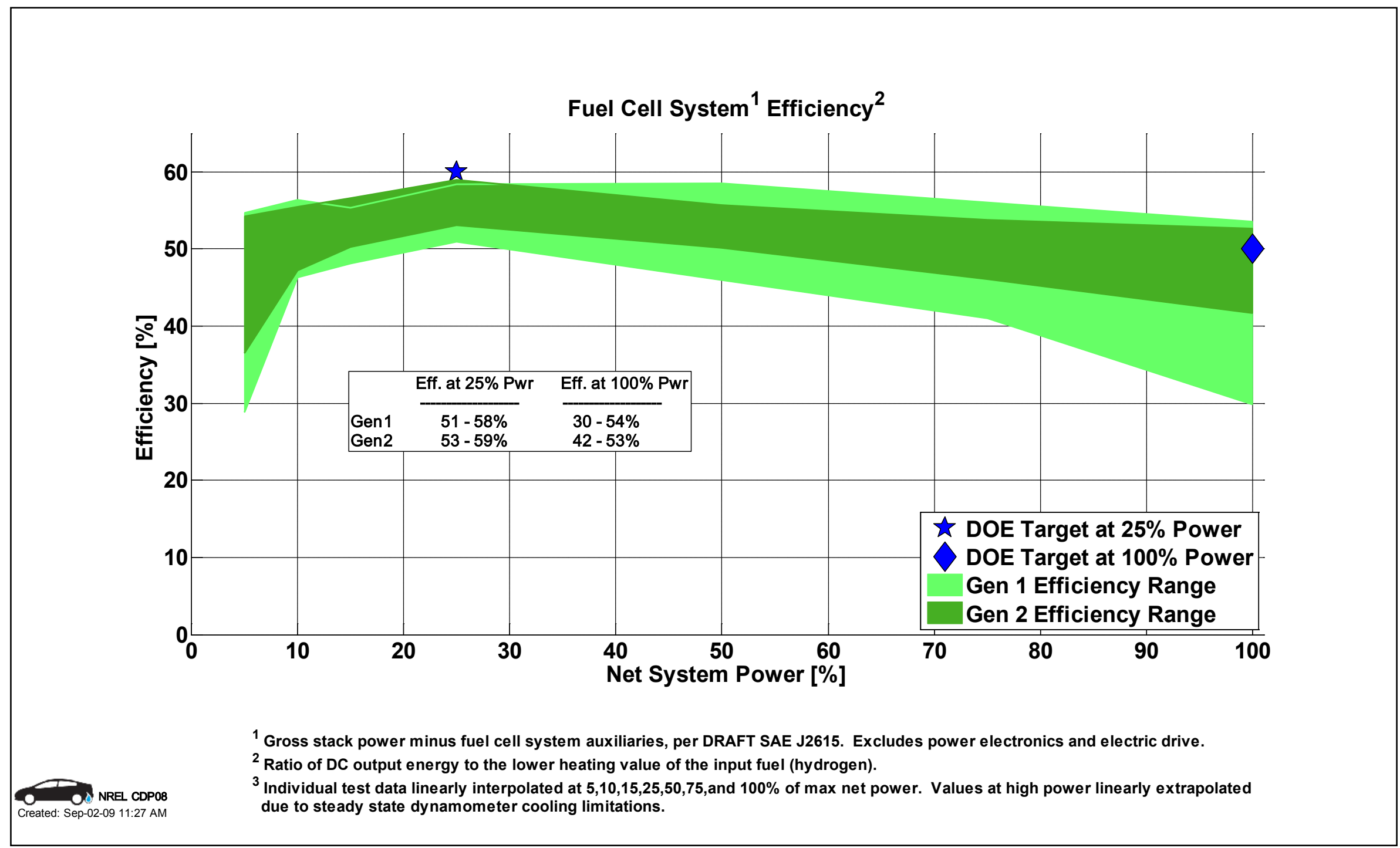




\section{CDP\#9: Safety Reports - Vehicles}

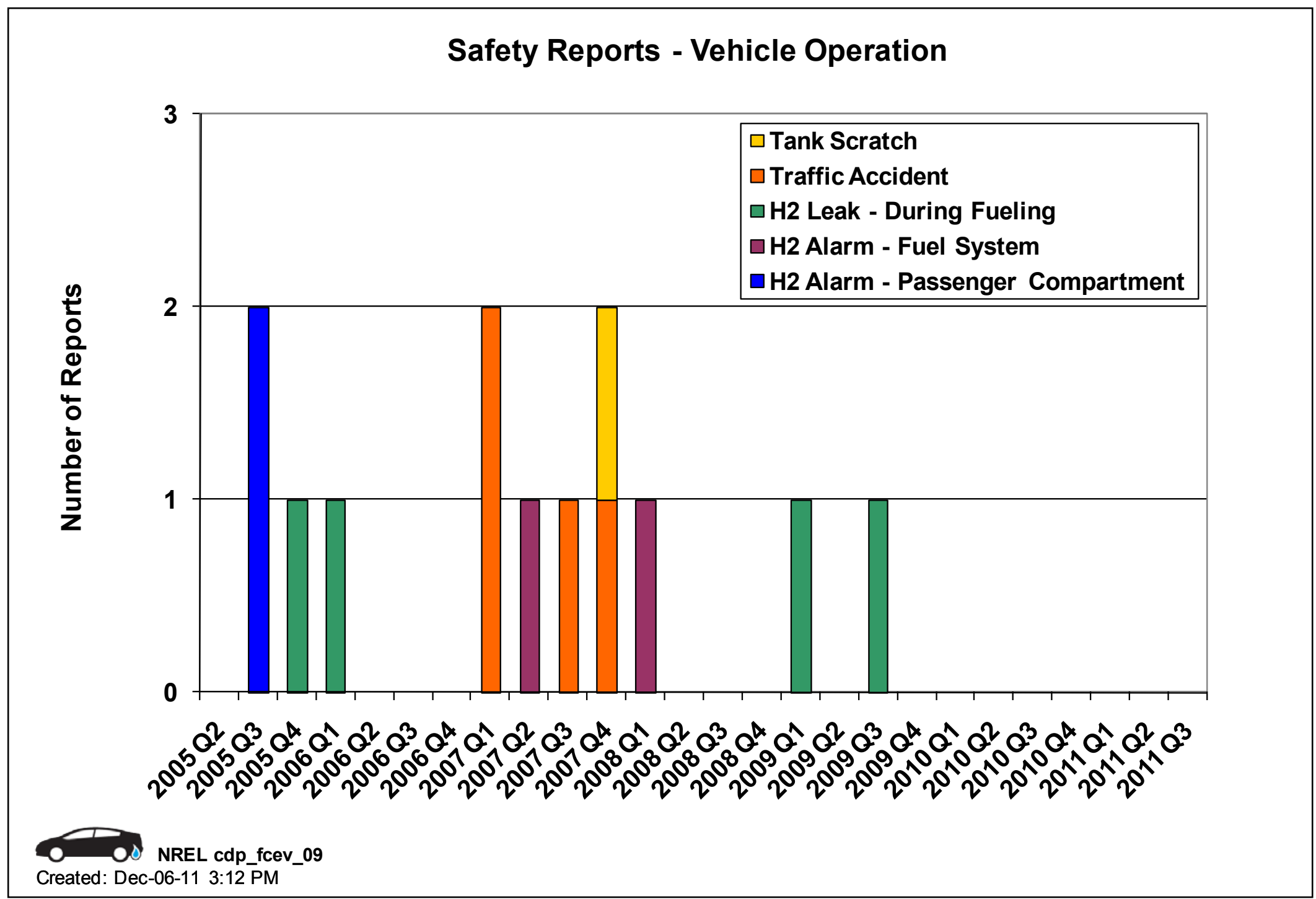




\section{CDP\#10: Storage Weight \% Hydrogen}

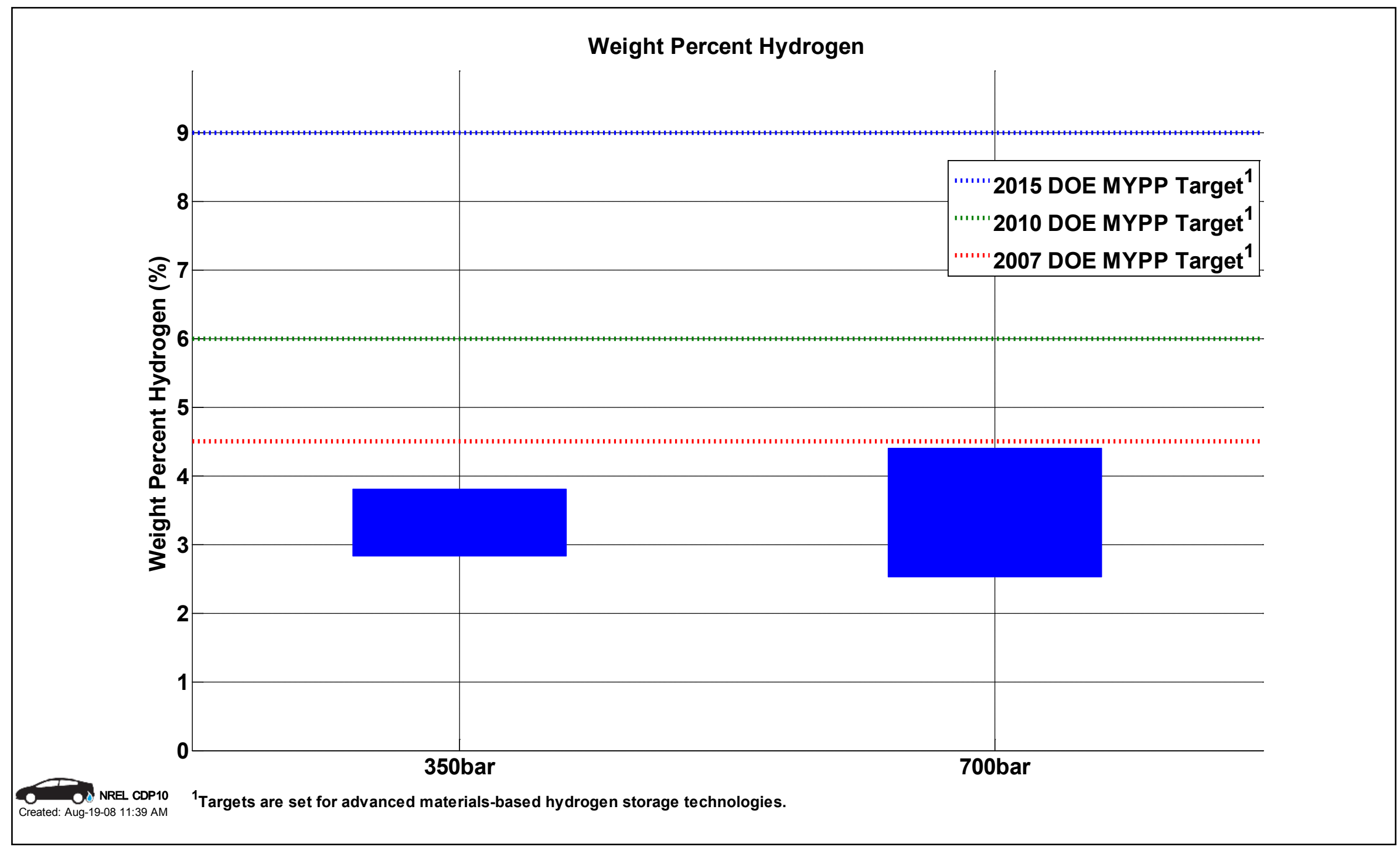




\section{CDP\#11: Volumetric Capacity of H2 Storage}

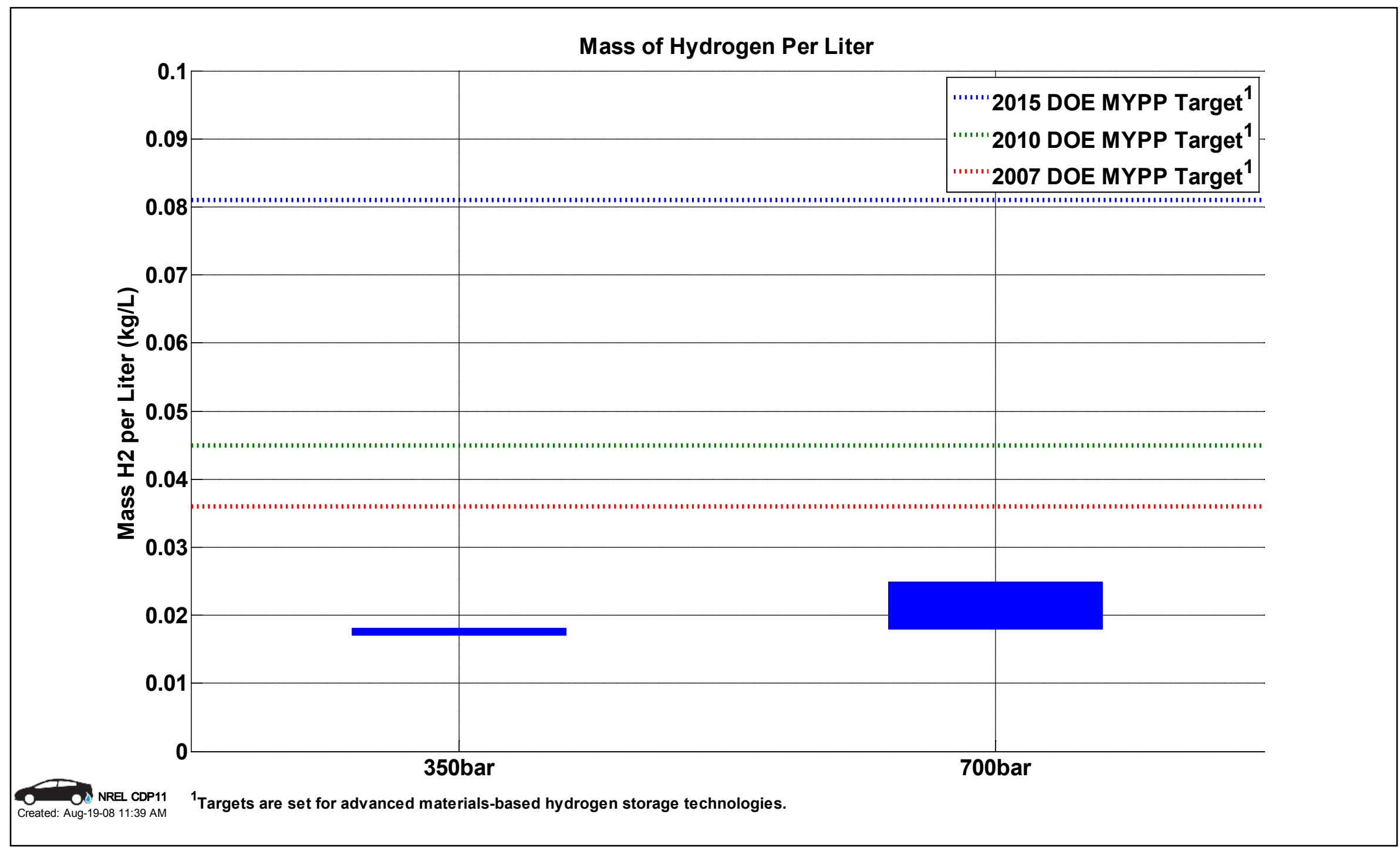




\section{CDP\#12: Vehicle Hydrogen Tank Cycle Life}

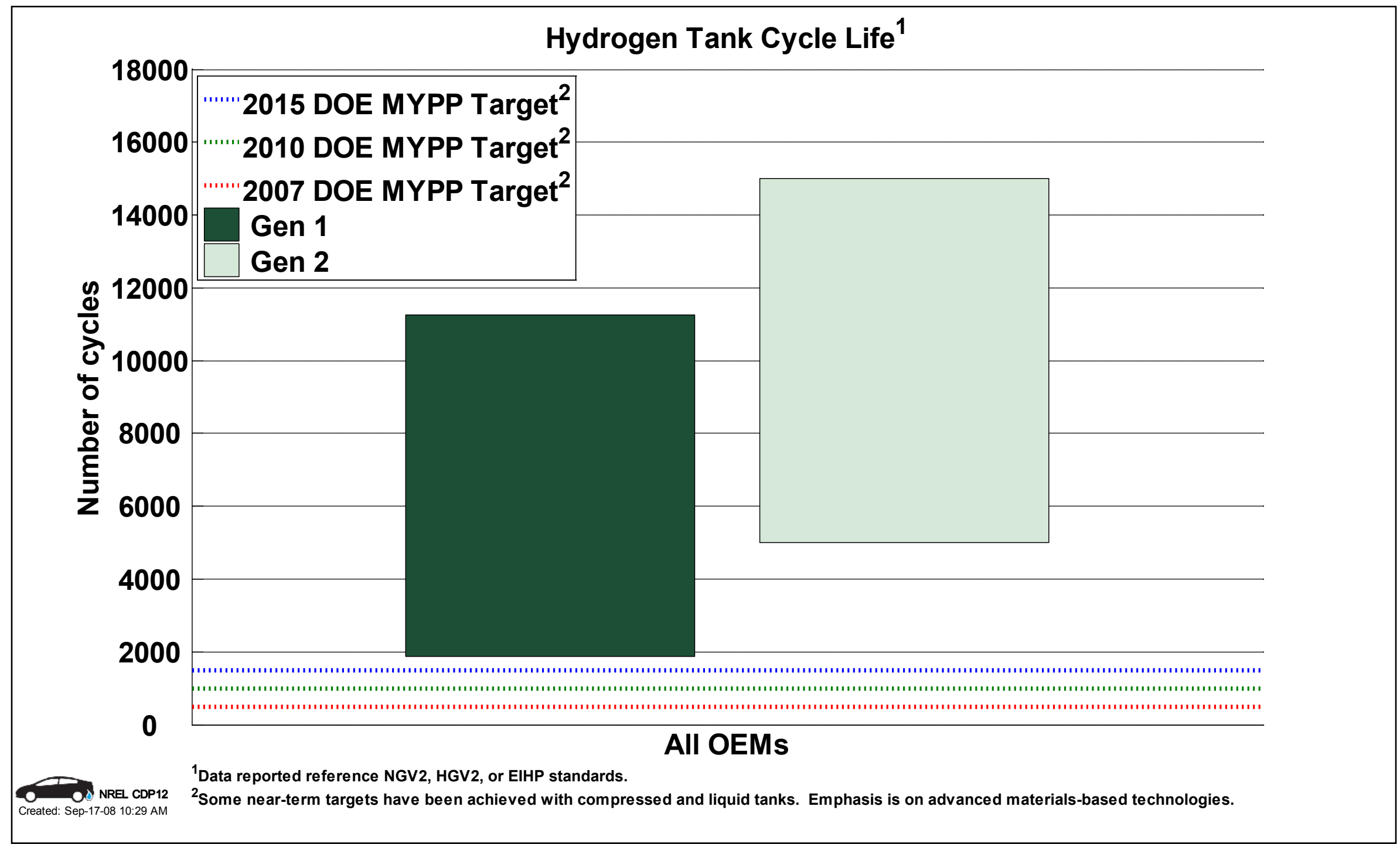




\section{CDP\#13: On-Site Hydrogen Production Efficiency}

Hydrogen Production Conversion Efficiency ${ }^{1}$

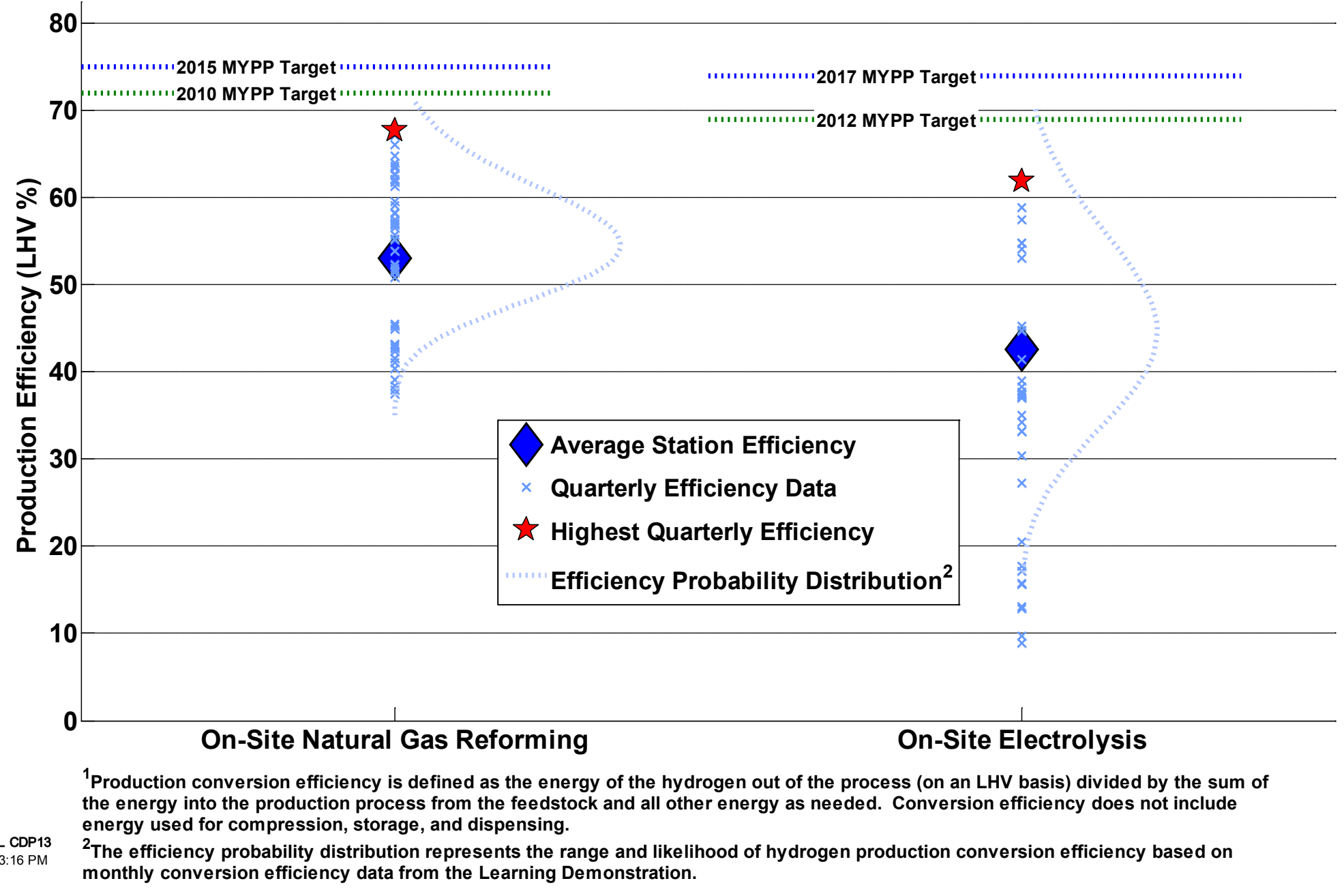




\section{CDP\#14: Fueling Rates by Fill Pressure}

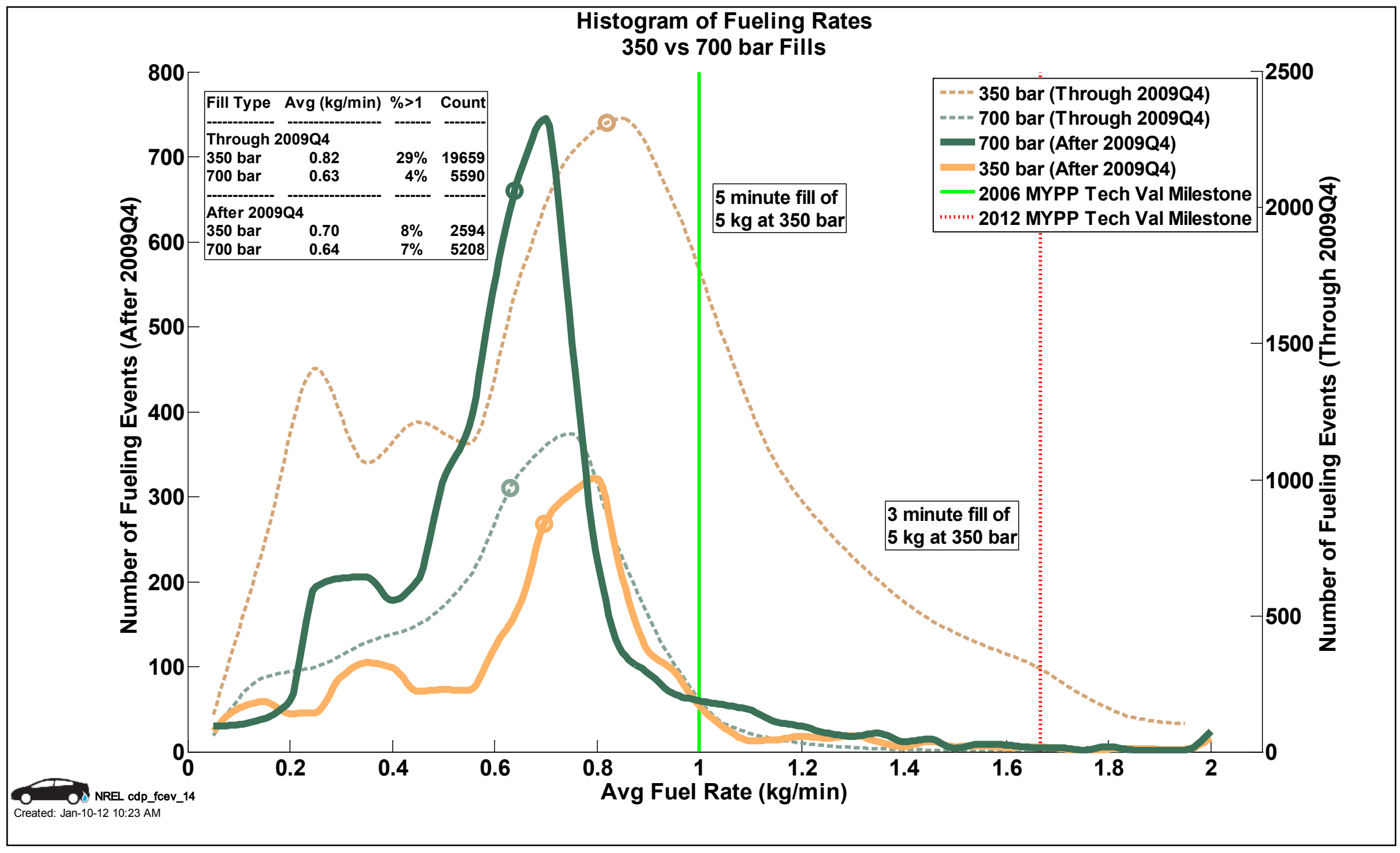




\section{CDP\#15: H2 Production Cost vs. Process}

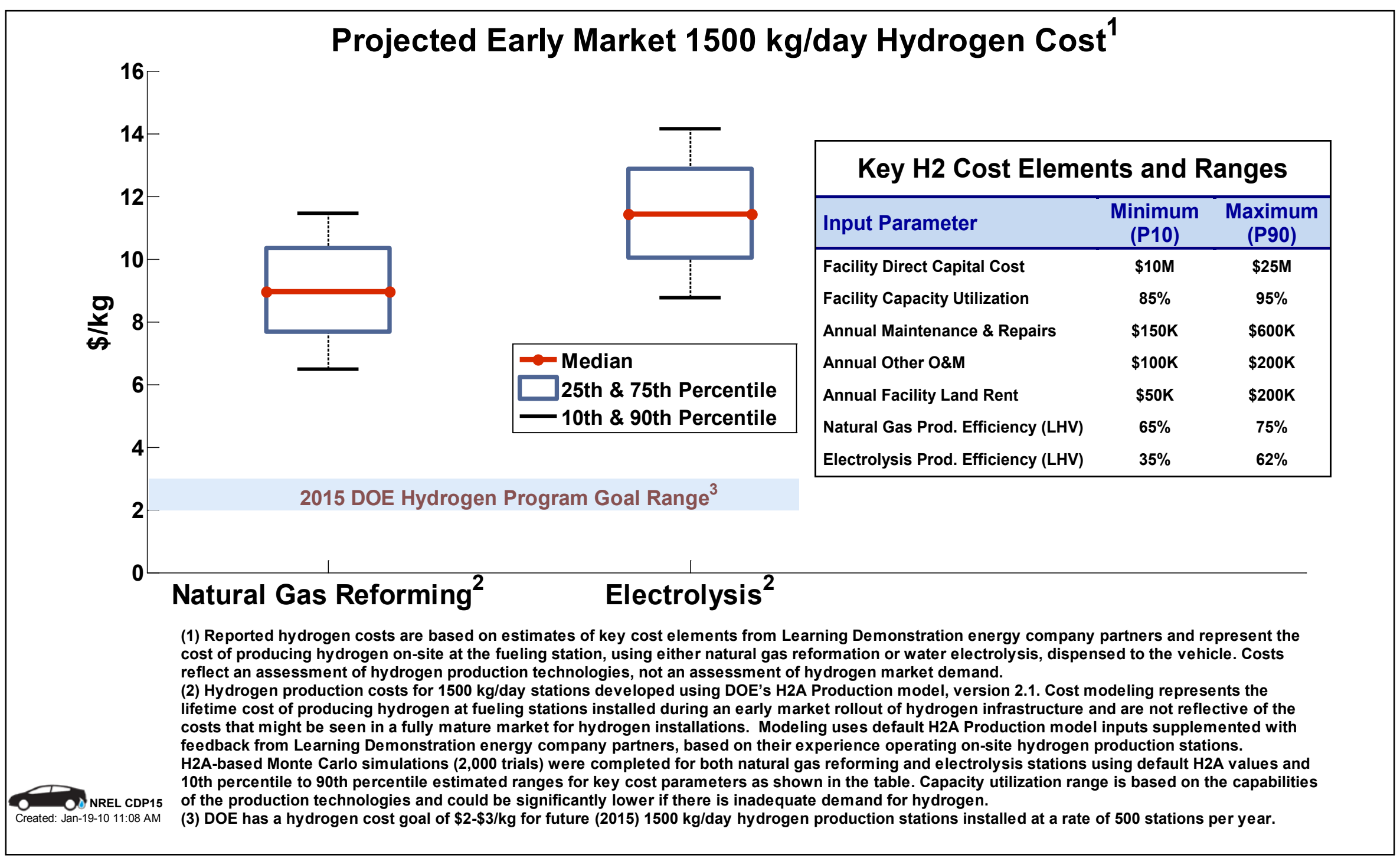




\section{CDP\#16: Fuel Cell Stack Trips Per Hour Histogram}

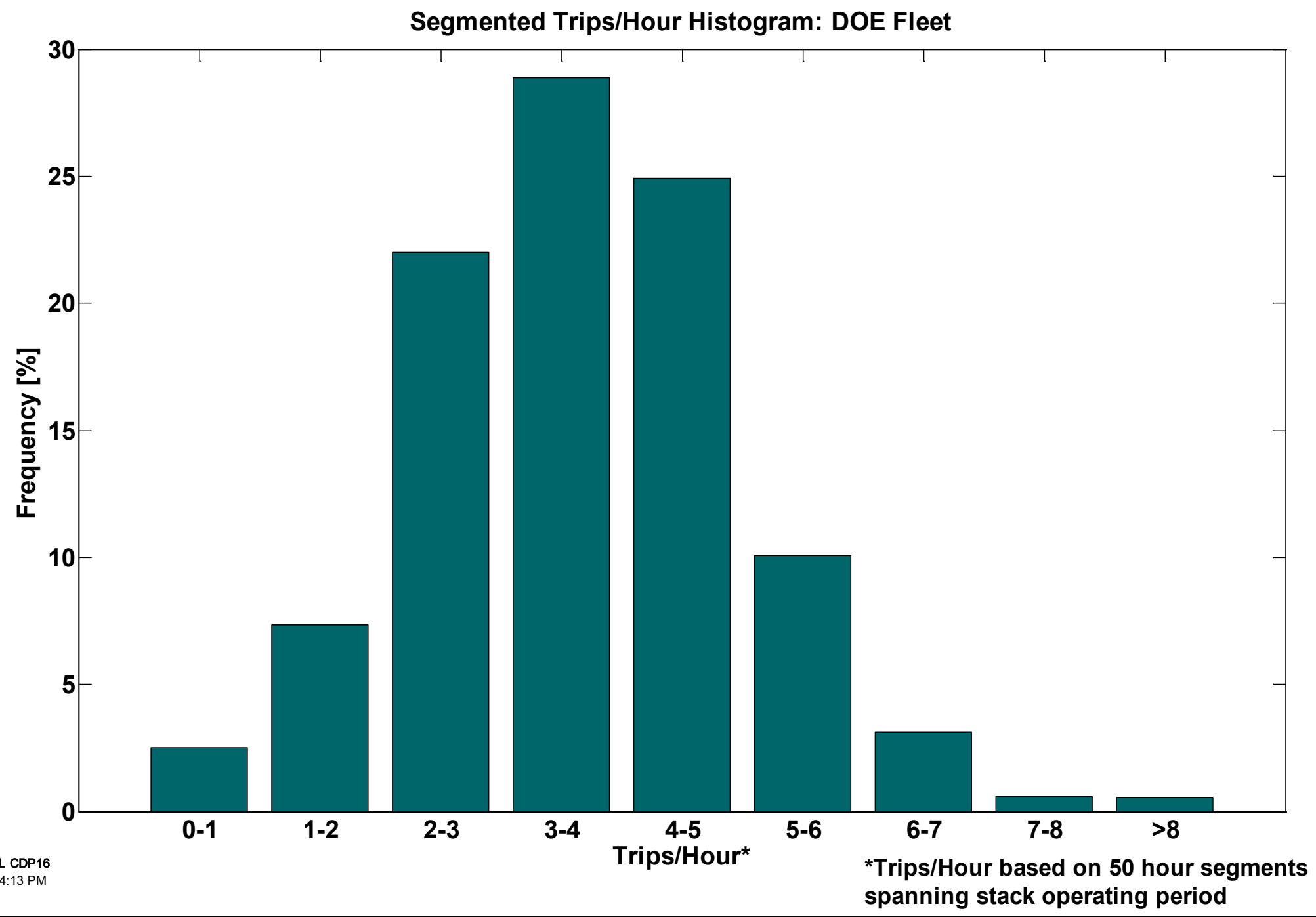




\section{CDP\#17: Statistics of Trips/Hour vs. Operating Hour}

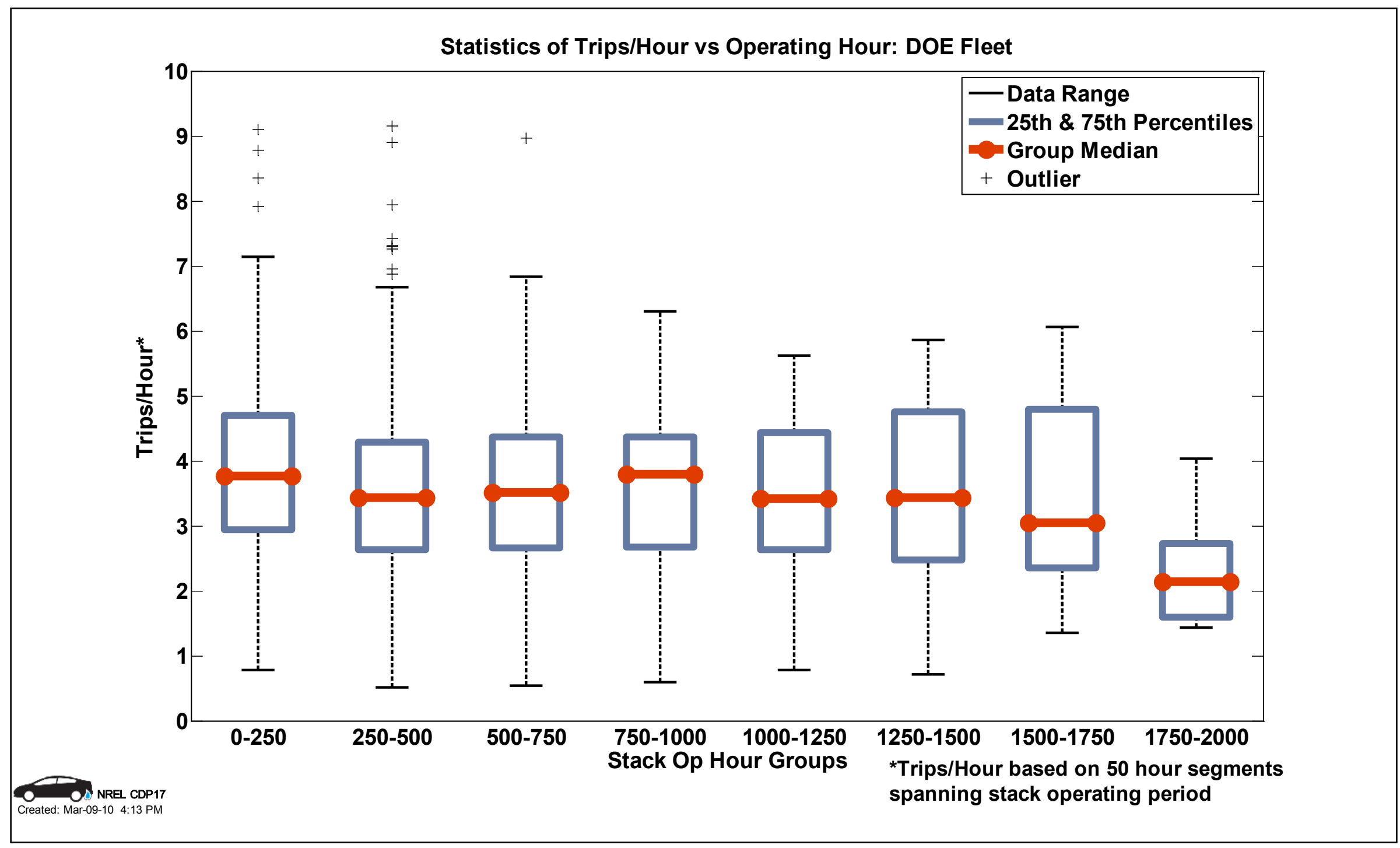




\section{CDP\#18: Refueling Rates}

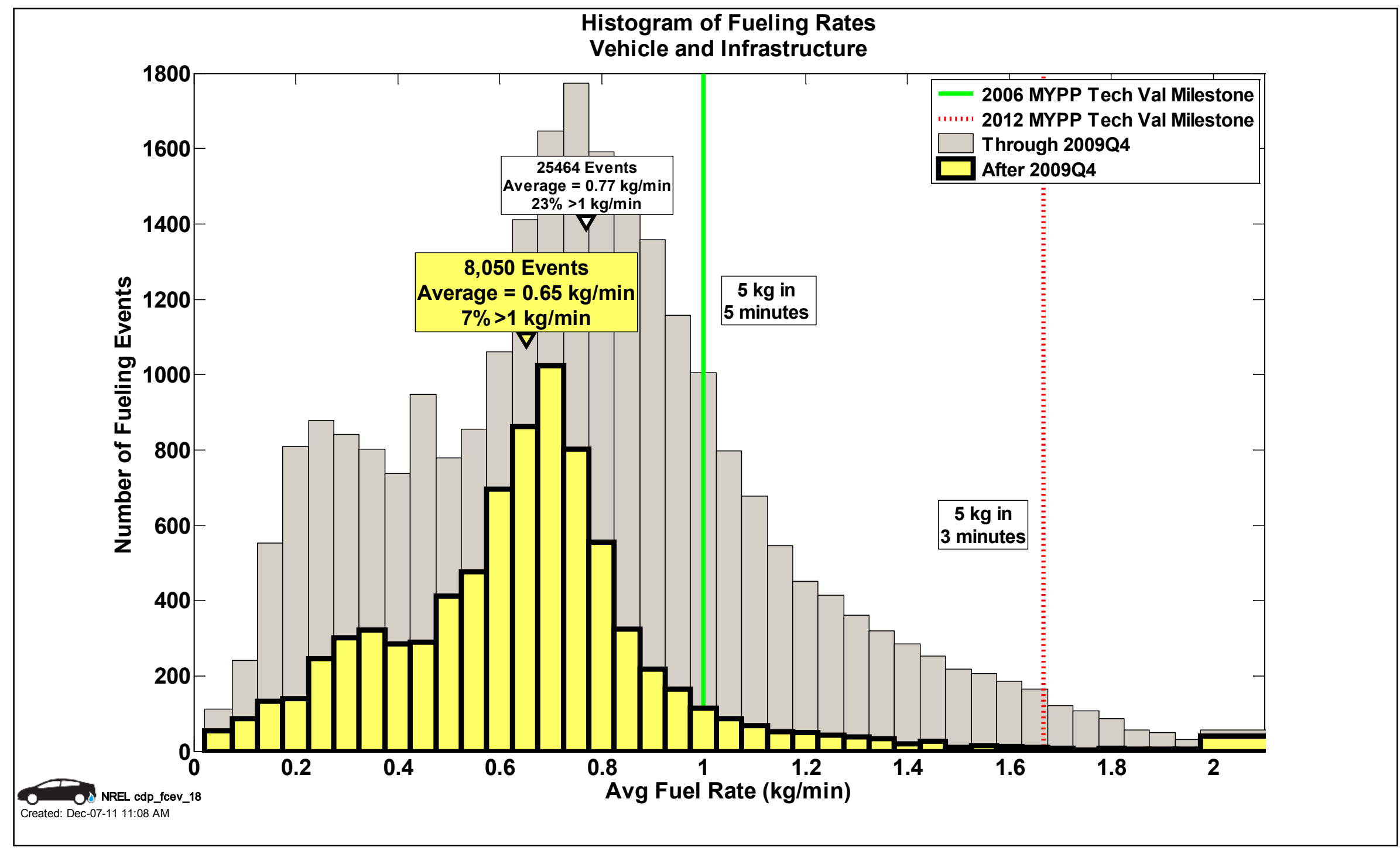




\section{CDP\#19: Time Between Trips \& Ambient Temperature}

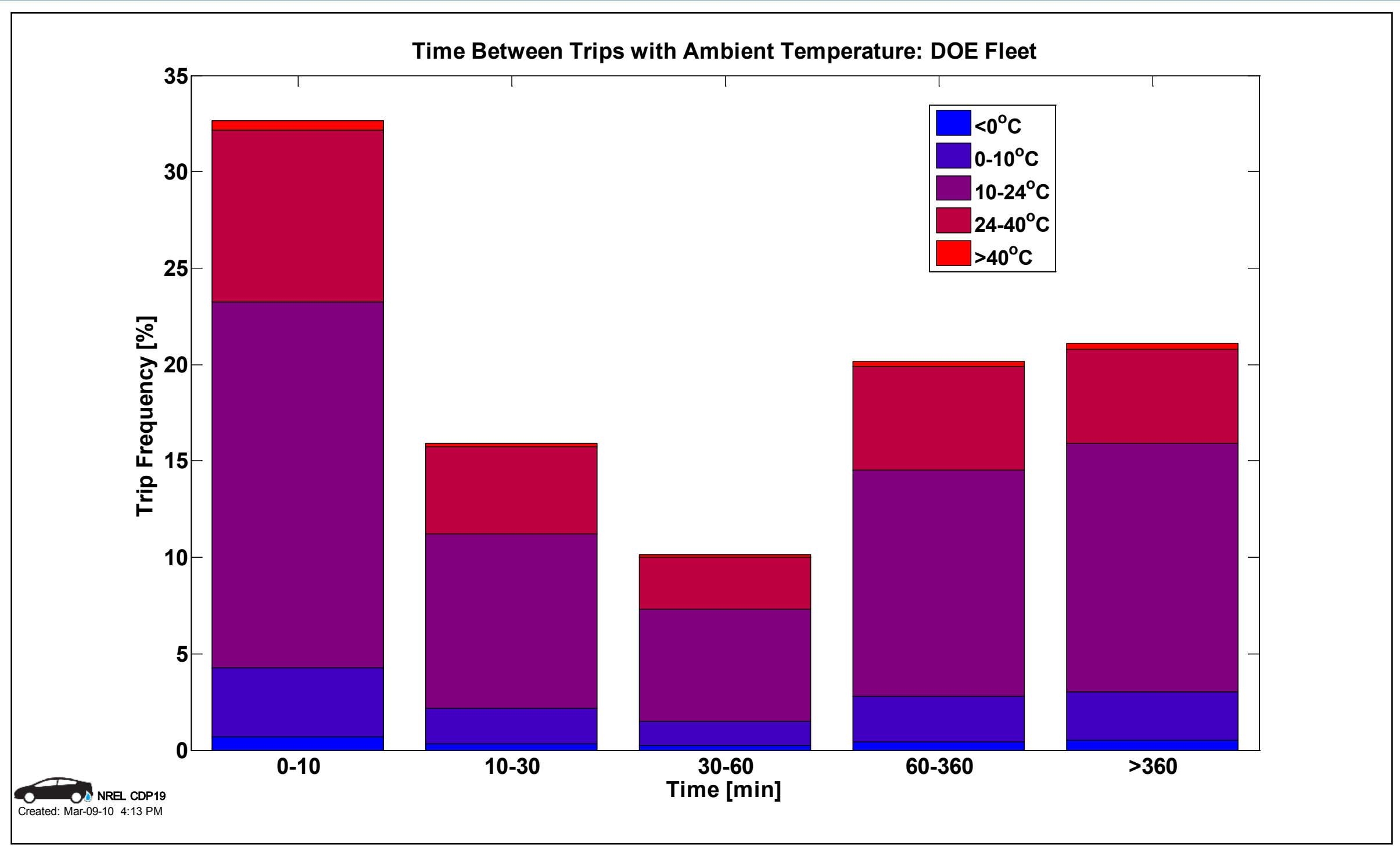




\section{CDP\#20: Safety Reports - Infrastructure}

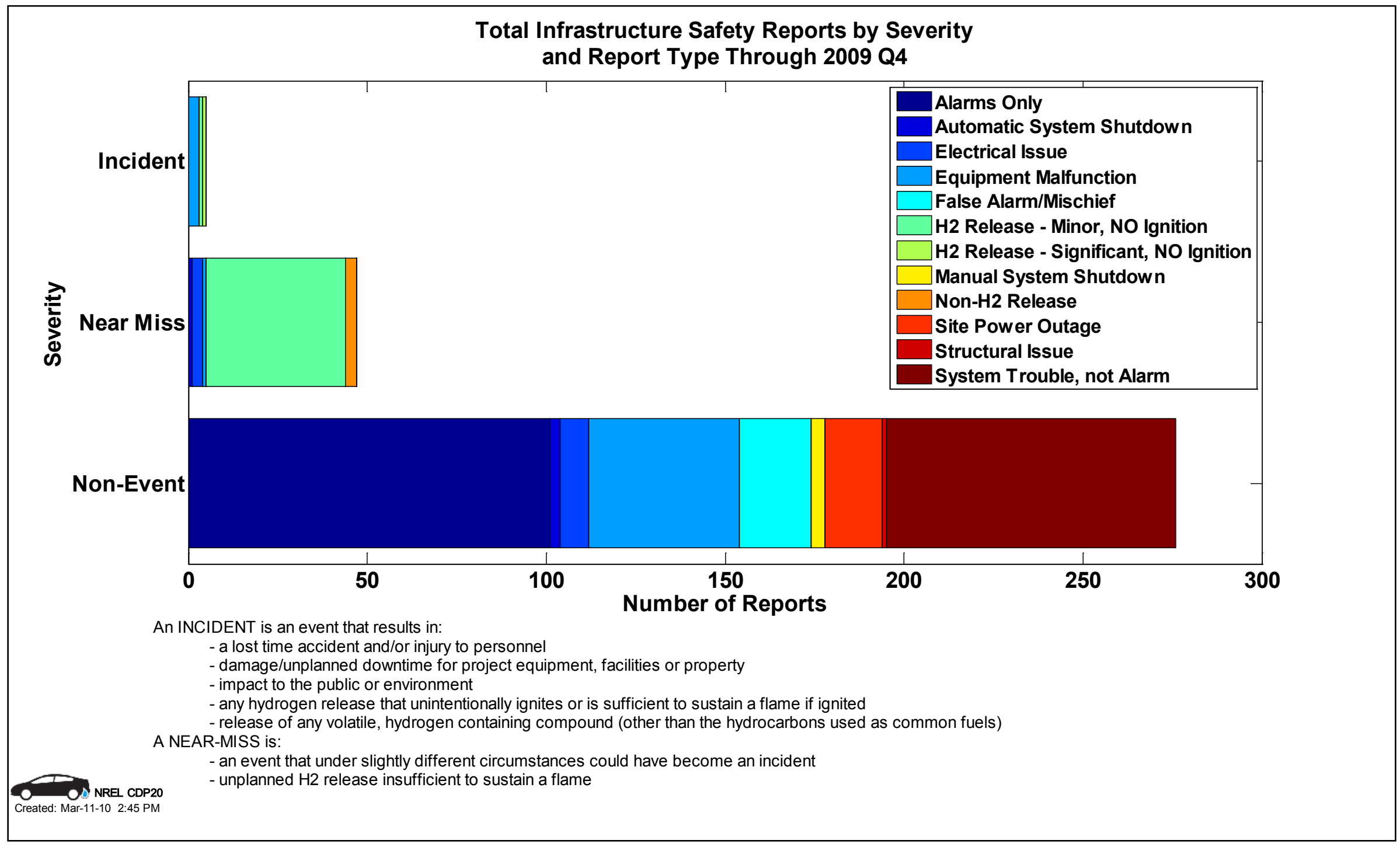




\section{CDP\#21: Range of Ambient Temperature During Vehicle Operation}

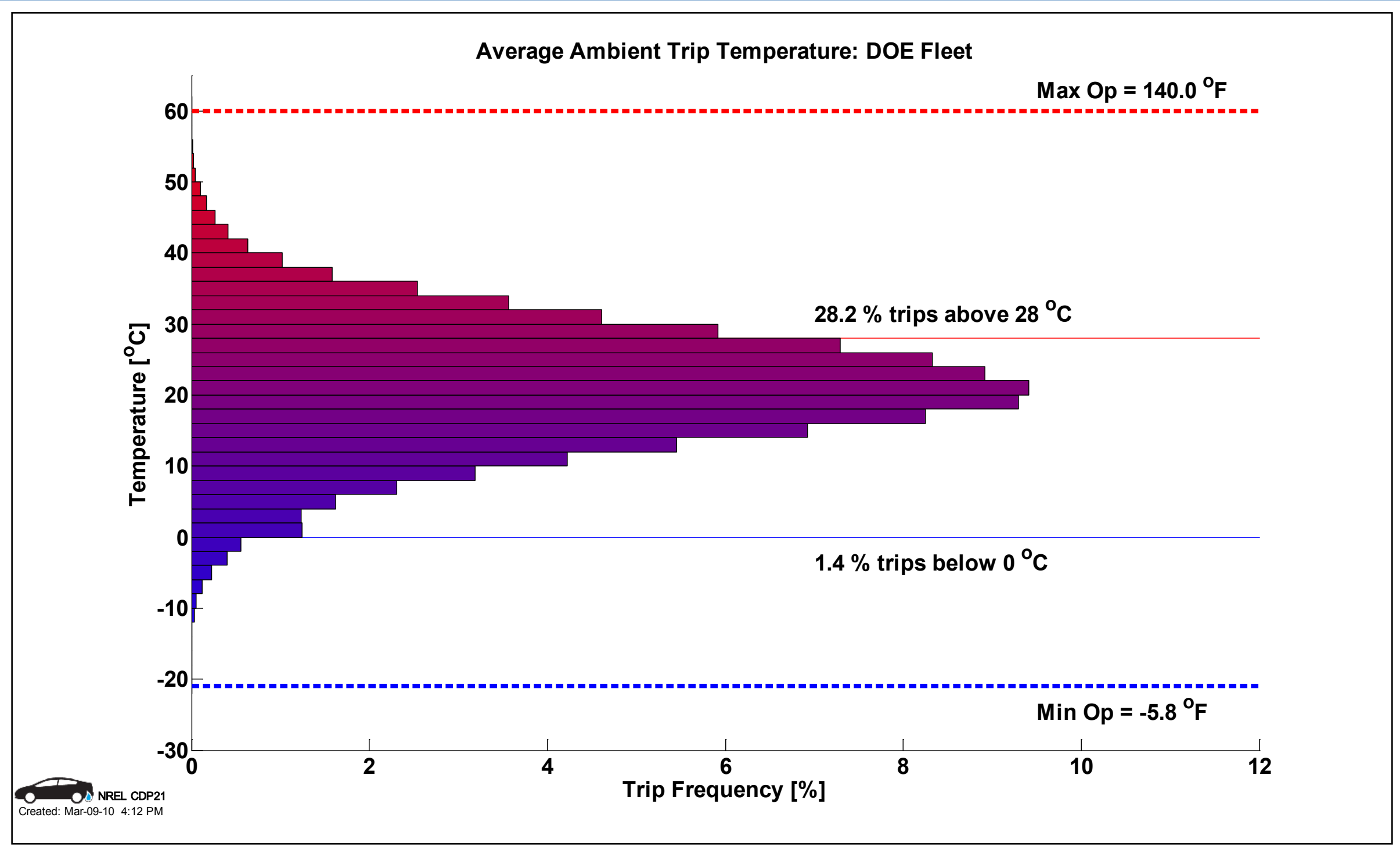




\section{CDP\#22: Vehicle Operating Hours}

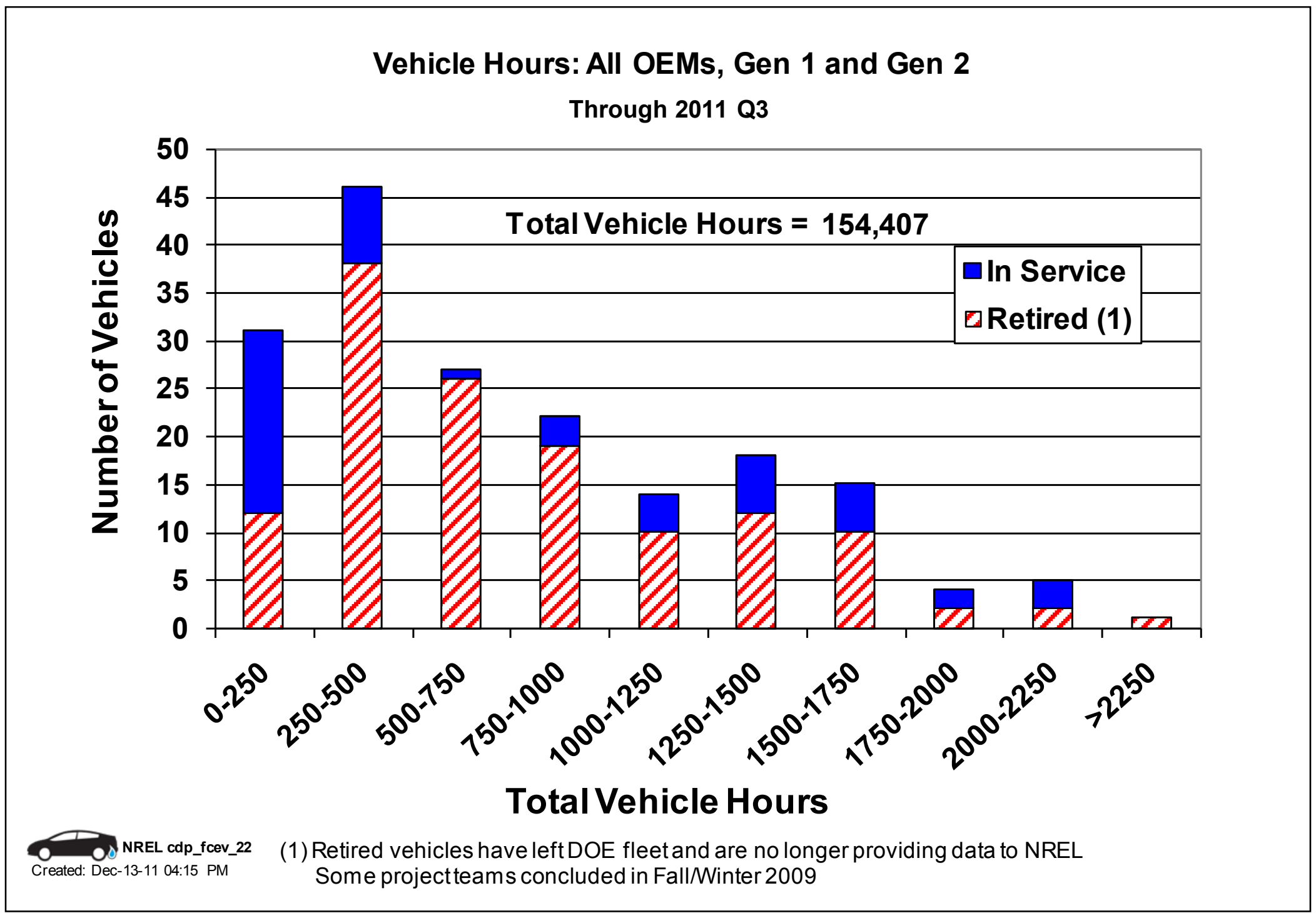




\section{CDP\#23: Vehicles vs. Miles Traveled}

Vehicle Miles: All OEMs, Gen 1 and 2

Through 2011 Q3

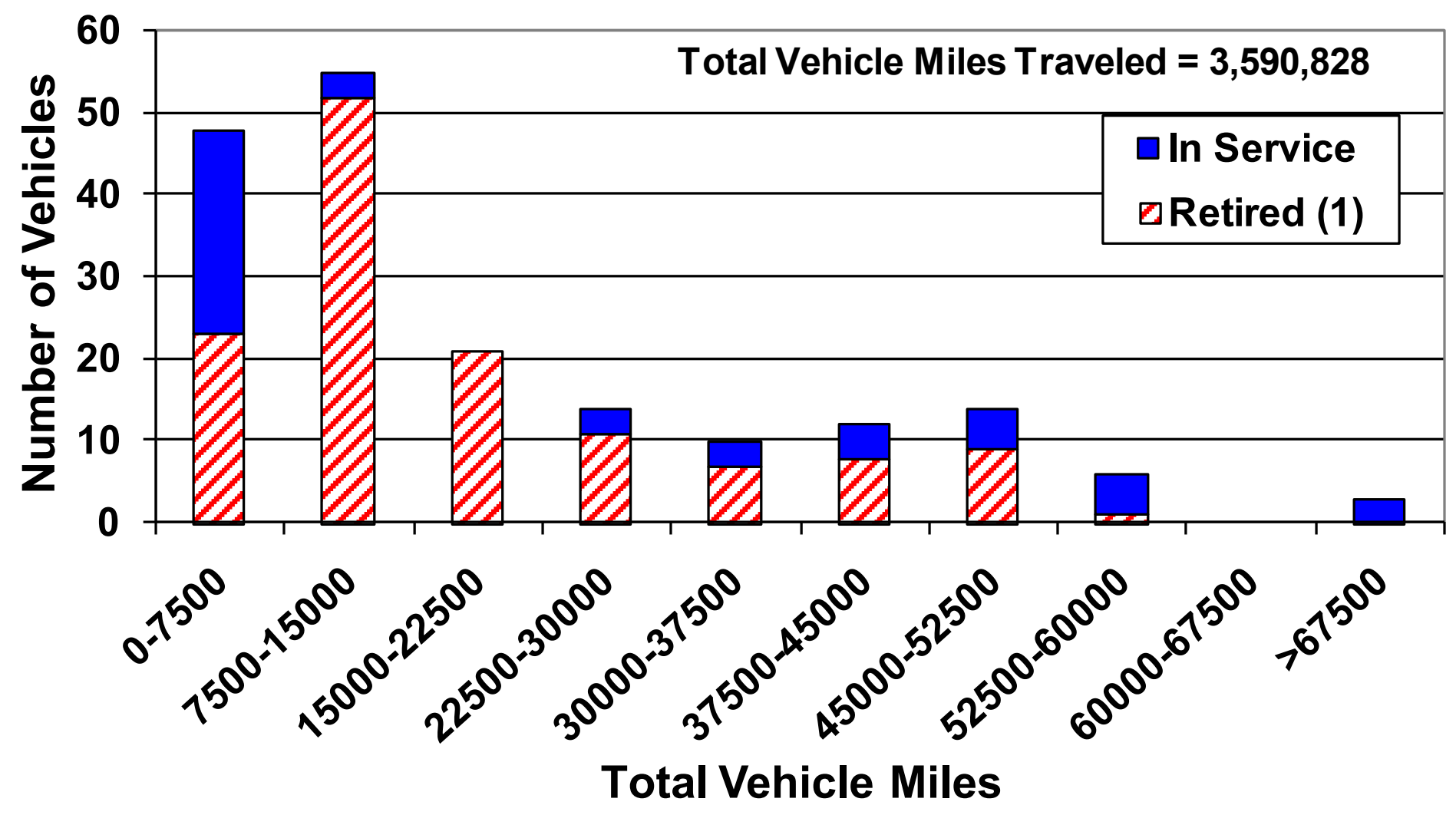

(1) Retired vehicles have left DOE fleet and are no longer providing data to NREL 


\section{CDP\#24: Cumulative Vehicle Miles Traveled}

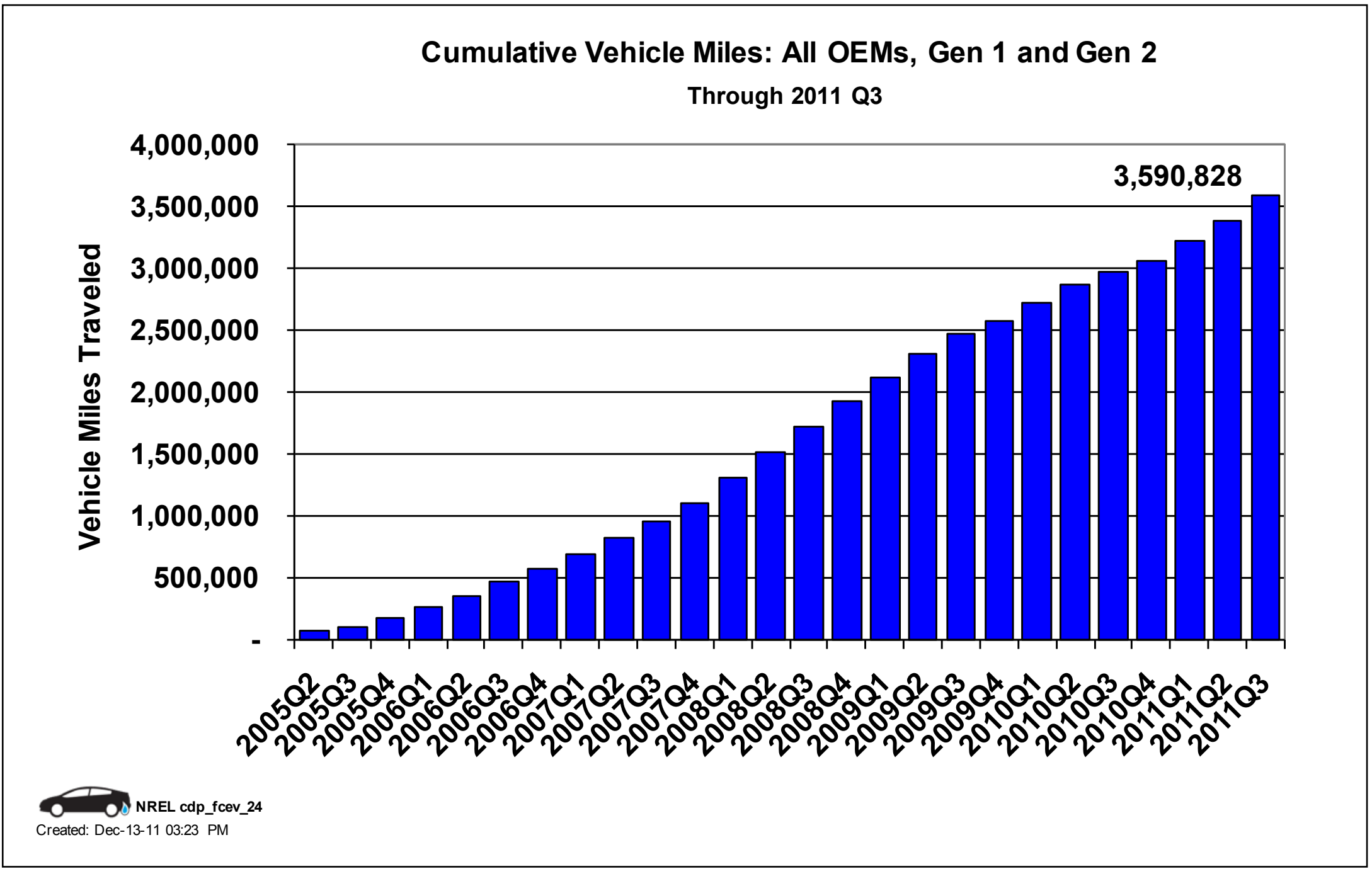




\section{CDP\#25: Vehicle H2 Storage Technologies}

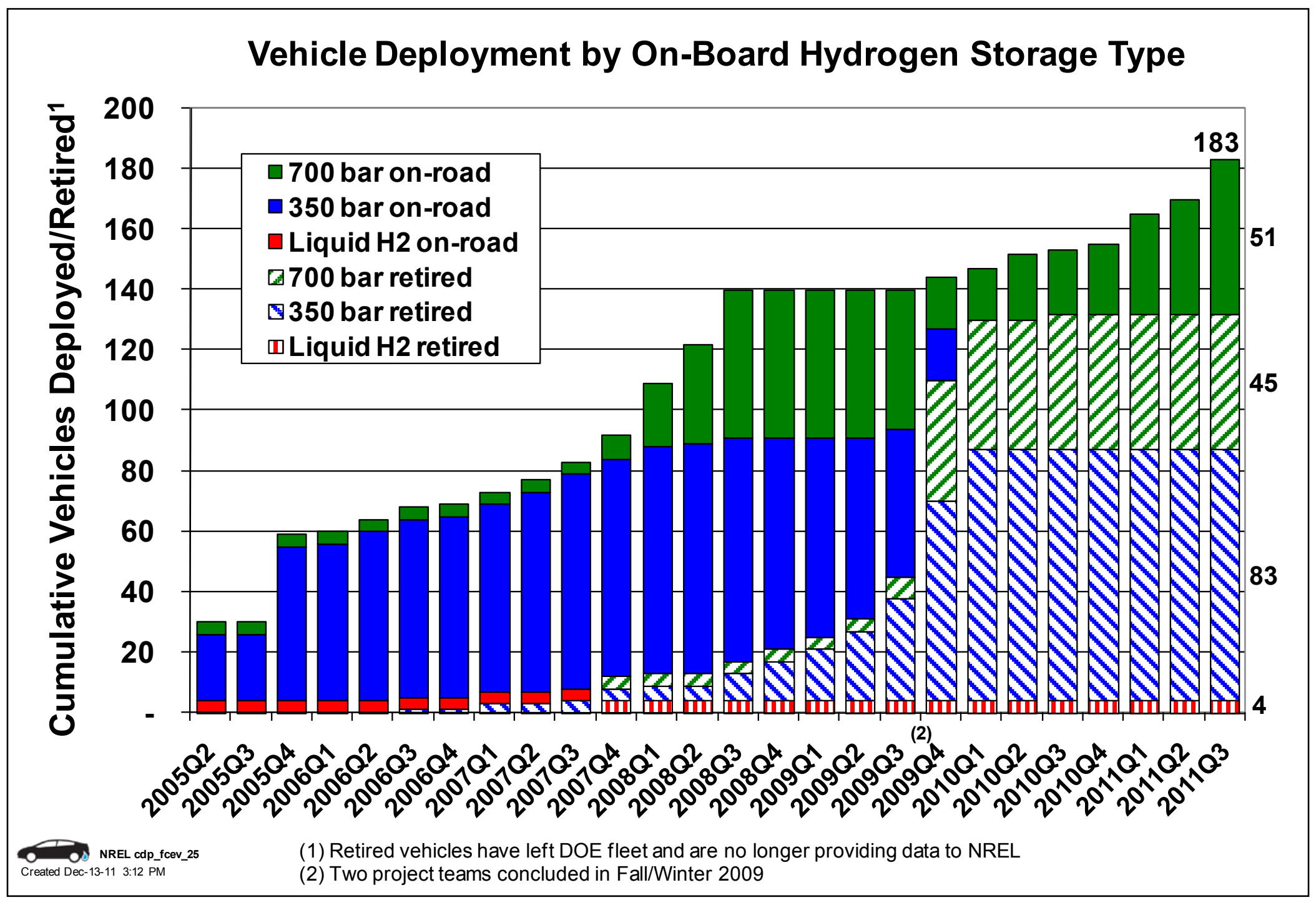




\section{CDP\#26: Cumulative H2 Produced or Dispensed}

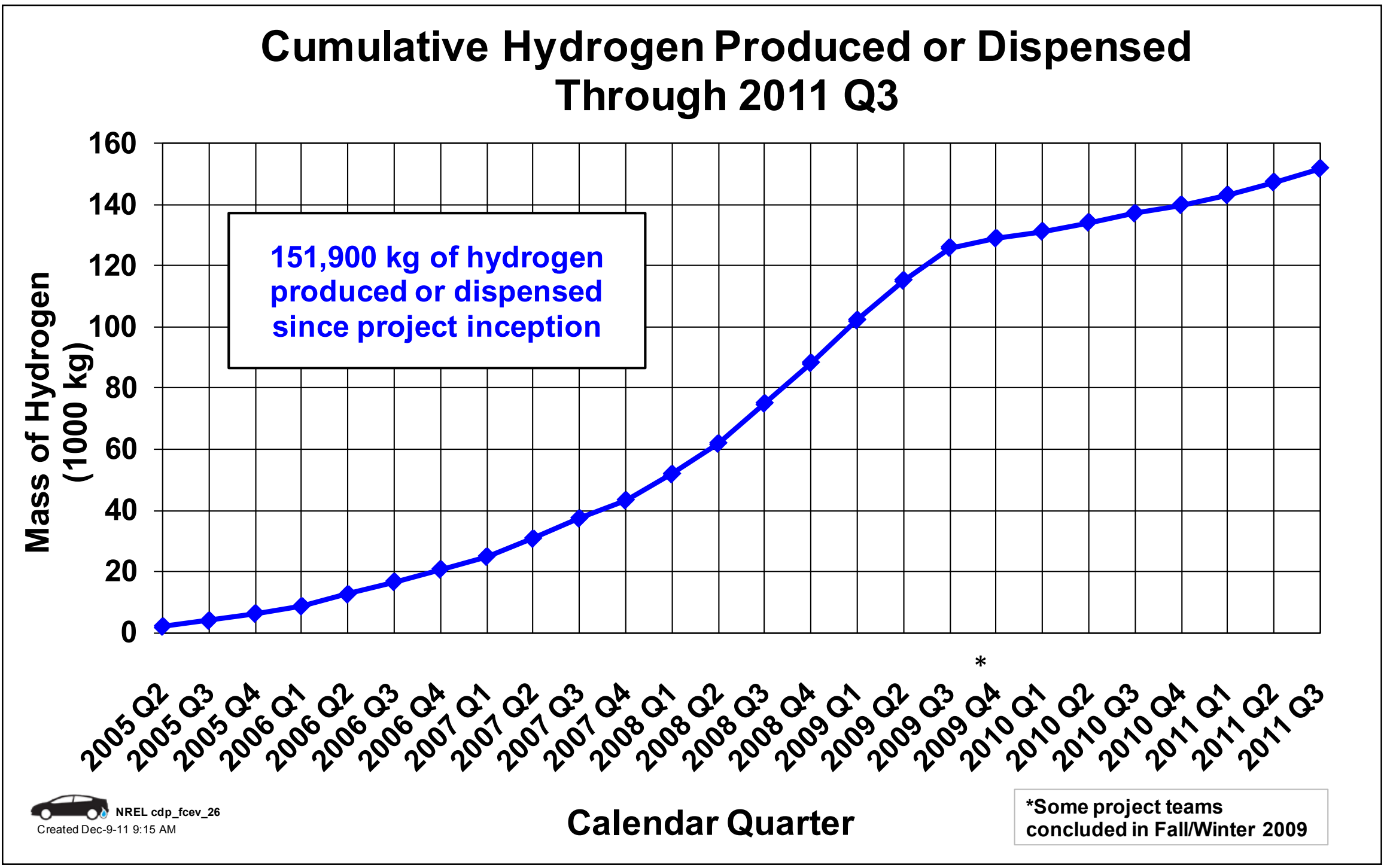




\section{CDP\#27: Hydrogen Quality Index}

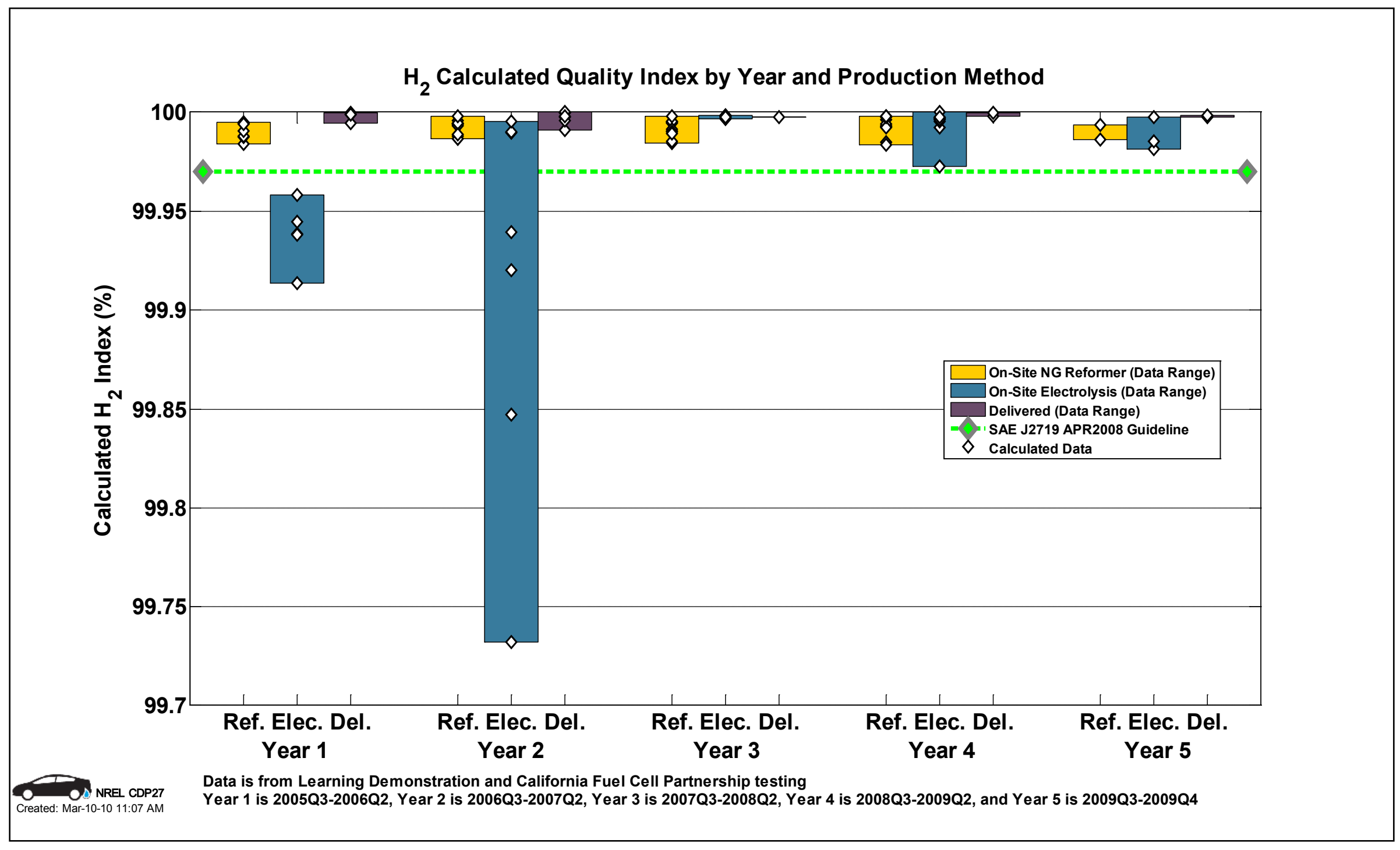




\section{CDP\#28: Hydrogen Fuel Constituents}

\section{$\mathrm{H}_{2}$ Fuel Constituents}
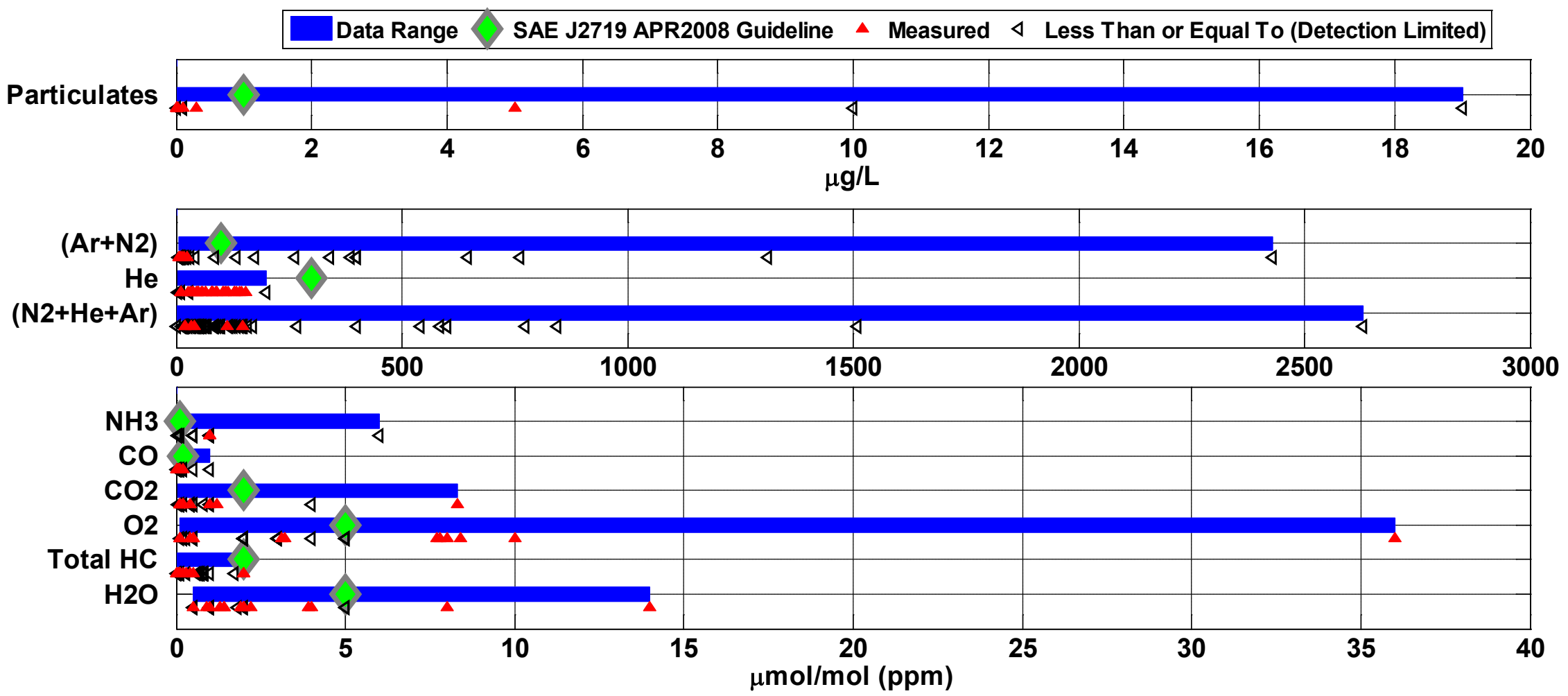

Total S*

\begin{tabular}{|l|l|l|l|l|l|l|}
\hline & & & & & \\
\hline
\end{tabular}




\section{CDP\#28 Supplemental: Hydrogen Constituents by Year and Production Method}

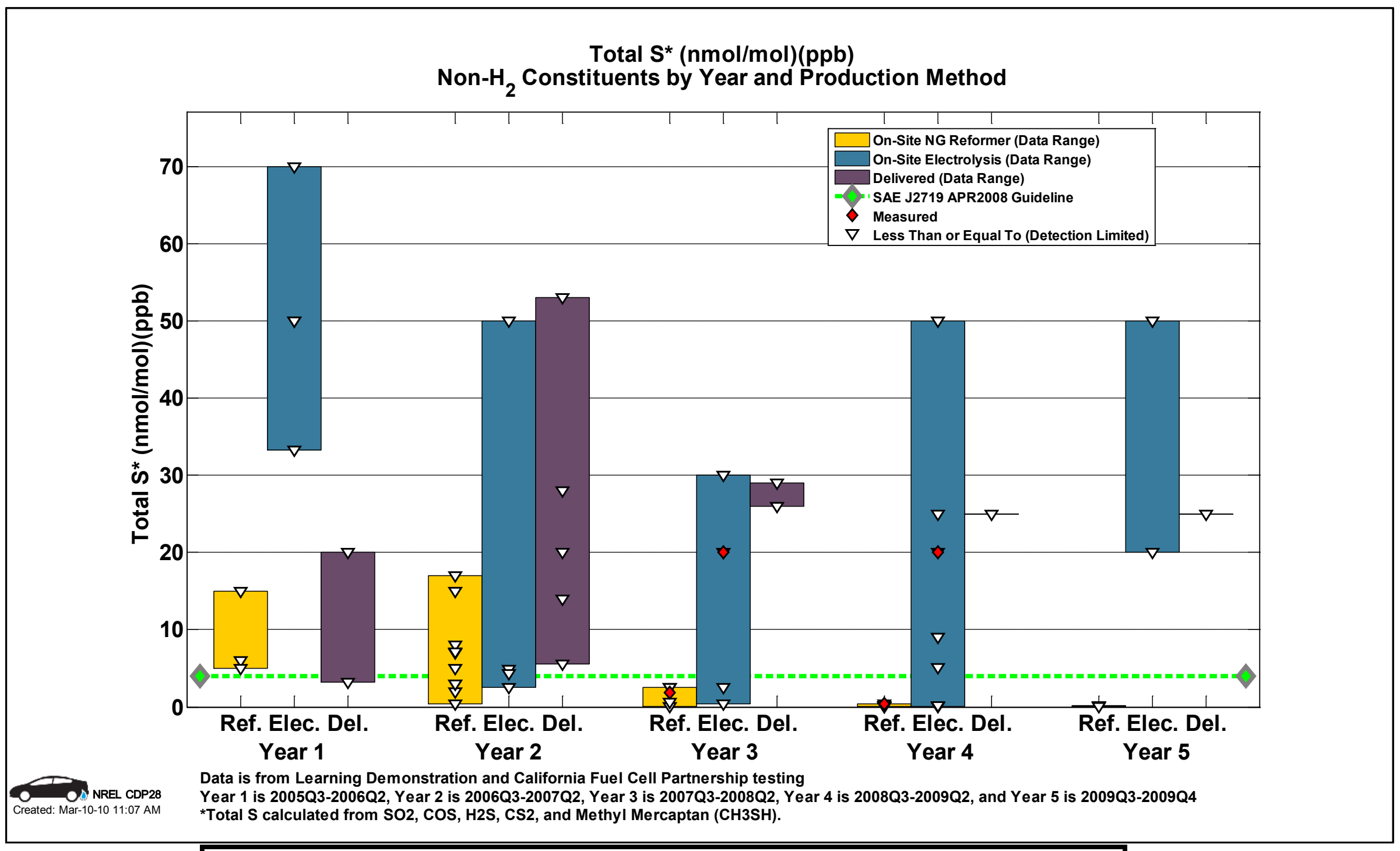

(This slide contains 18 graphs (1 for each constituent): view in slide-show mode) 


\section{CDP\#29: Fueling Rates by Communication}

\section{Type}

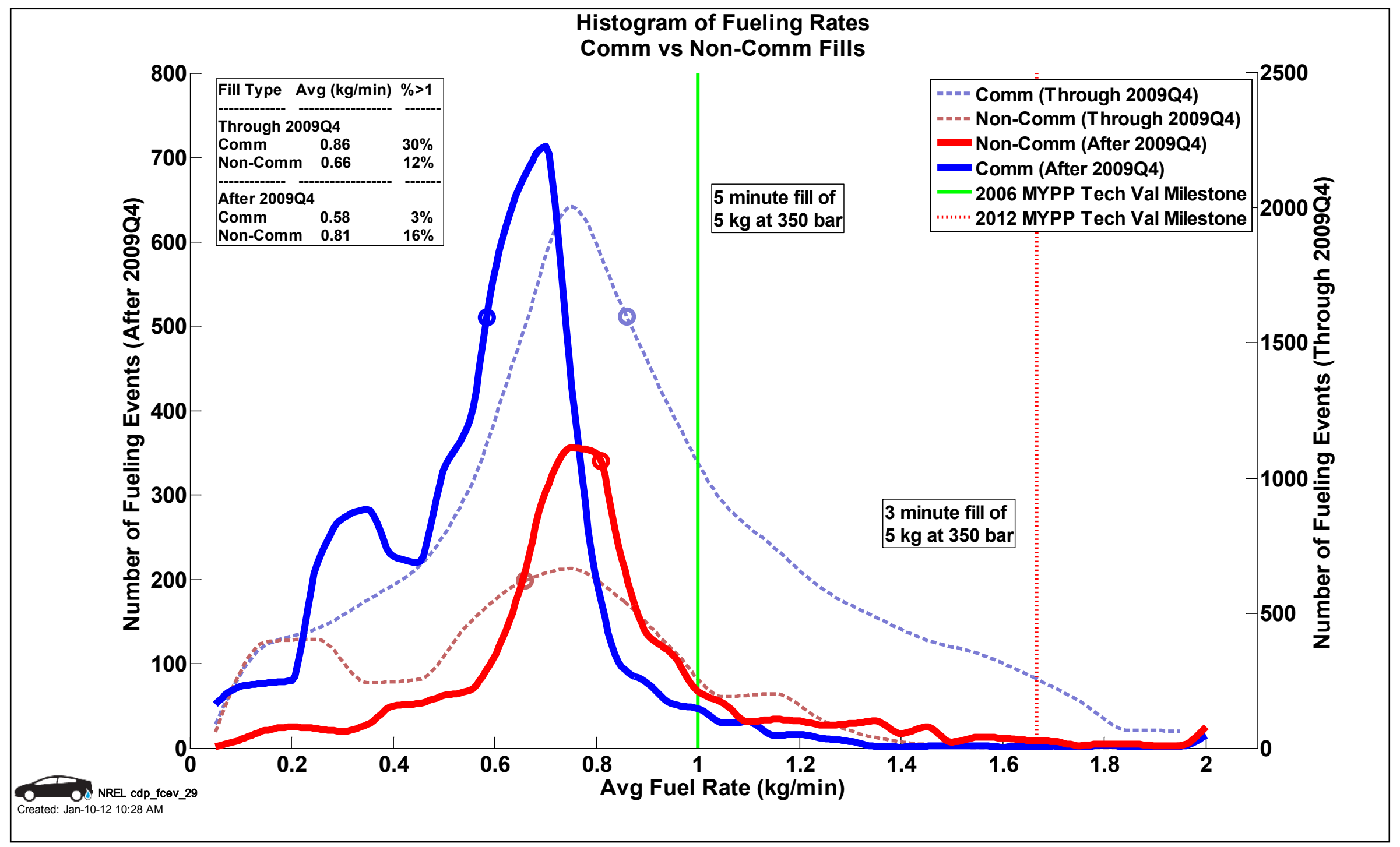




\section{CDP\#30: Infrastructure Maintenance}

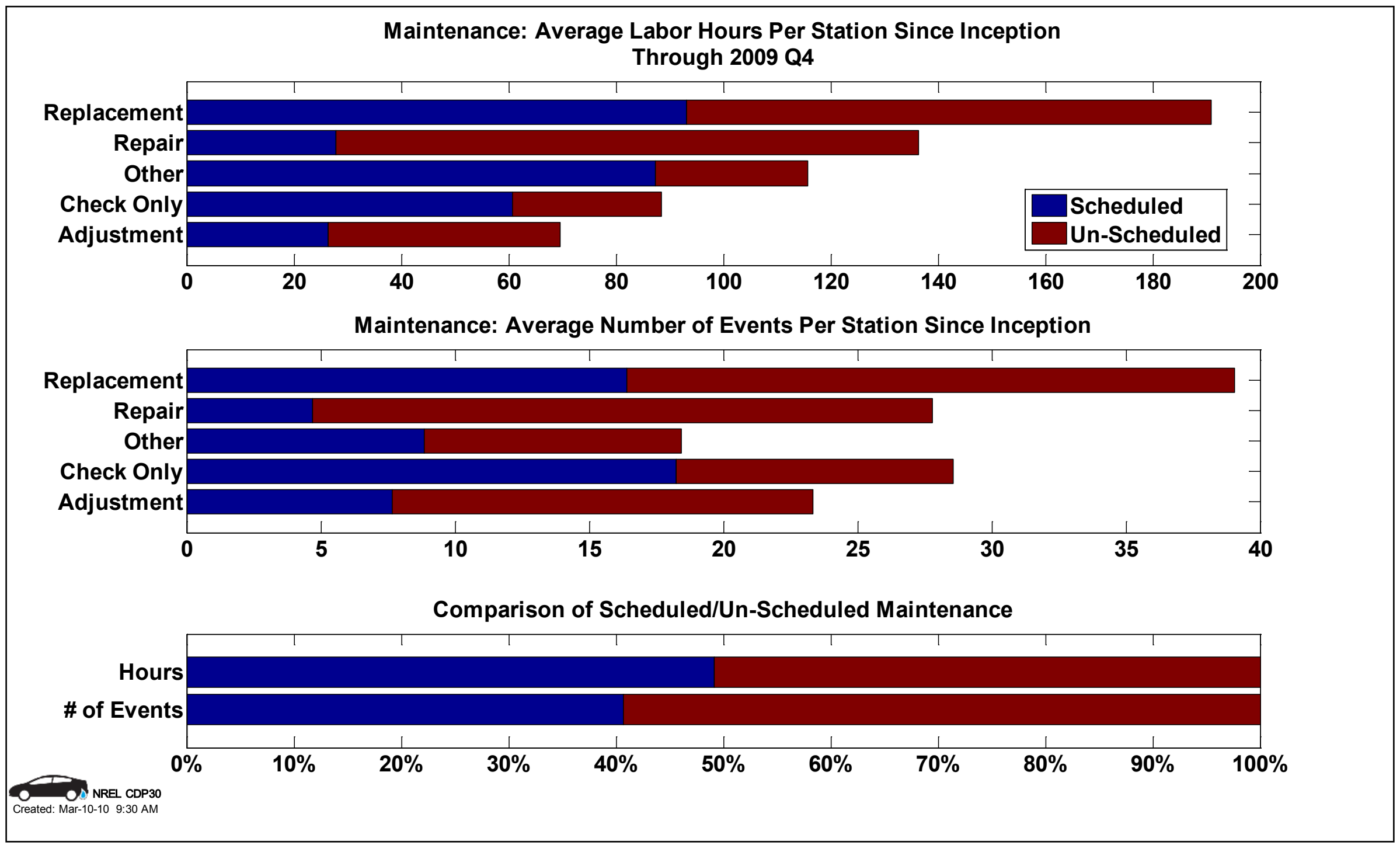




\section{CDP\#31: Number of Online Stations}

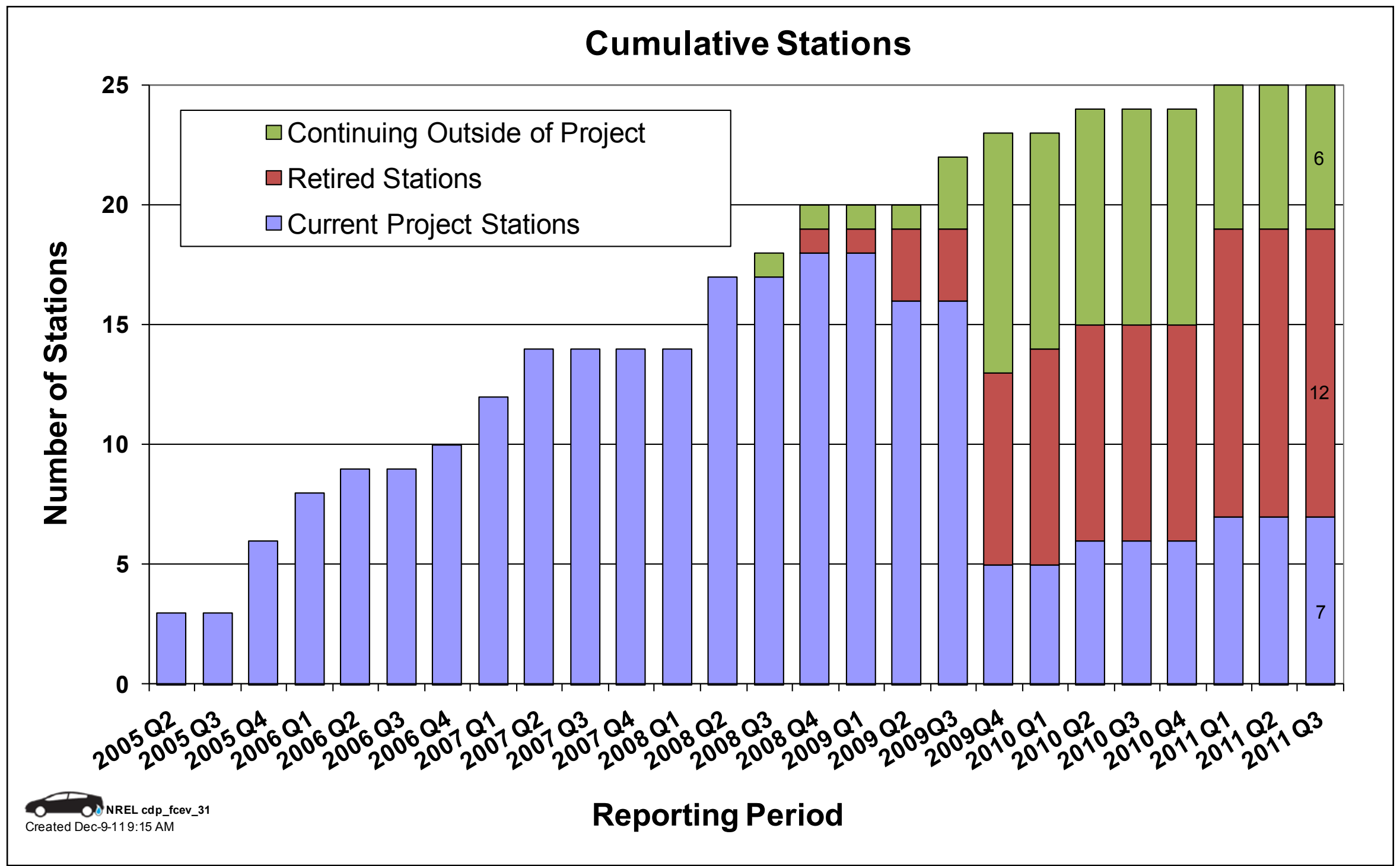




\section{CDP\#32: Infrastructure Hydrogen Production Methods}

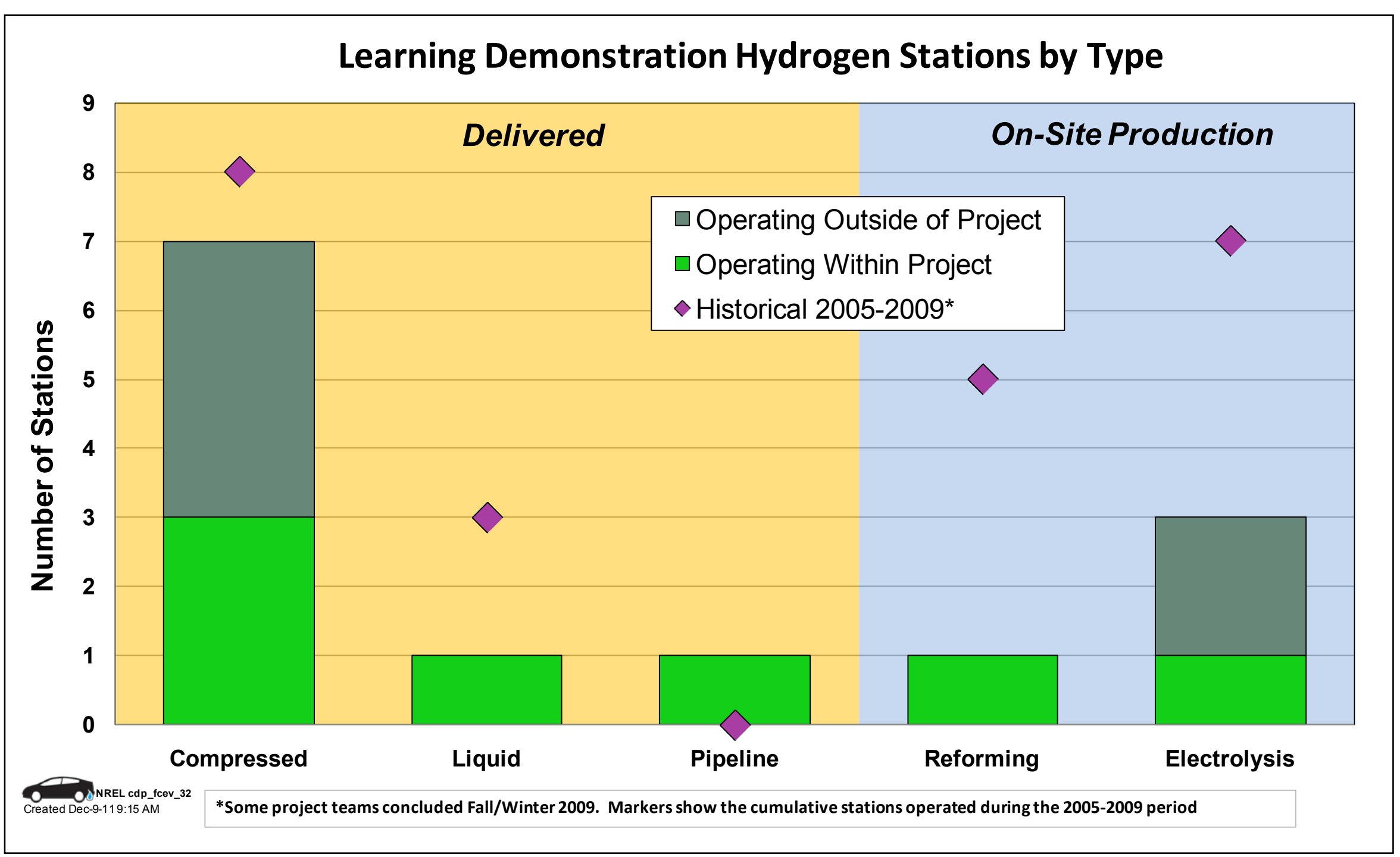




\section{CDP\#33: Percentage of Theoretical Range Traveled Between Refuelings}

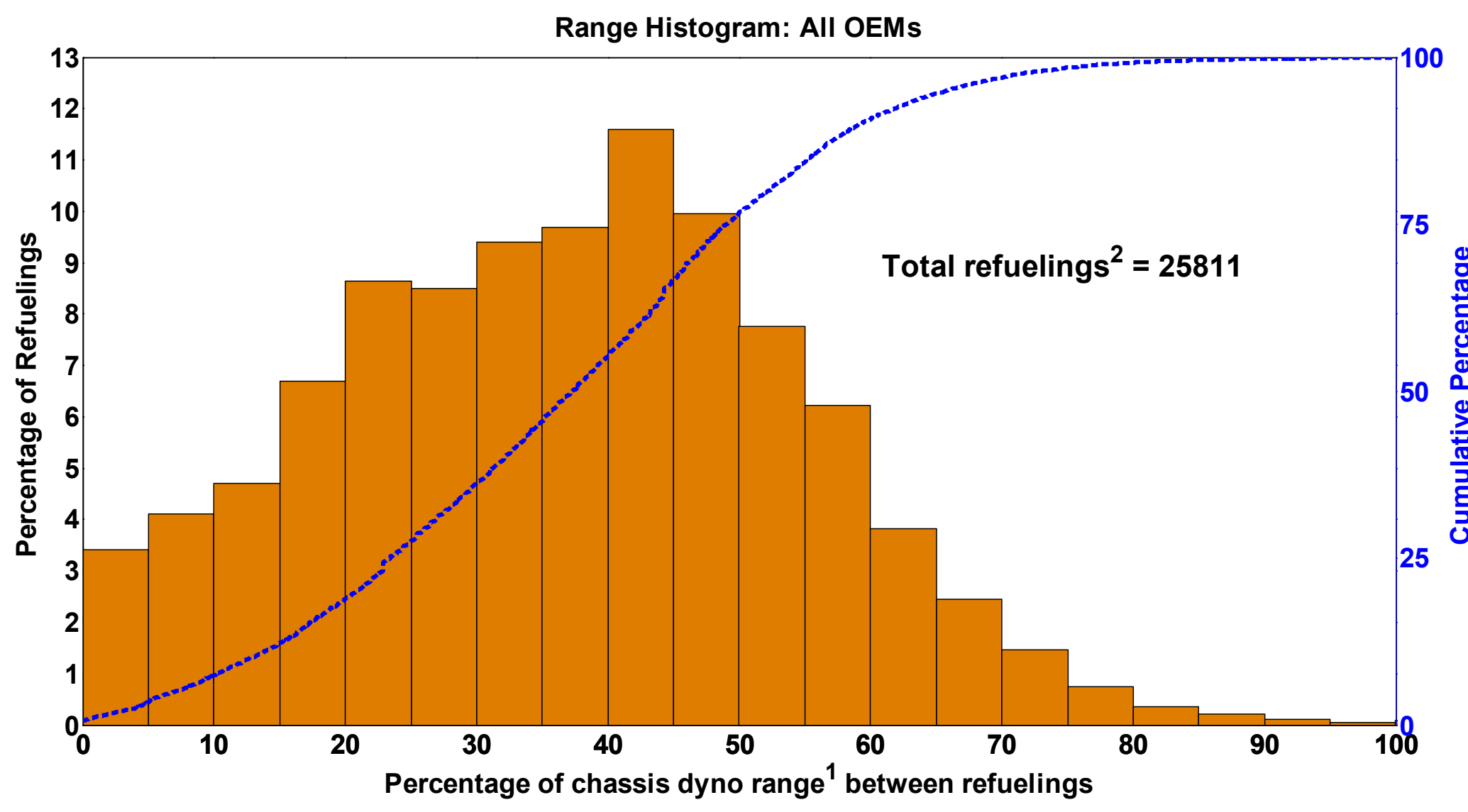

1. Range calculated using the combined City/Hwy fuel economy from dyno testing (not EPA adjusted) and usable fuel on board.

2. Some refueling events are not detected/reported due to data noise or incompleteness. 


\section{CDP\#34: Effective Vehicle Range}

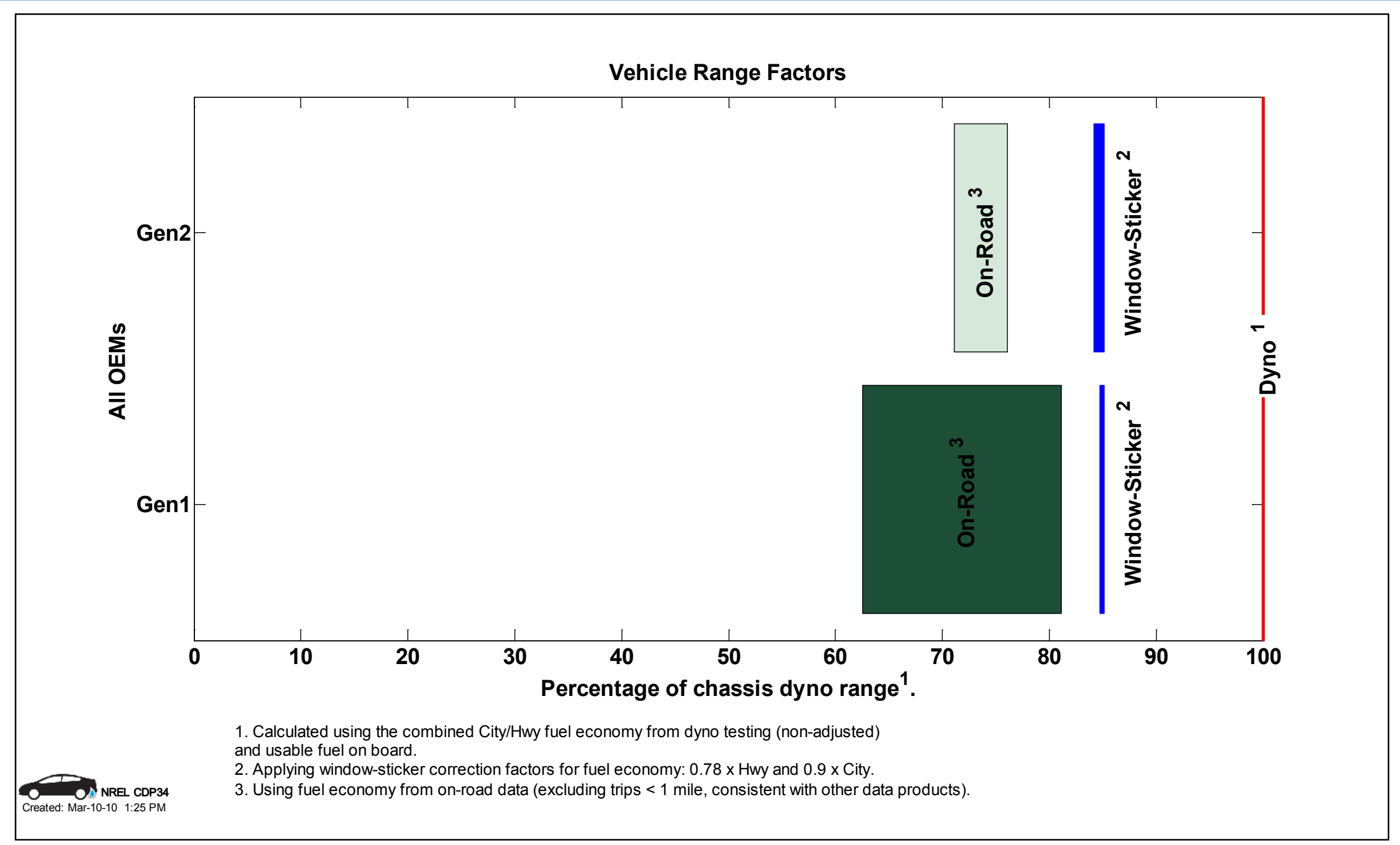




\section{CDP\#35: Average Refuelings Between Infrastructure Safety Reports}

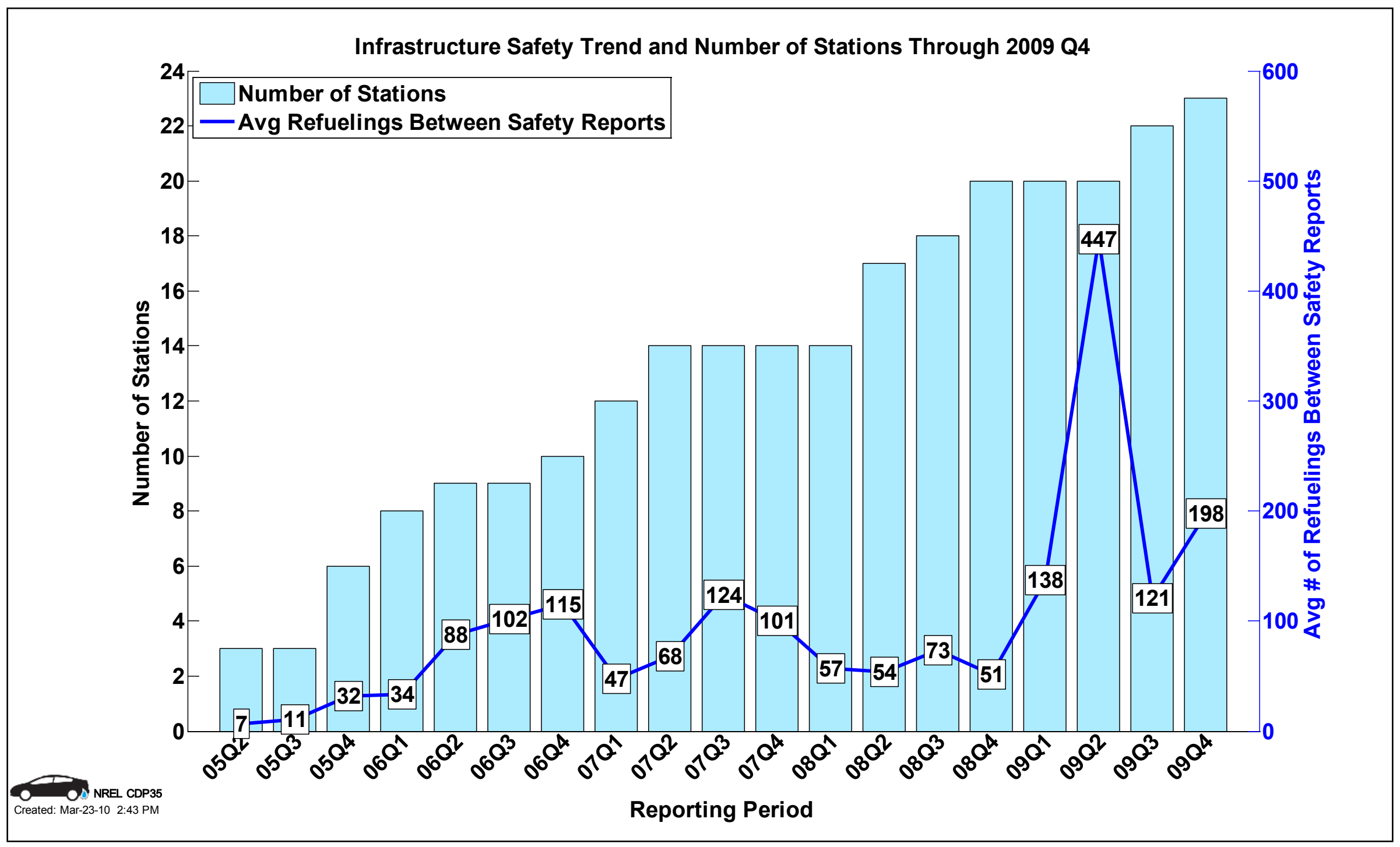




\section{CDP\#36: Type of Infrastructure Safety Report By Quarter}

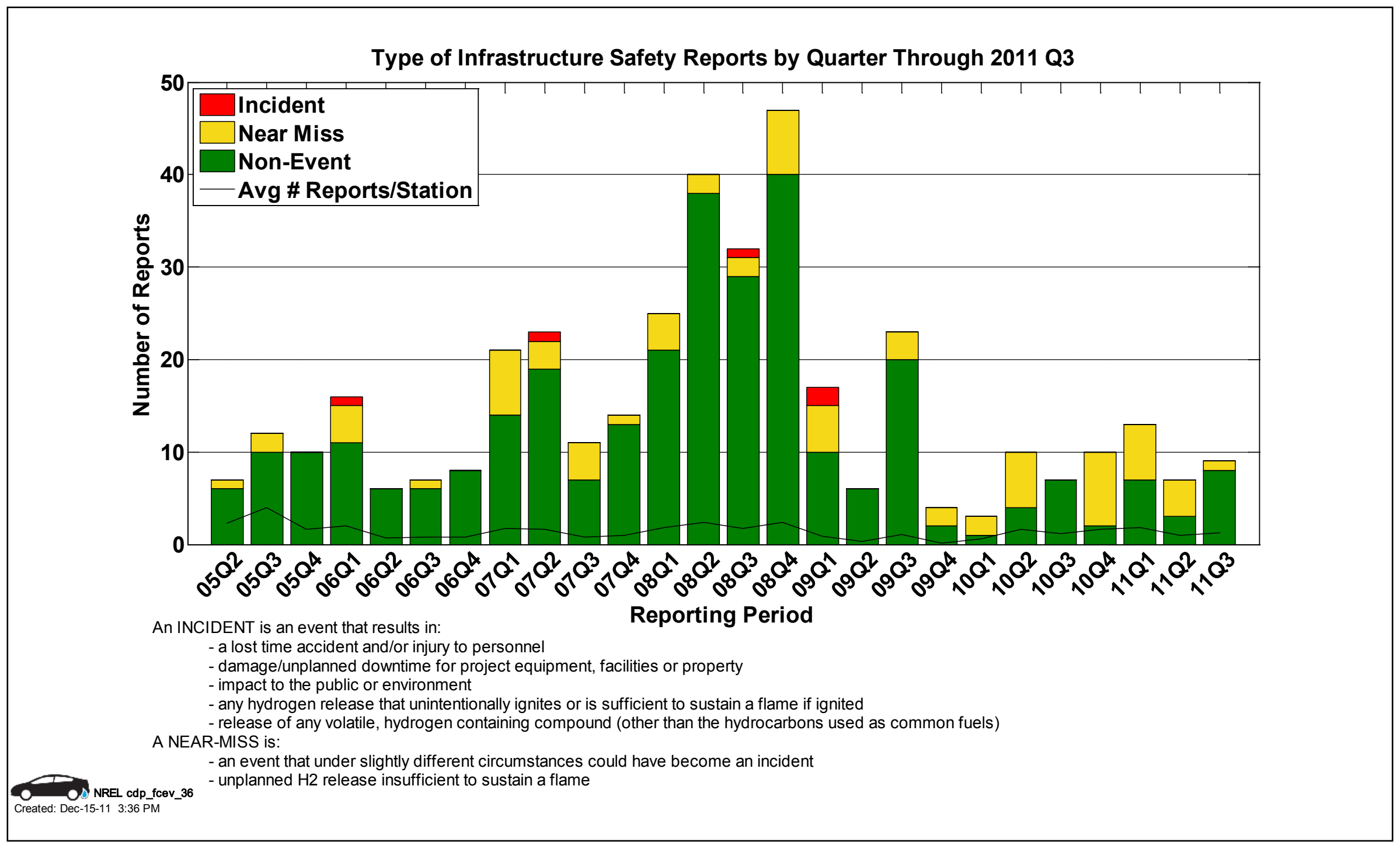




\section{CDP\#37: Primary Factors of Infrastructure Safety Reports}

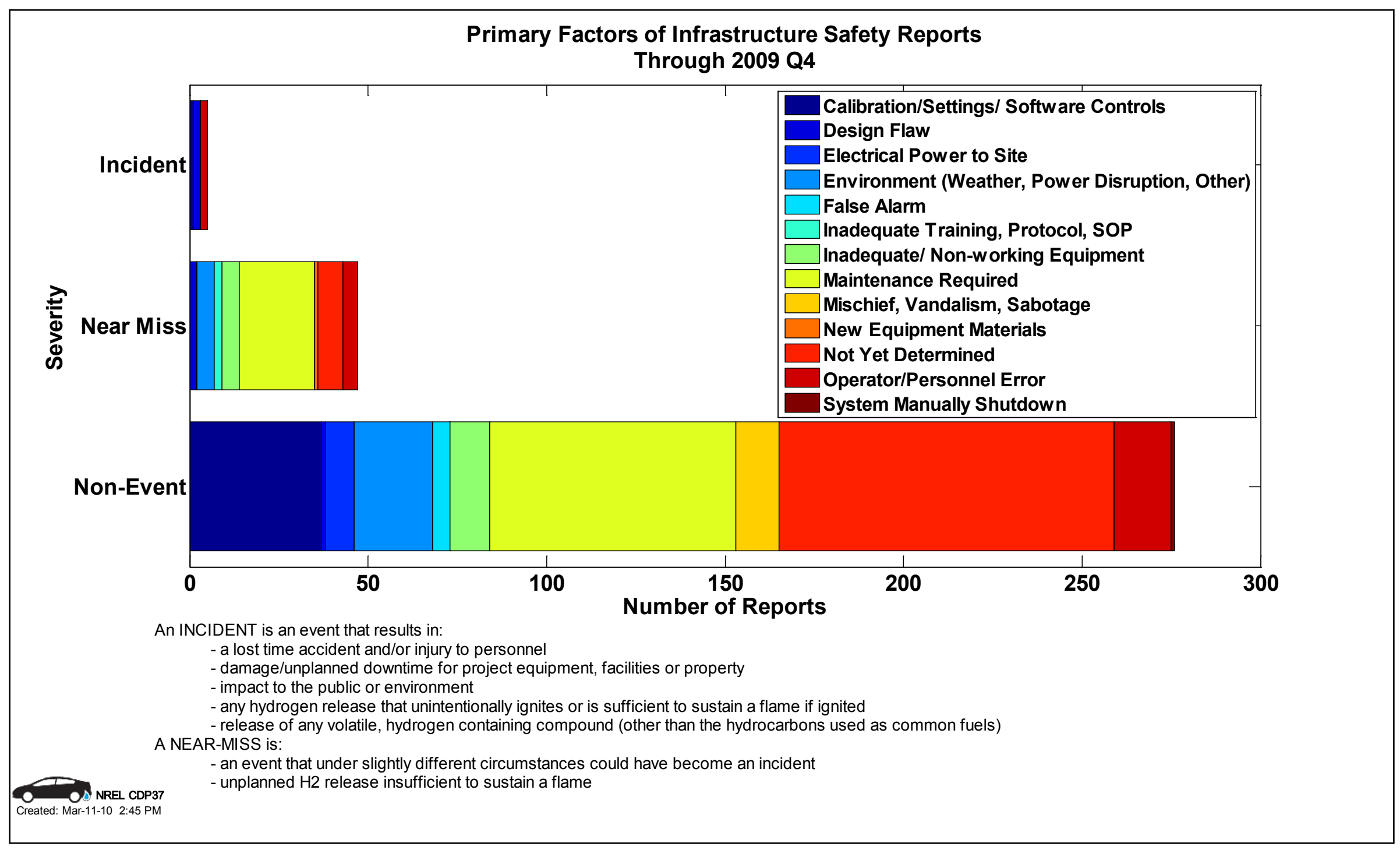




\section{CDP\#38: Refueling Times}

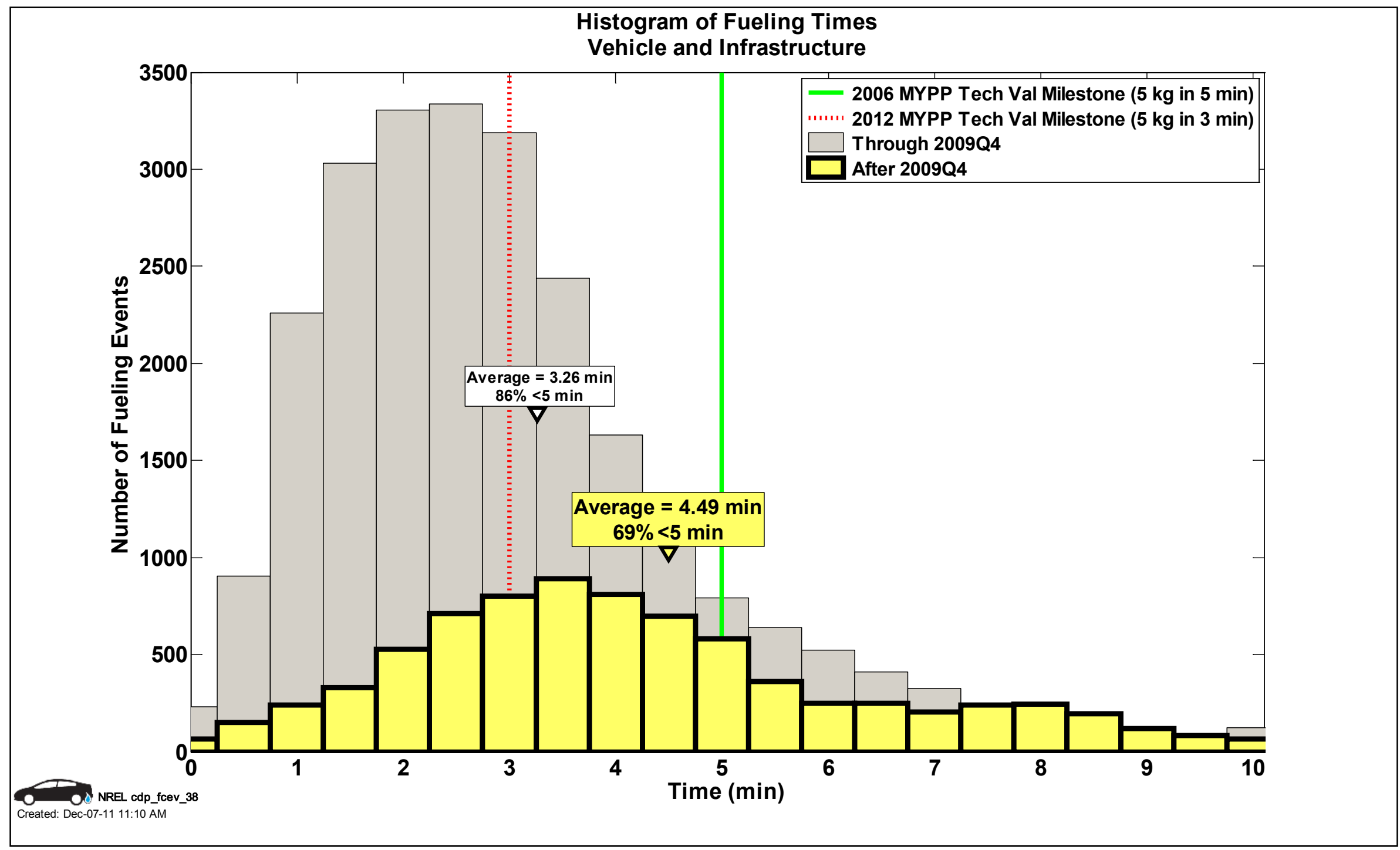




\section{CDP\#39: Refueling Amounts}

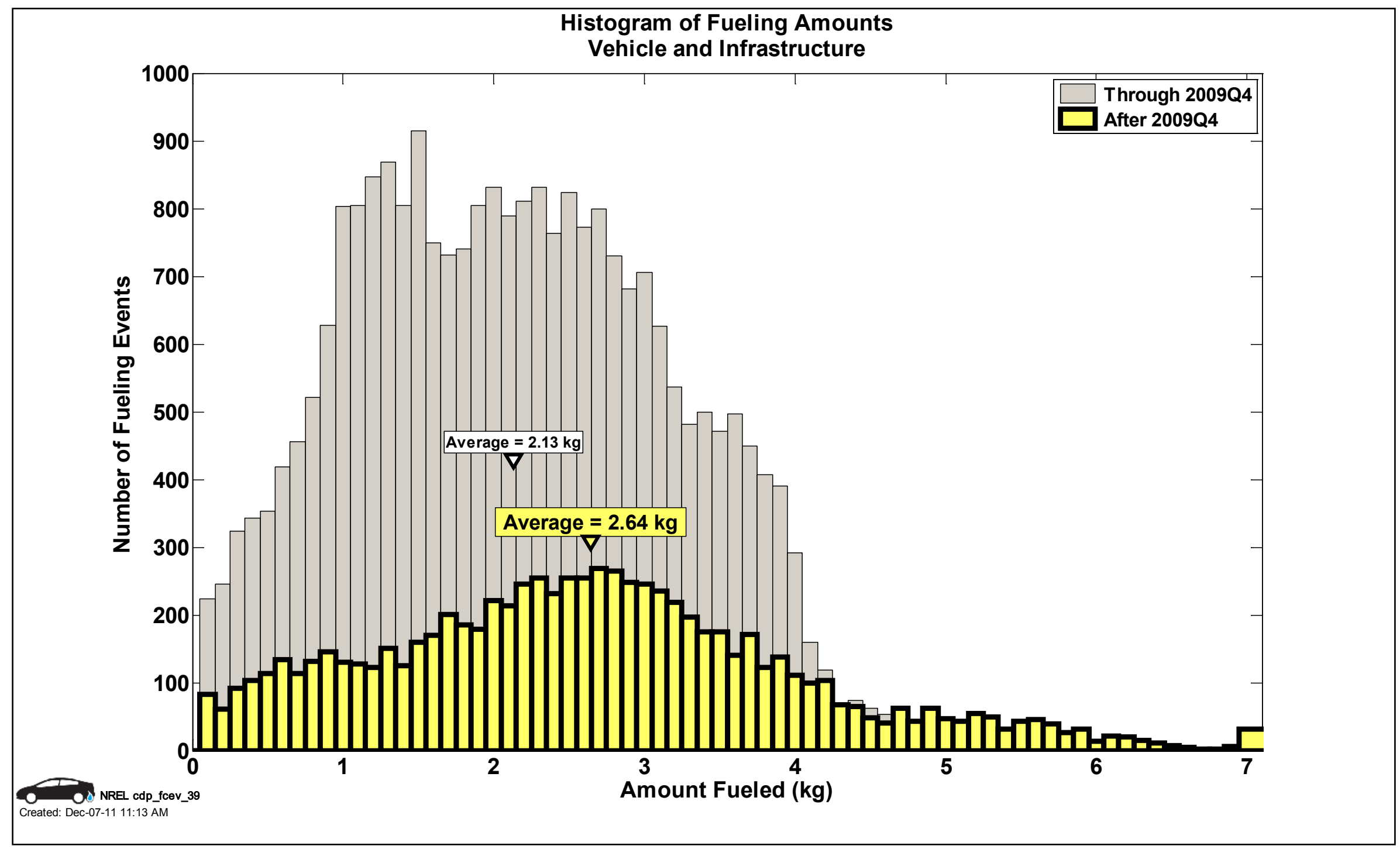




\section{CDP\#40: H2 Tank Level at Refueling}

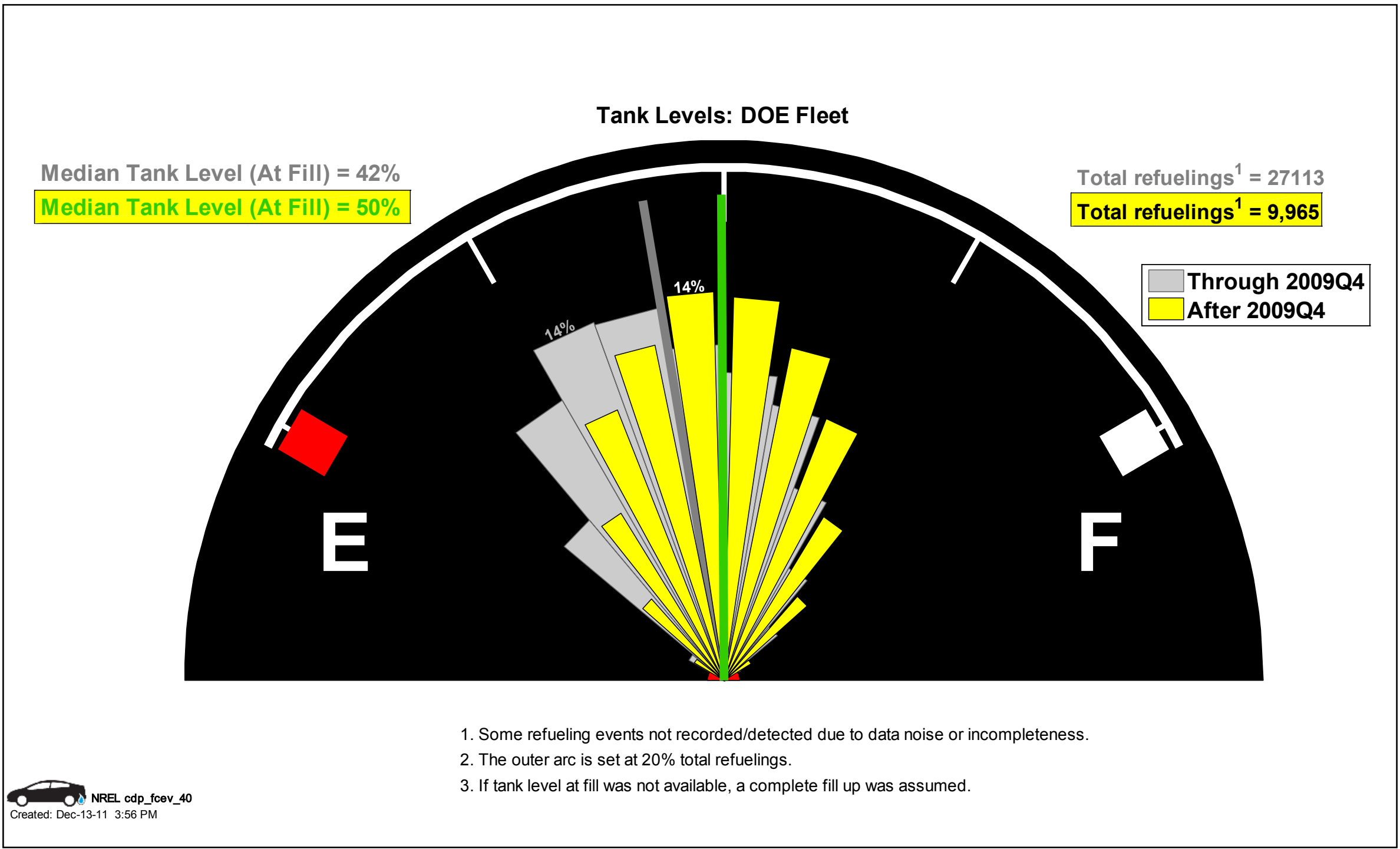




\section{CDP\#41: Refueling Tank Levels - Medians}

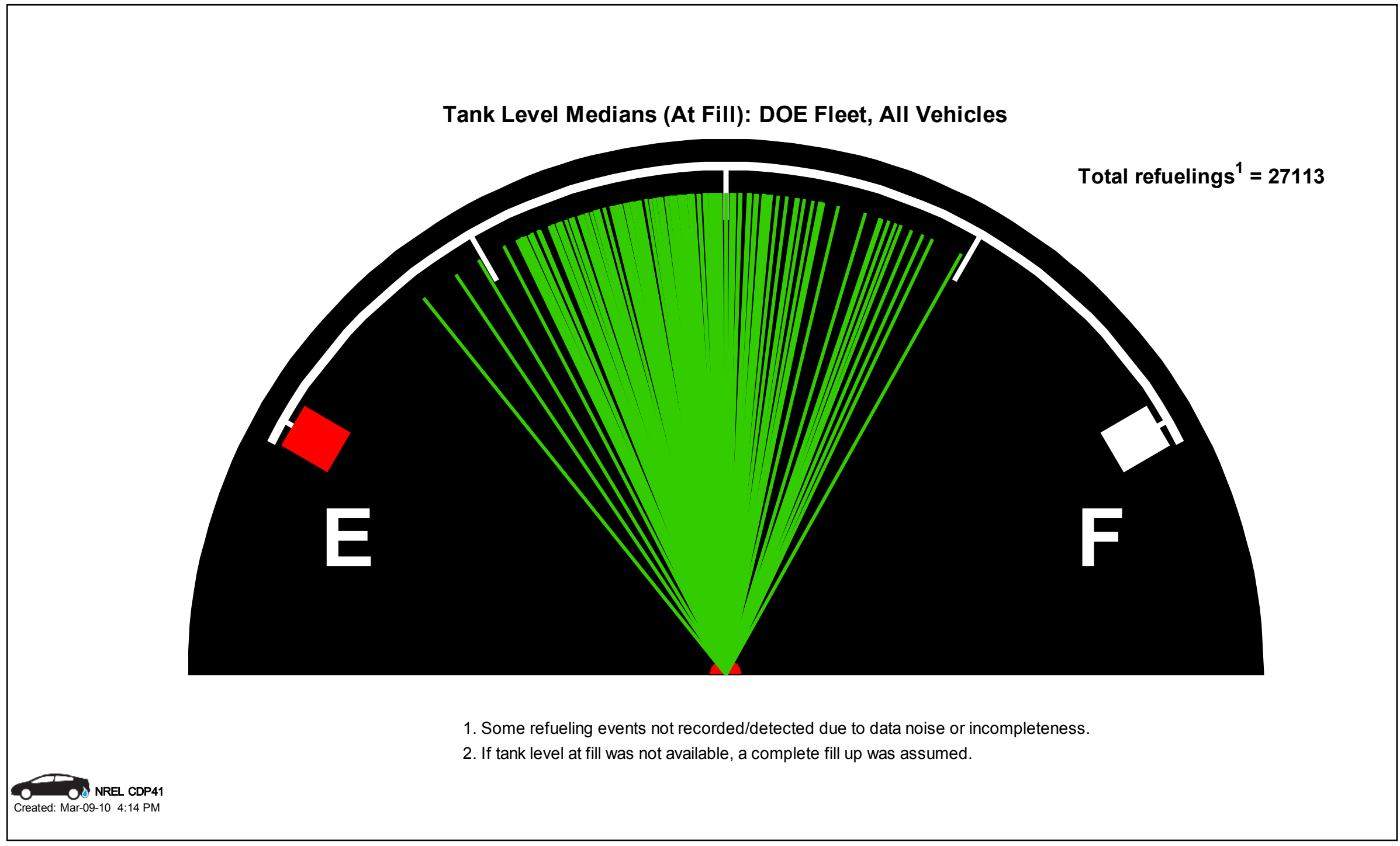




\section{CDP\#42: Refueling by Time of Day}

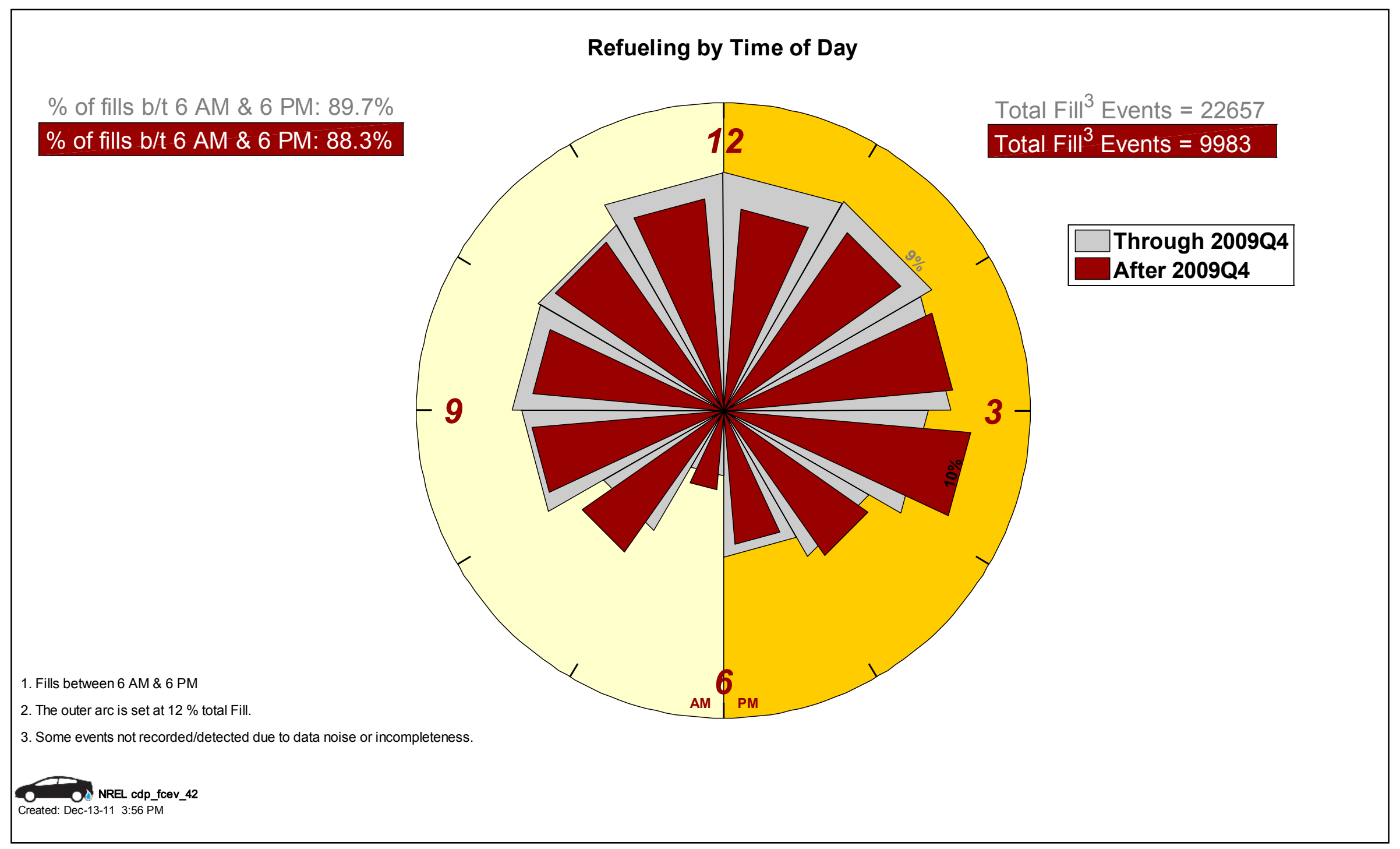




\section{CDP\#43: Refueling by Day of Week}

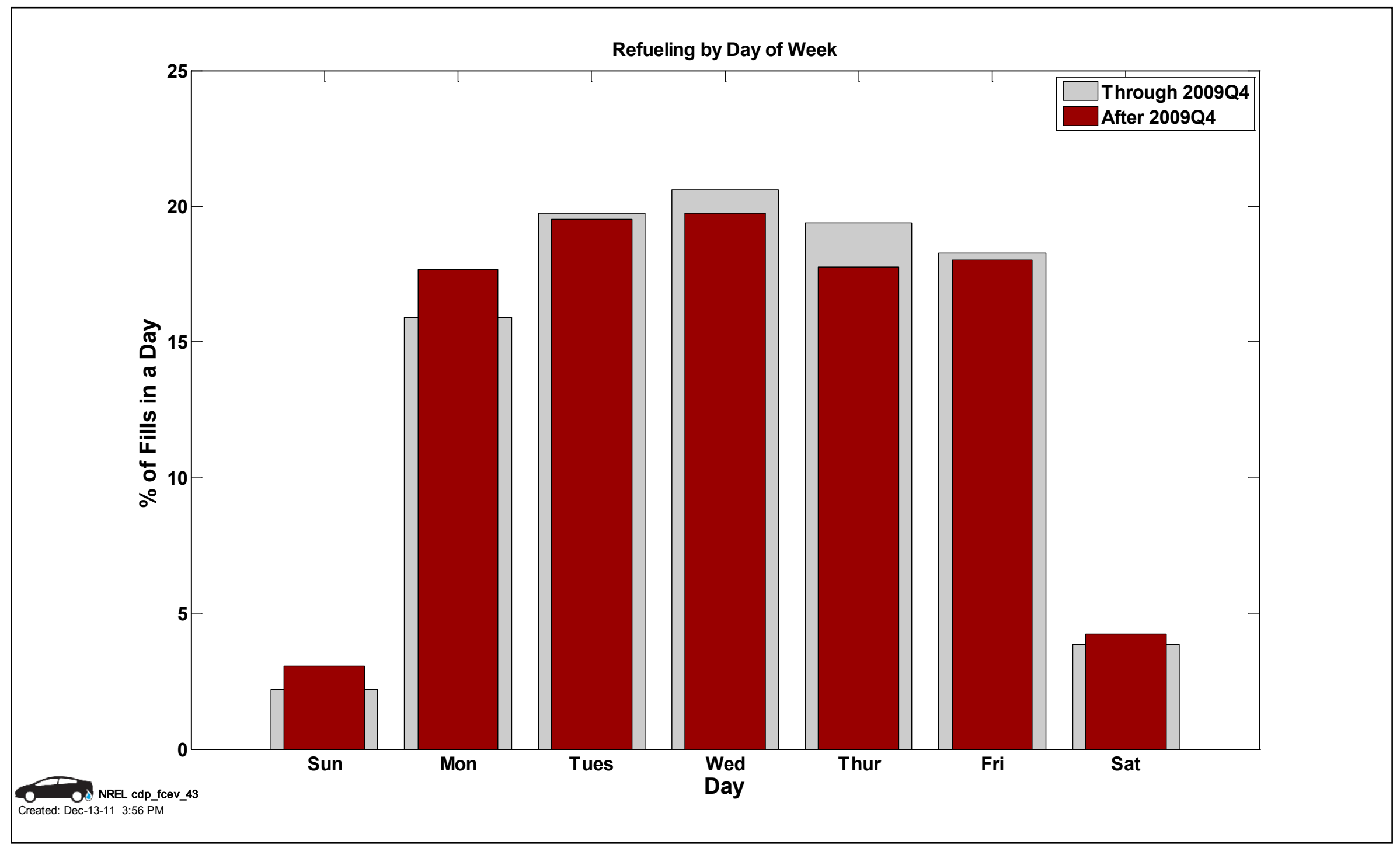




\section{CDP\#44: Driving Start Time - Day}

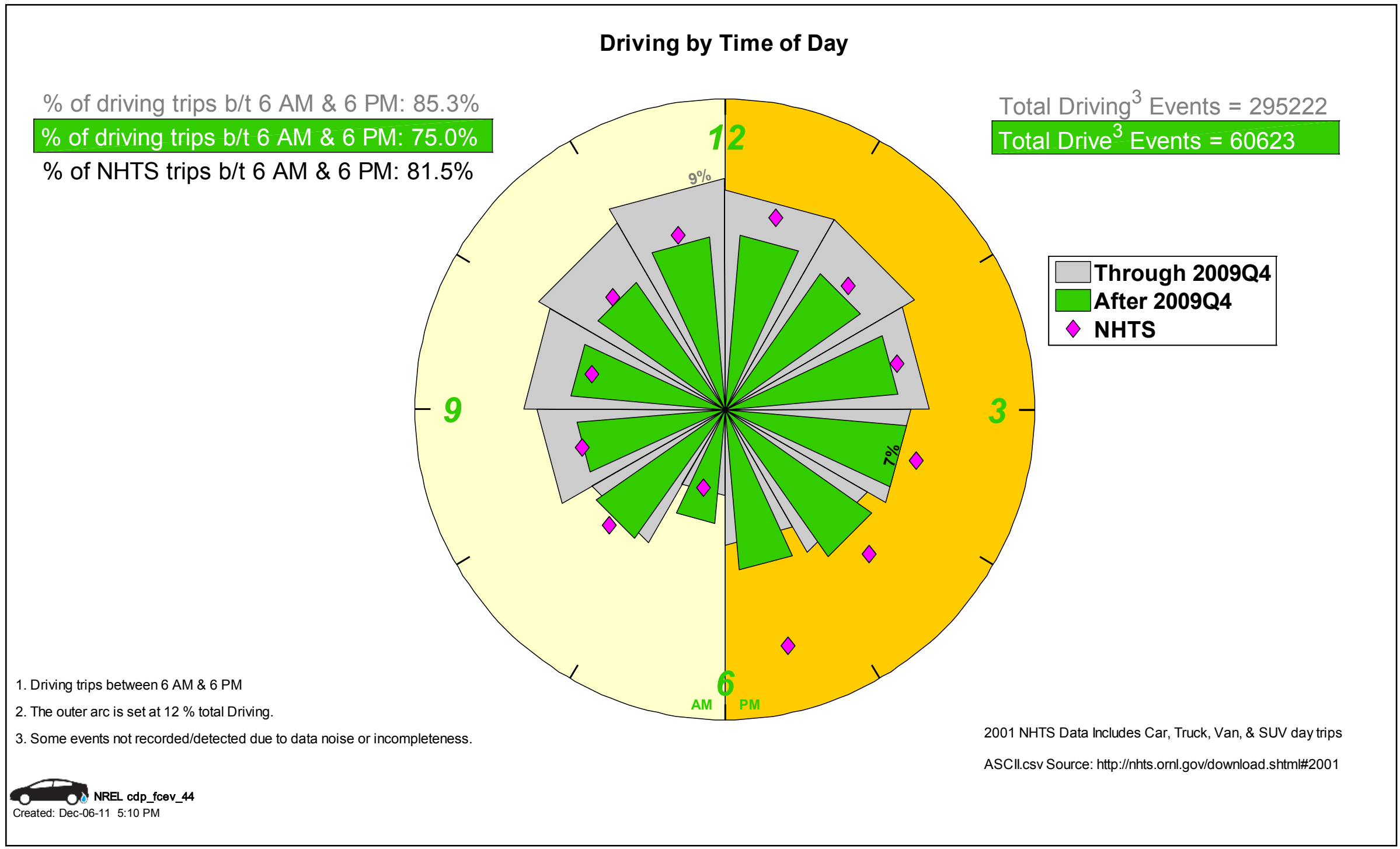




\section{CDP\#45: Driving by Day of Week}

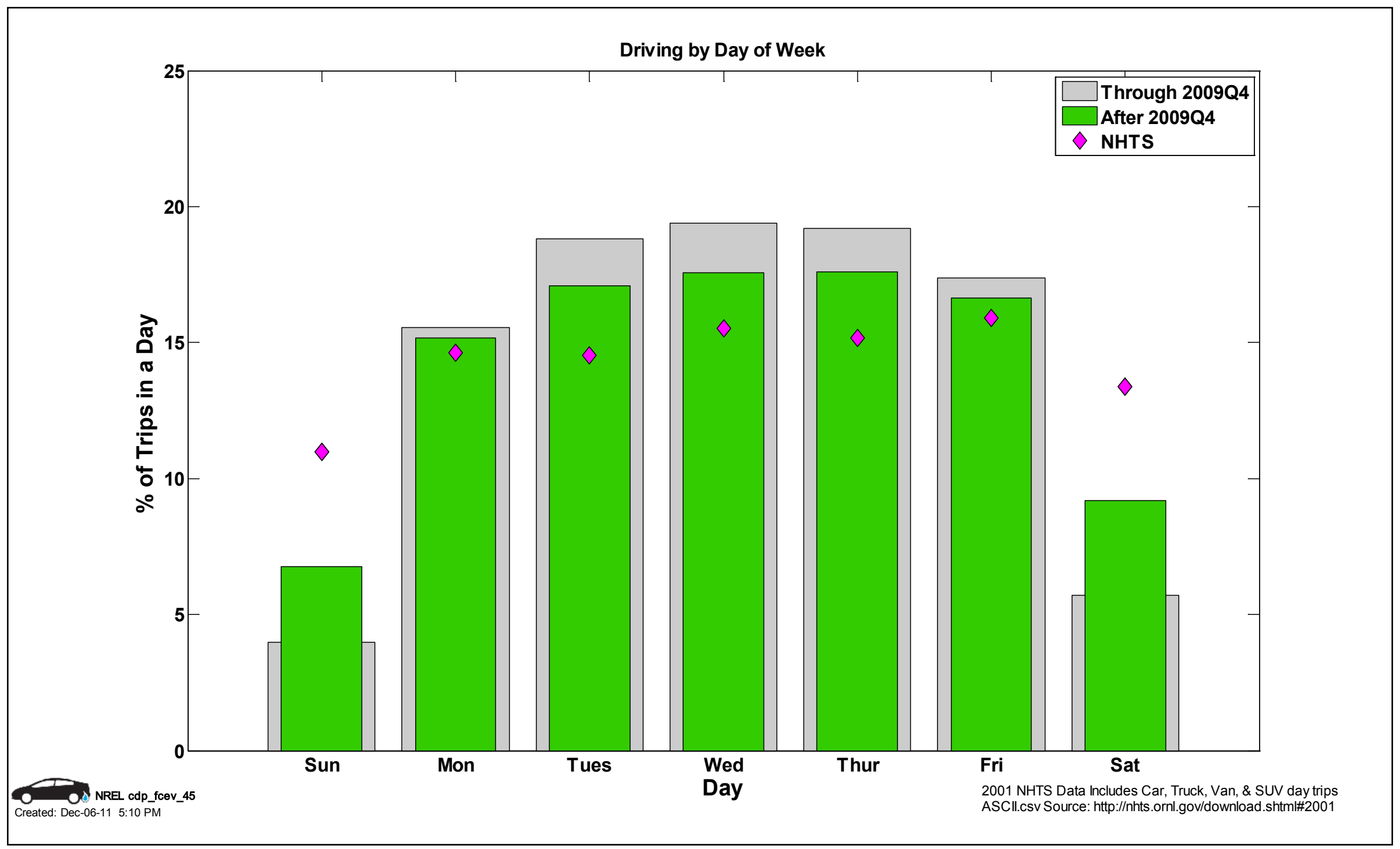




\section{CDP\#46: Fuel Cell System Operating Power}

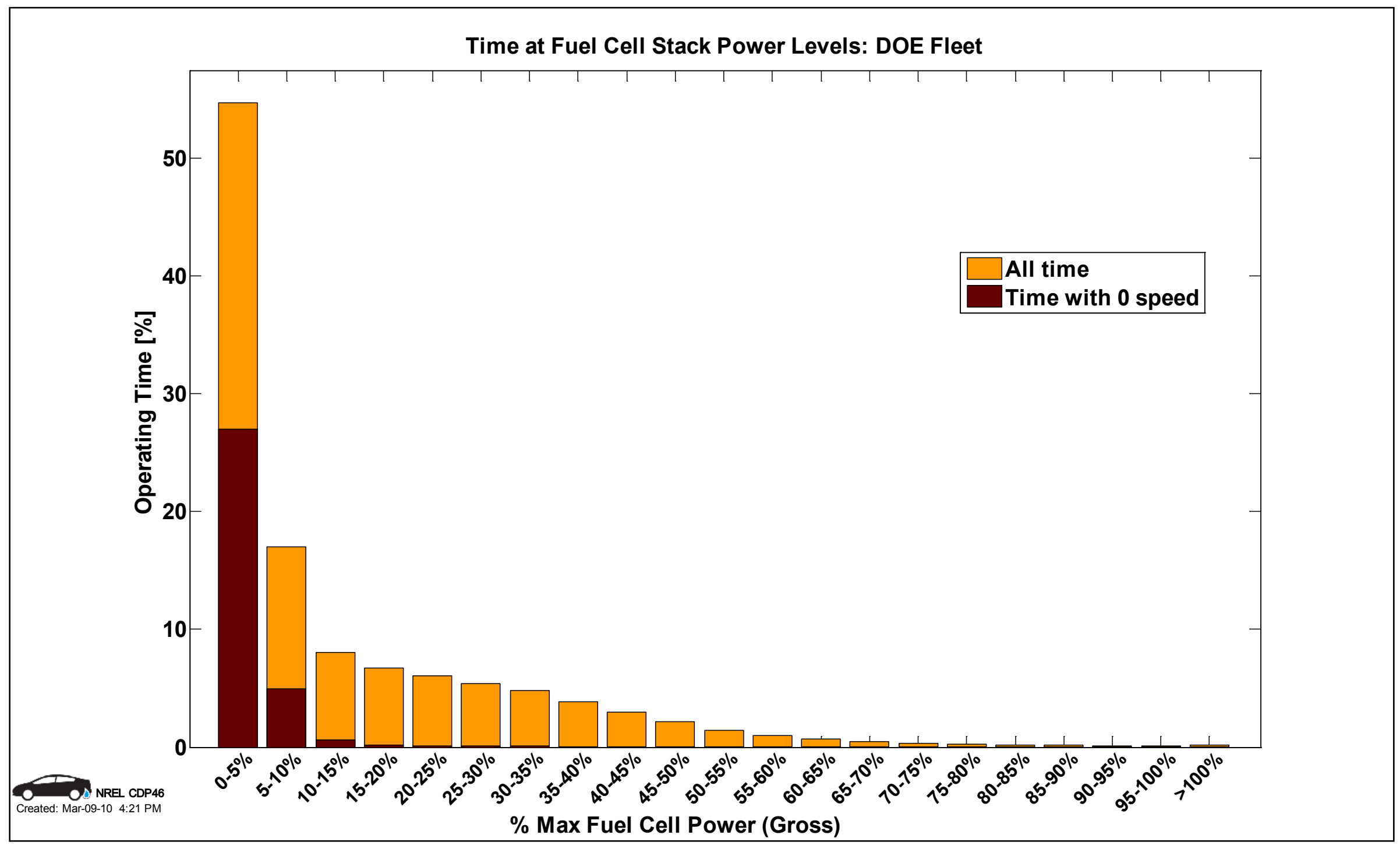




\section{CDP\#47: Trip Length}

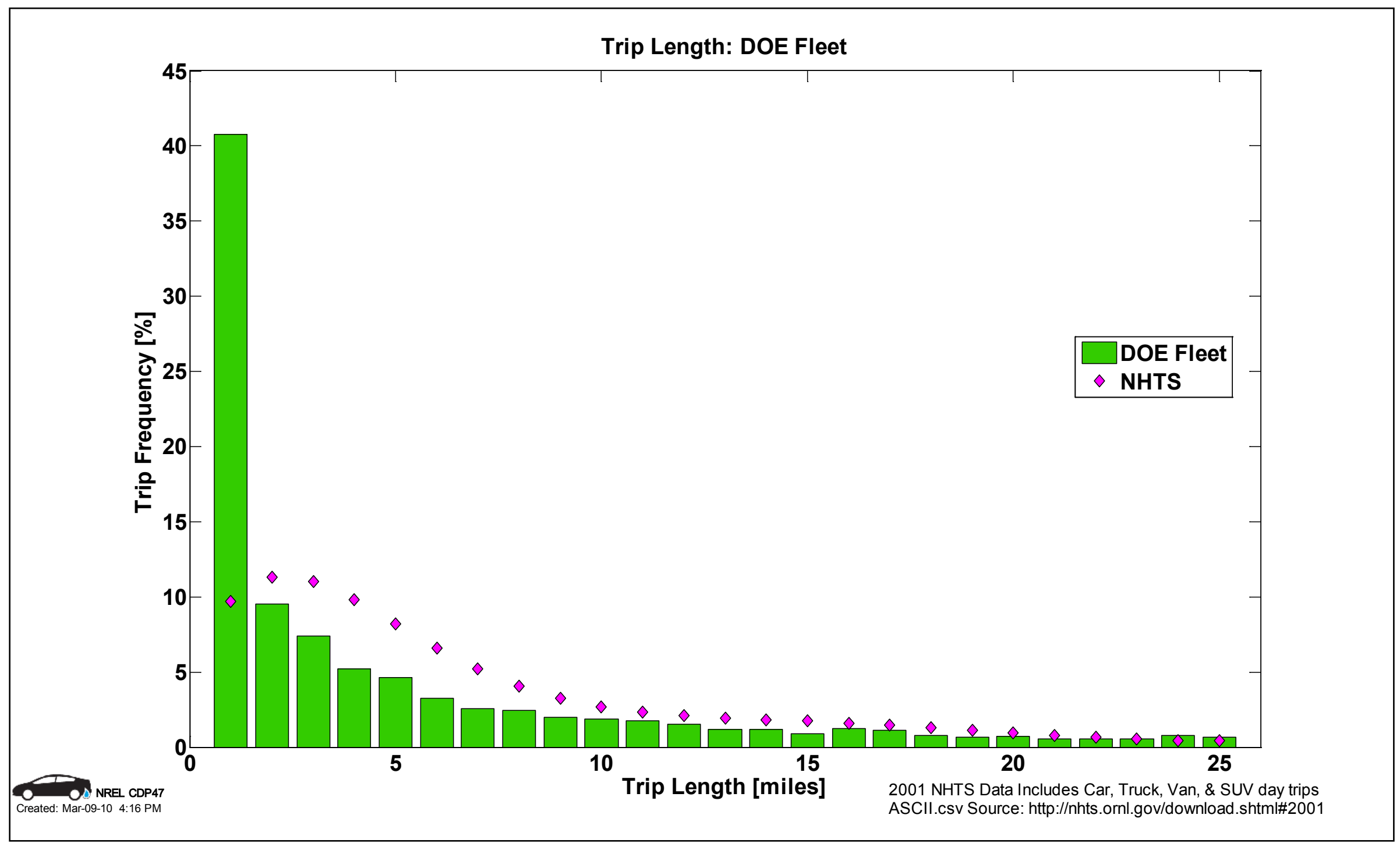




\section{CDP\#48: Primary Factors Affecting Learning Demo Fleet Fuel Cell Degradation}

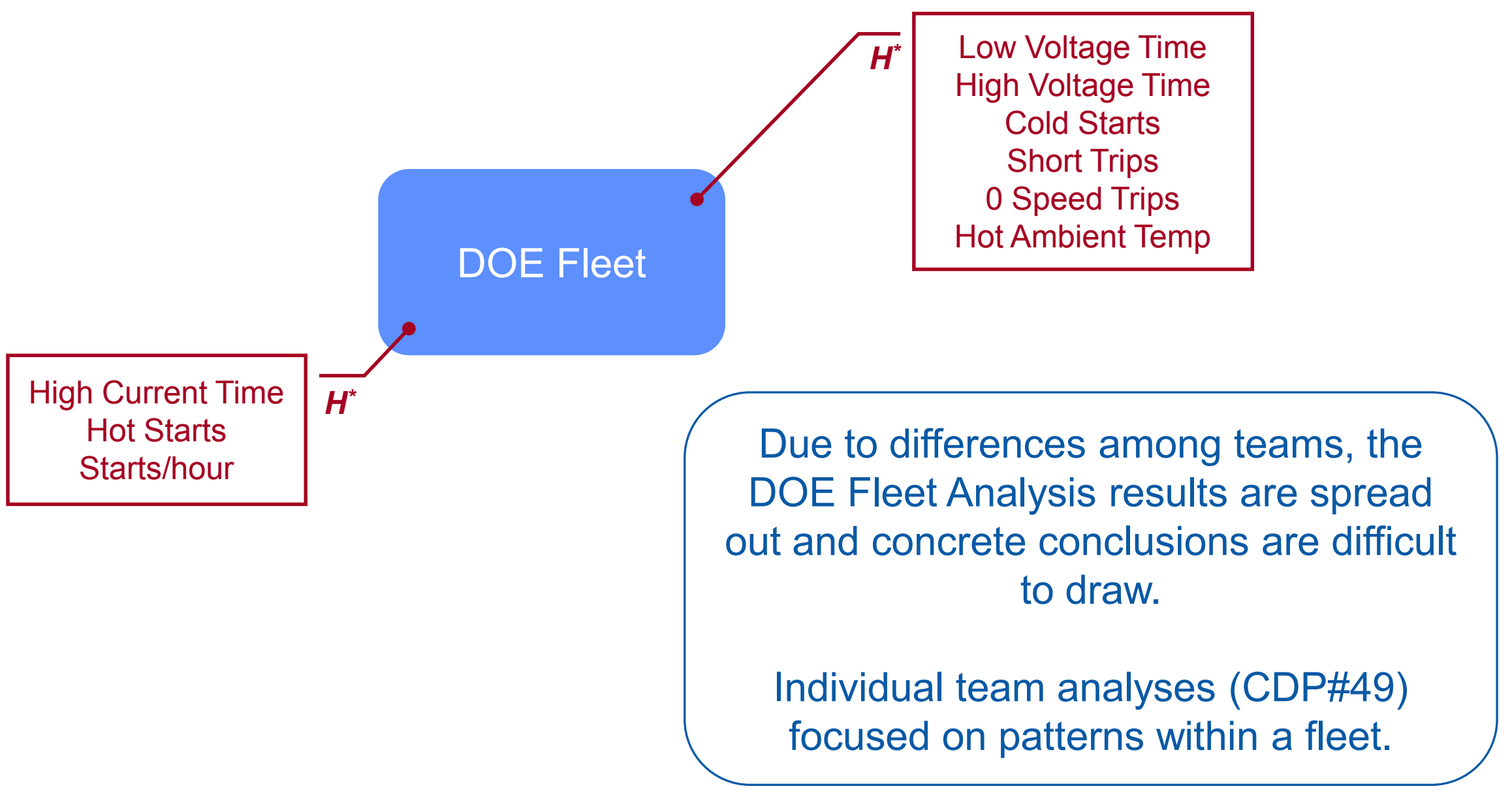

1) On-going fuel cell degradation study using Partial Least Squares (PLS) regression model for combined Learning Demonstration Fleet.

2) DOE Fleet model has a low percentage of explained decay rate variance.
$\mathrm{H}^{*}$ : Factor group associated with high decay rate fuel cell stacks $L^{* *}$ : Factor group associated with low decay rate fuel cell stacks 


\section{CDP\#49: Primary Factors Affecting Learning Demo Team Fuel Cell Degradation}
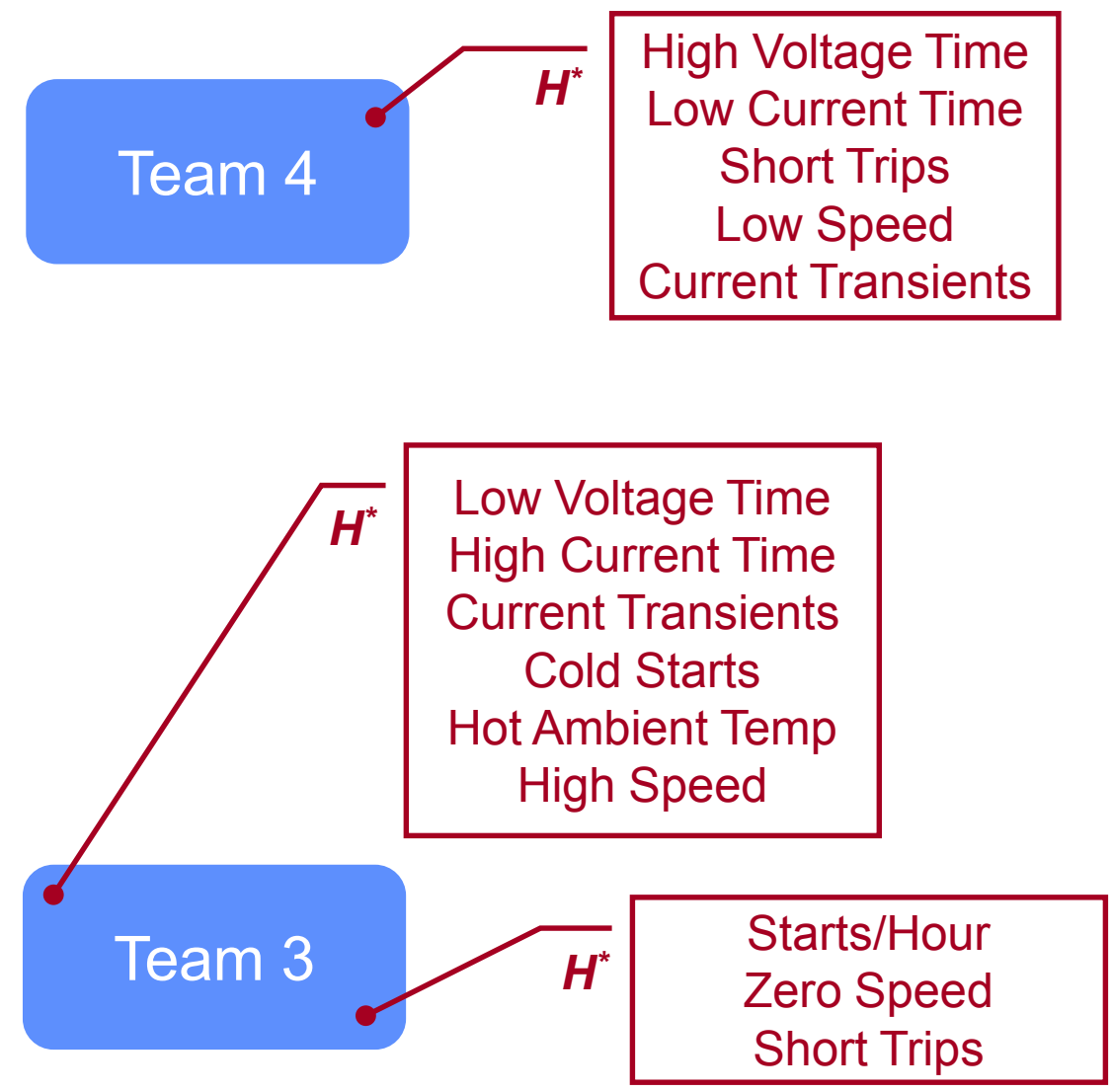

1) On-going fuel cell degradation study using Partial Least Squares (PLS) regression model for each team's Gen 1 fleet.

2) Teams' PLS models have a high percentage of explained decay rate variance, but the models are not robust and results are scattered.

3) Factor groups associated with stacks that are opposite to the identified groups here are not specified.

\begin{tabular}{|c|}
\hline Low Current Time \\
Long Trips \\
Warm Ambient Temp \\
Zero Speed \\
Current Transients
\end{tabular}
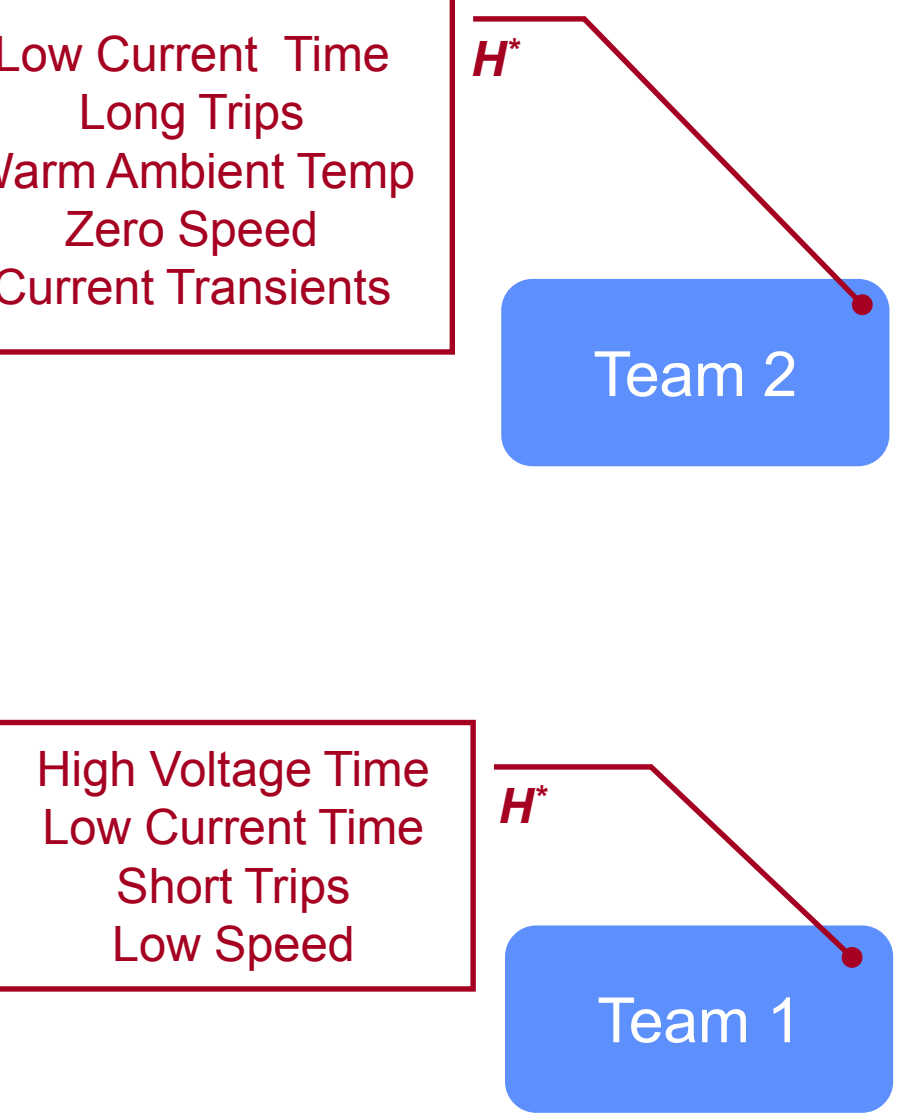

$\mathrm{H}^{*}$ : Factor group associated with high decay rate fuel cell stacks 


\section{CDP\#50: Refueling by Time of Night}

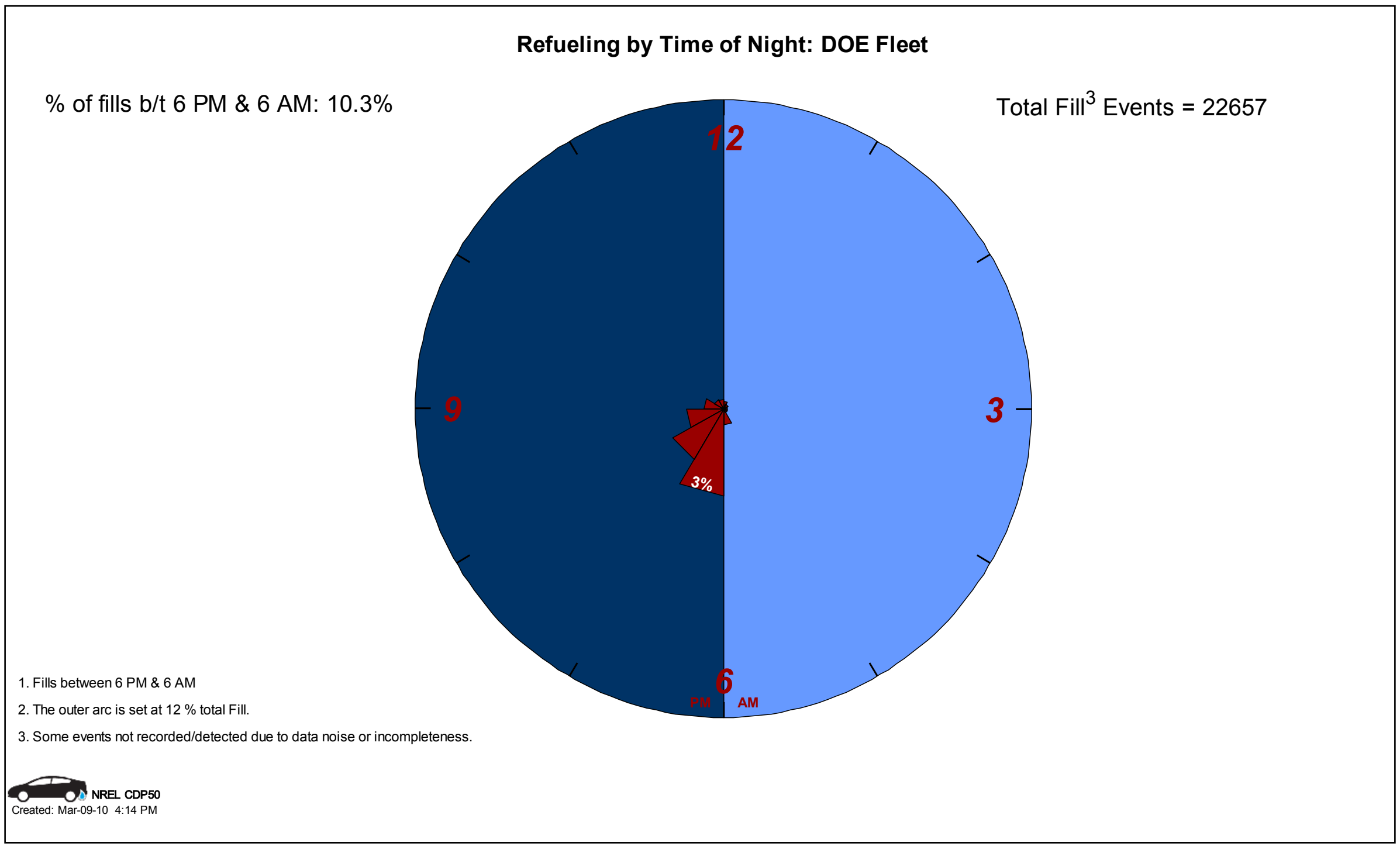




\section{CDP\#51: Driving Start Time - Night}

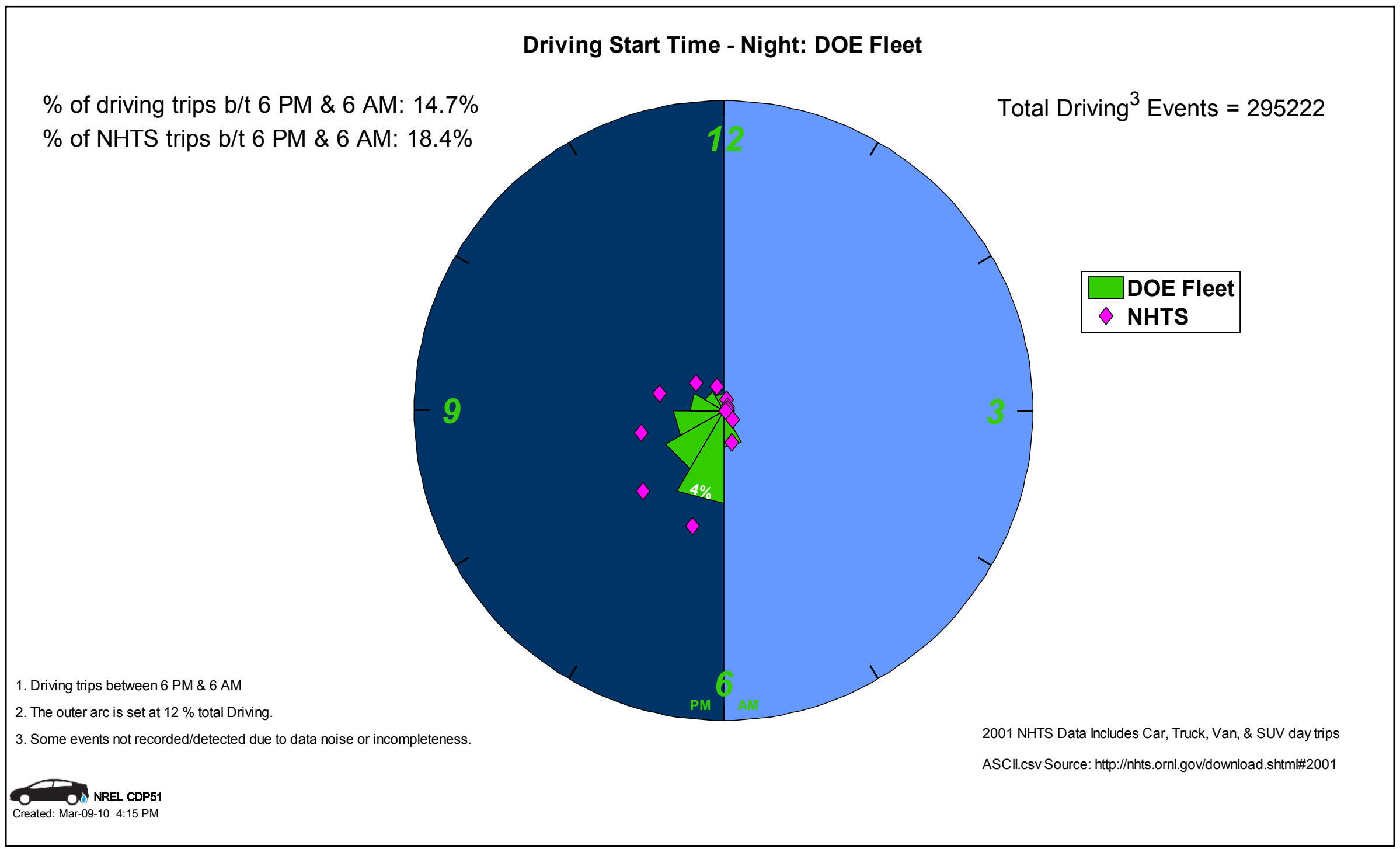




\section{CDP\#52: Fueling Rates by Year}

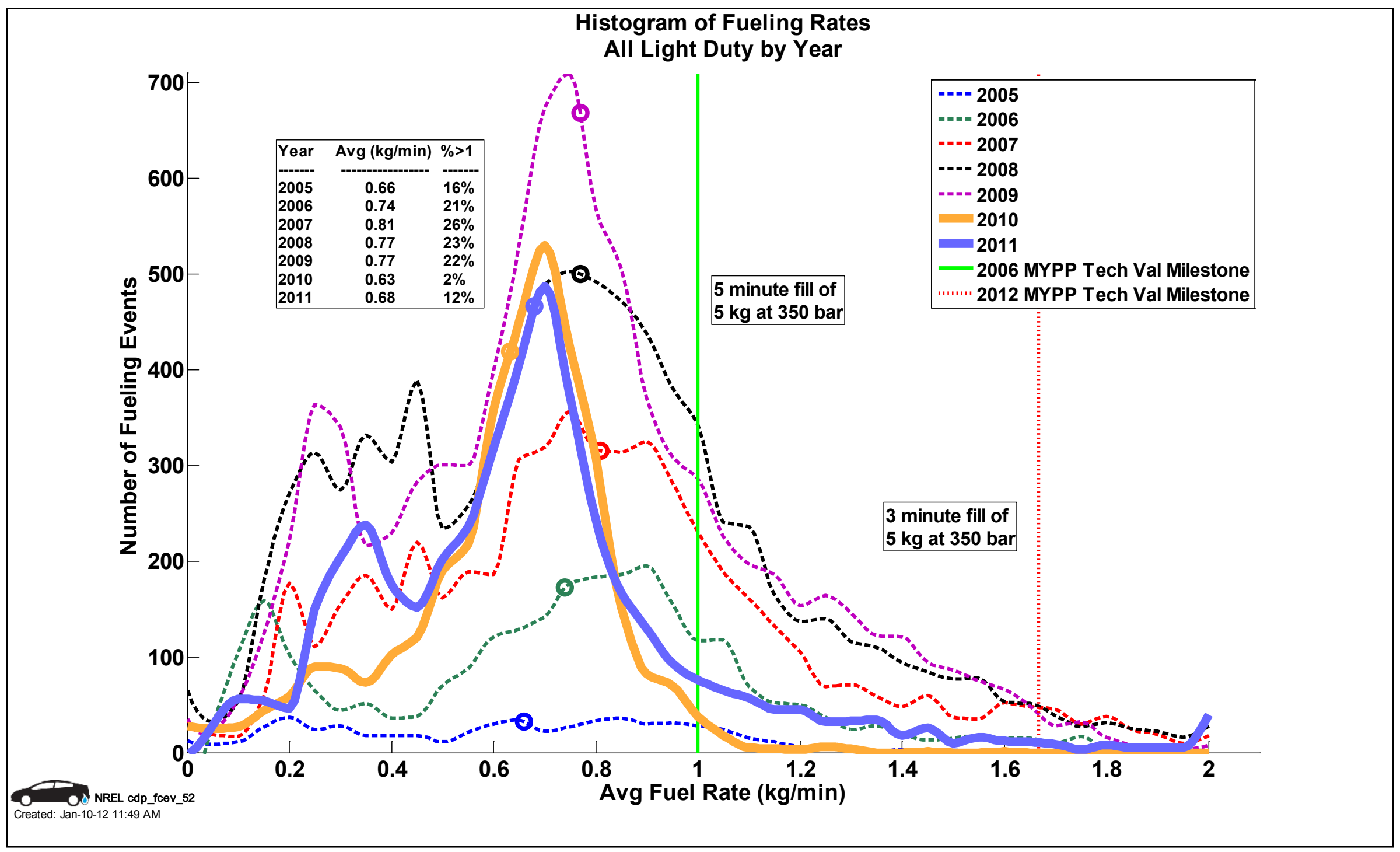




\section{CDP\#53: Fuel Cell System Energy within Power Levels}

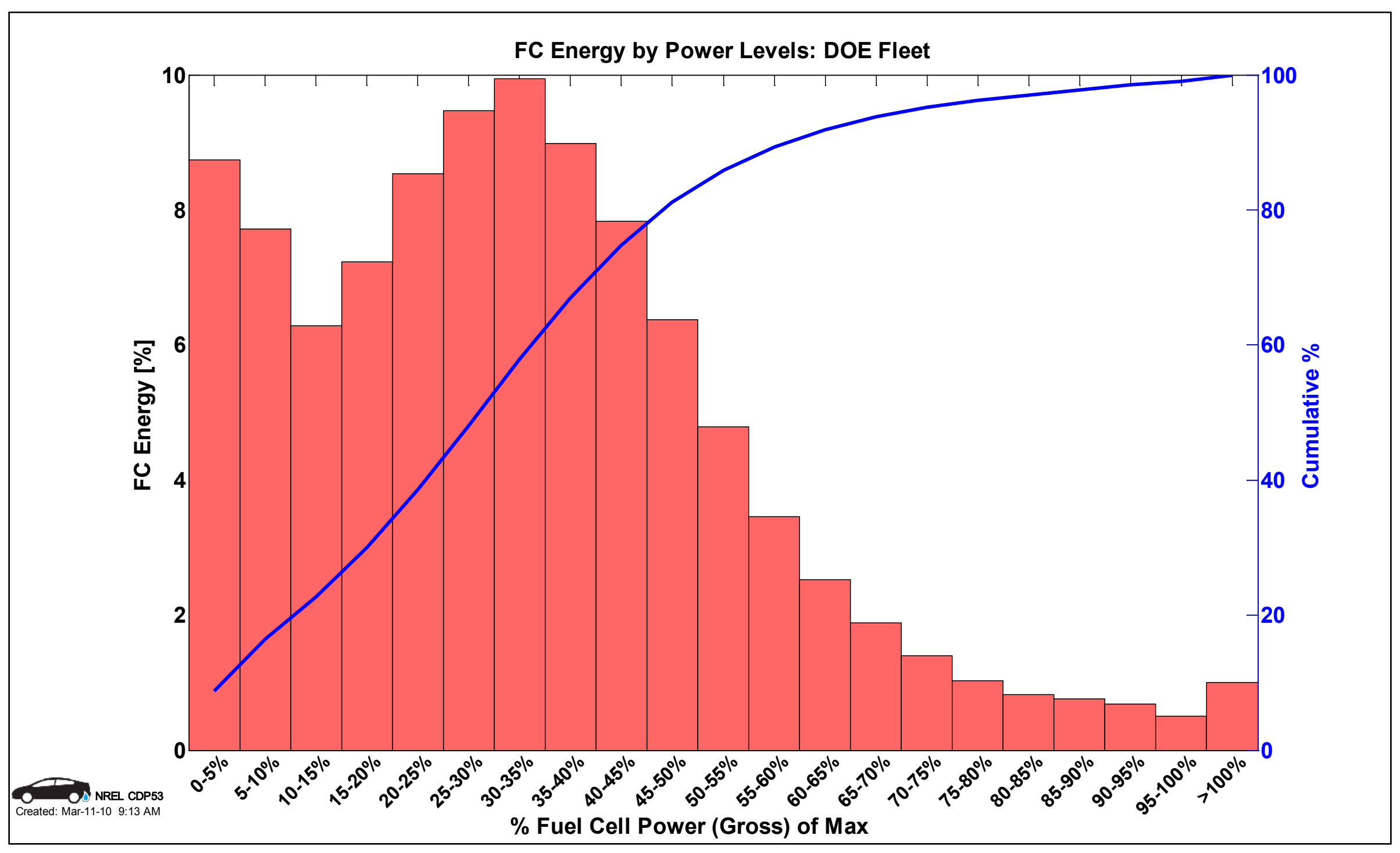




\section{CDP\#54: Time Between Trips}

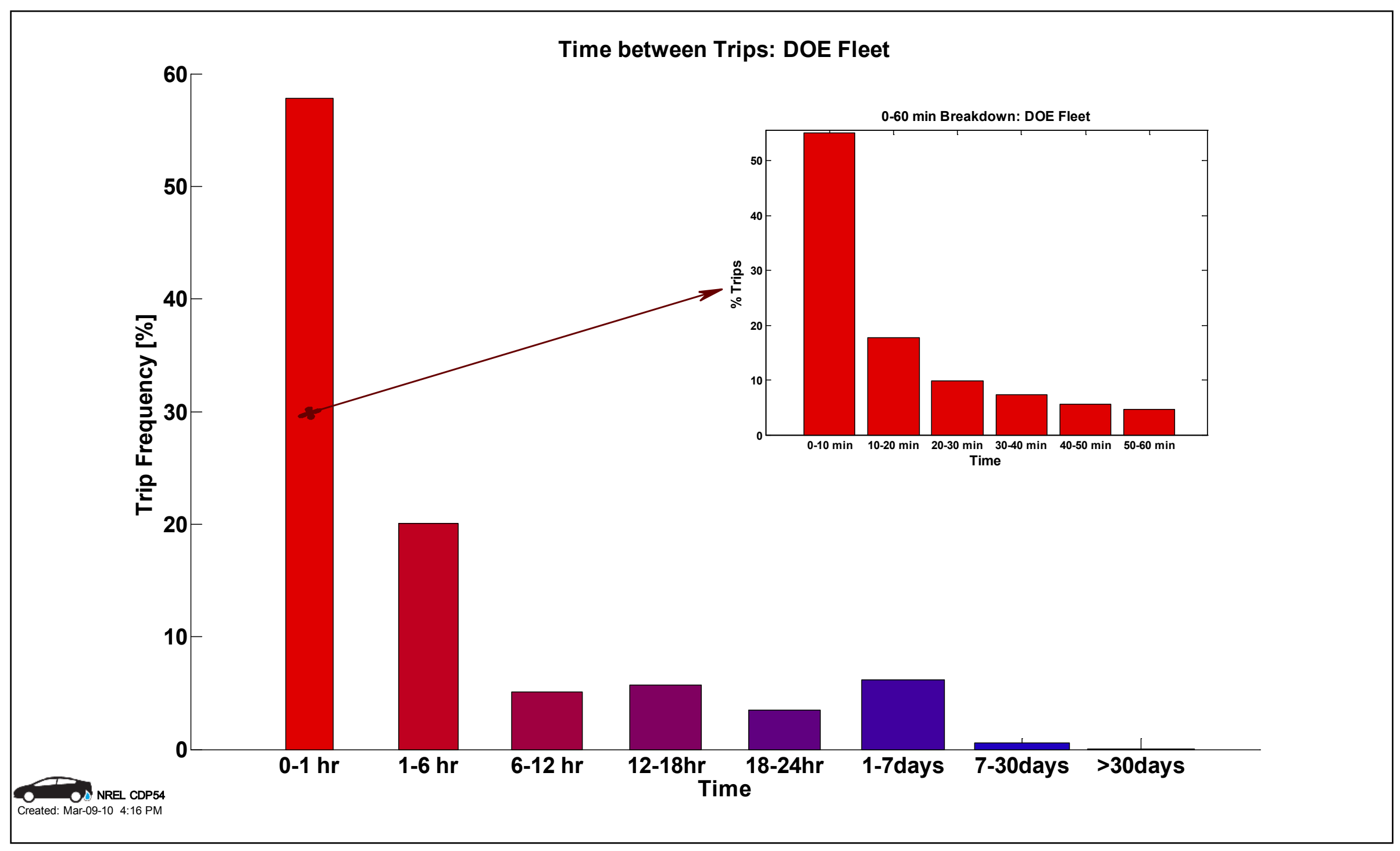




\section{CDP\#55: Fuel Cell System Energy}

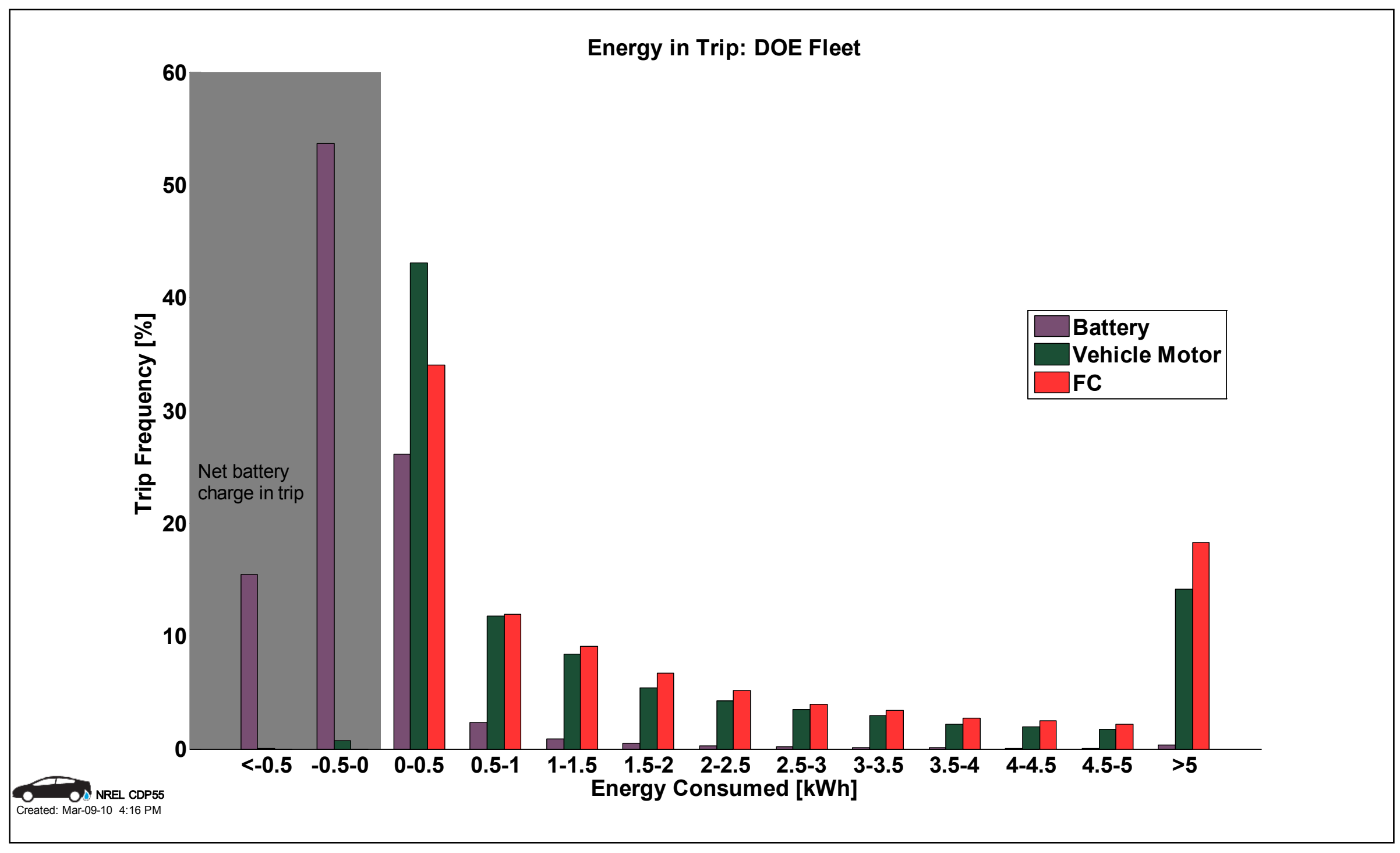




\section{CDP\#56: Daily Driving Distance}

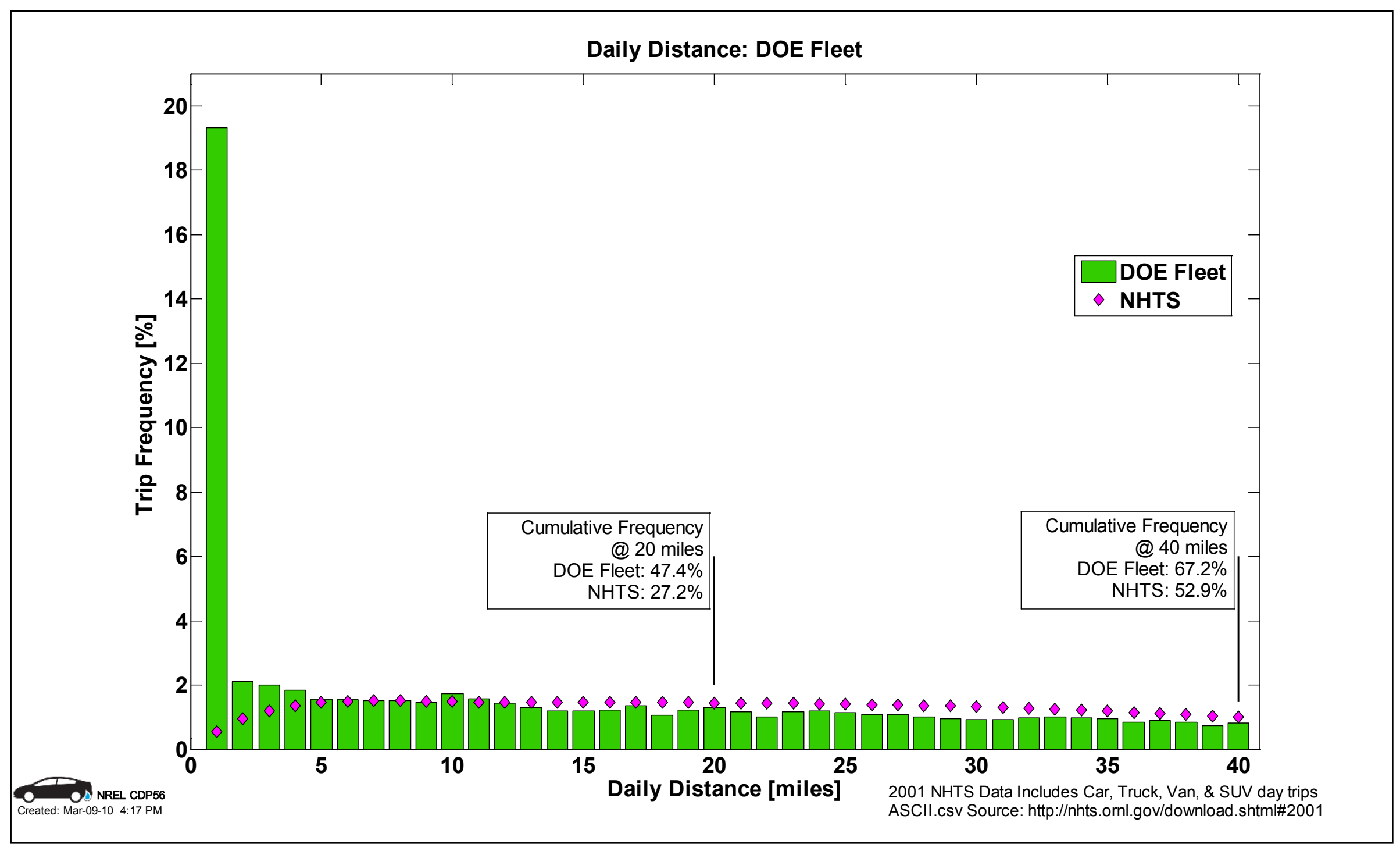




\section{CDP\#57: H2 Storage System Mass and Volume Breakdown}

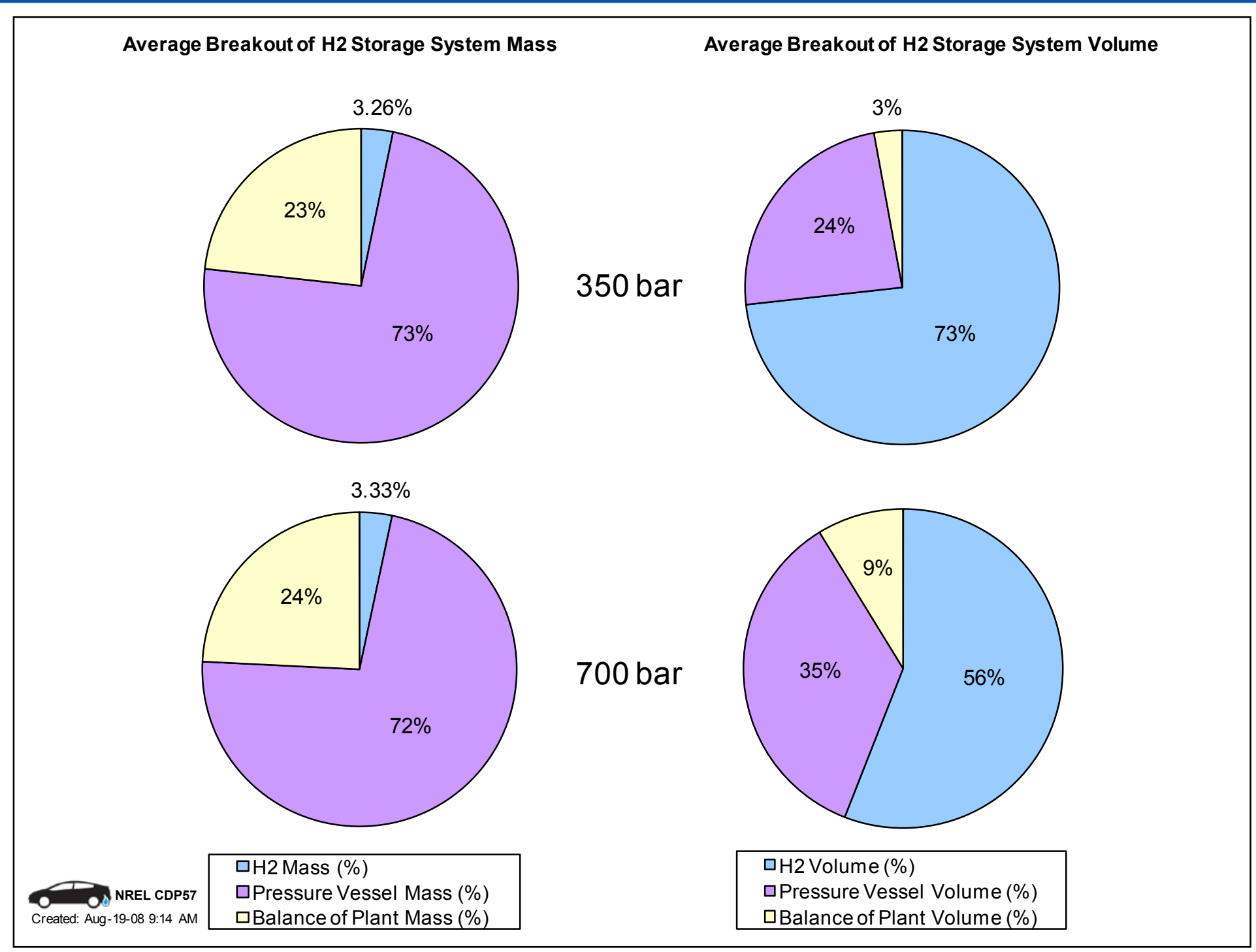




\section{CDP\#58: Fuel Cell System Power Density}

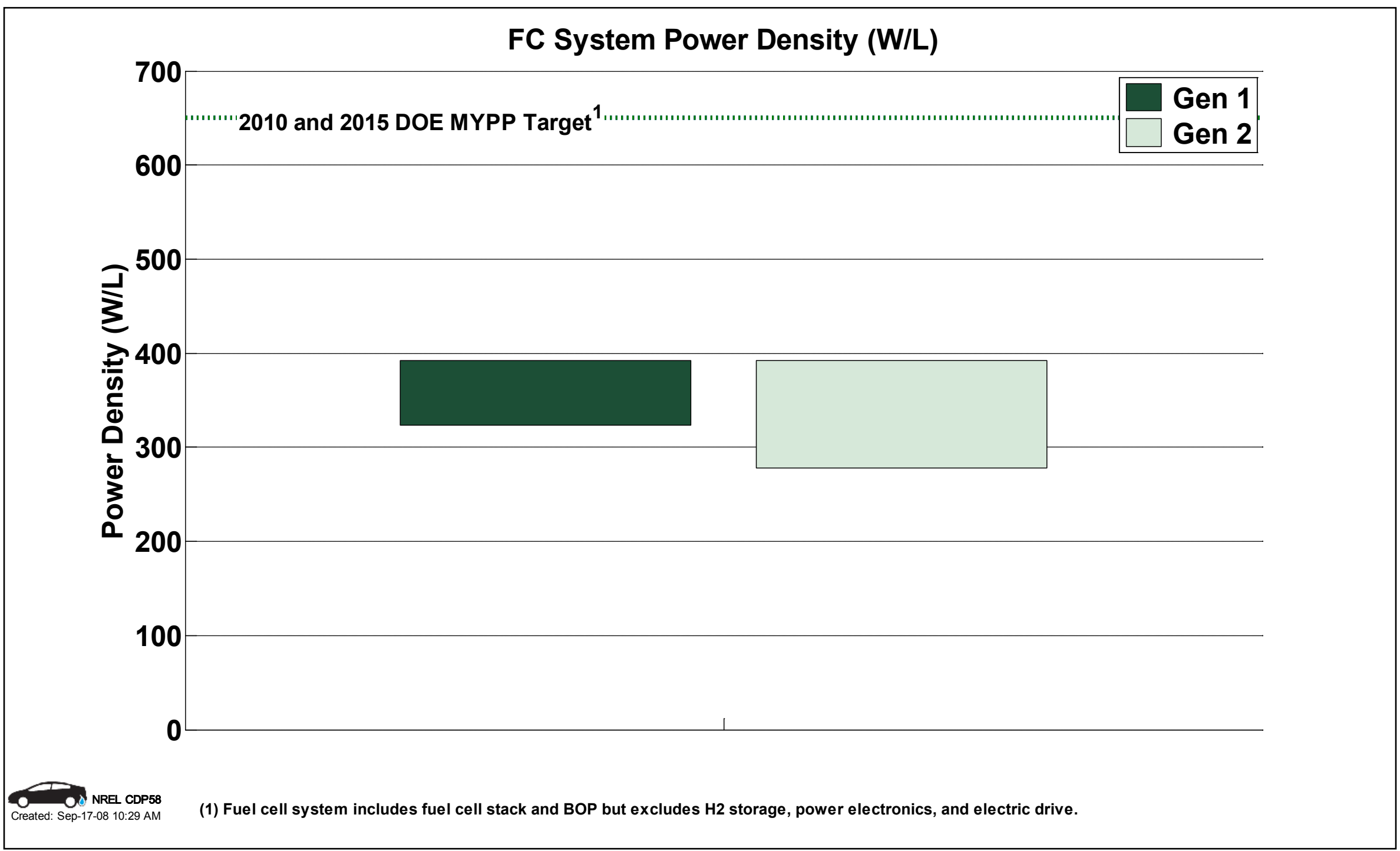




\section{CDP\#59: Fuel Cell System Specific Power}

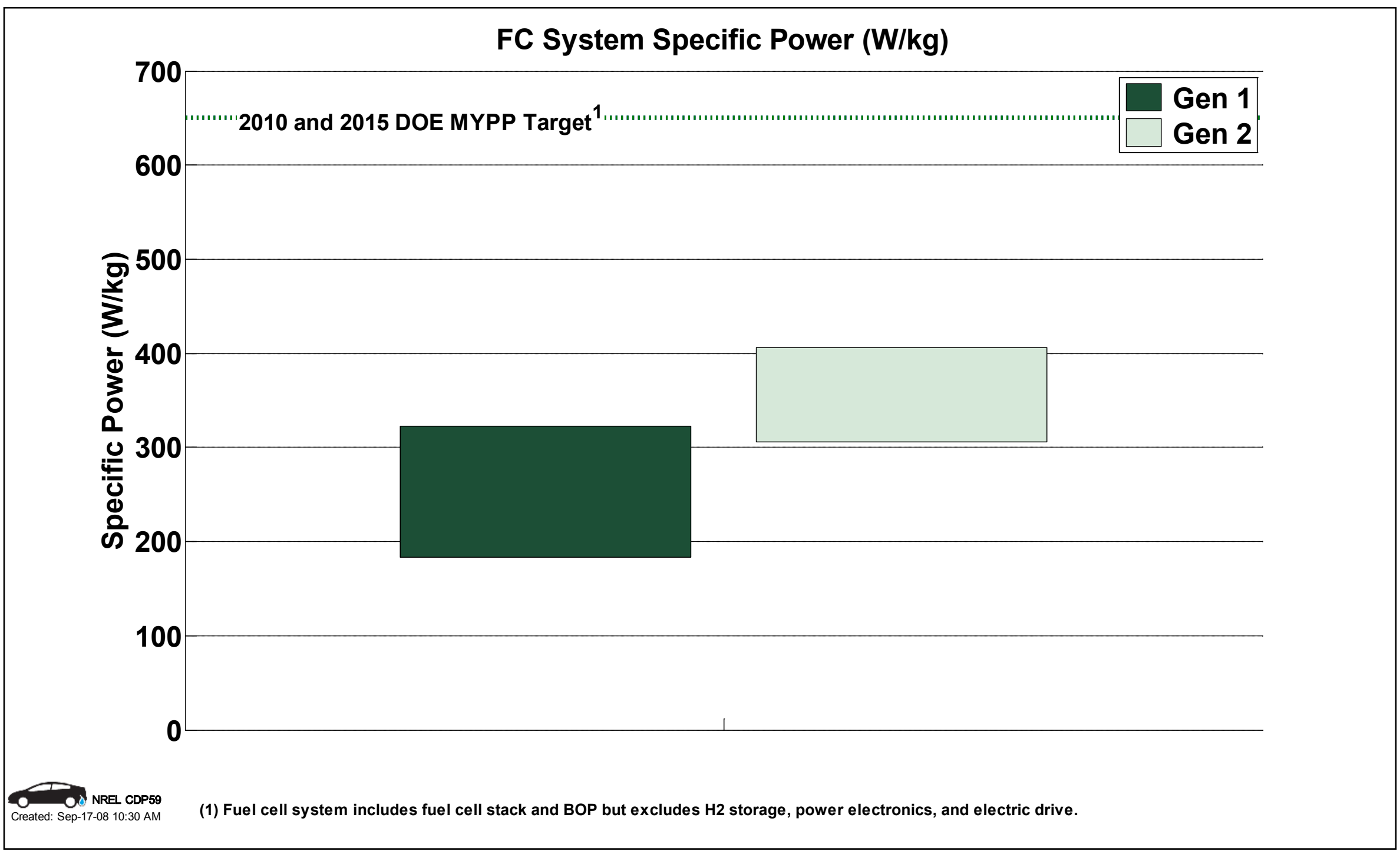




\section{CDP\#60: On-Site Hydrogen Production Efficiency vs. Capacity Utilization}

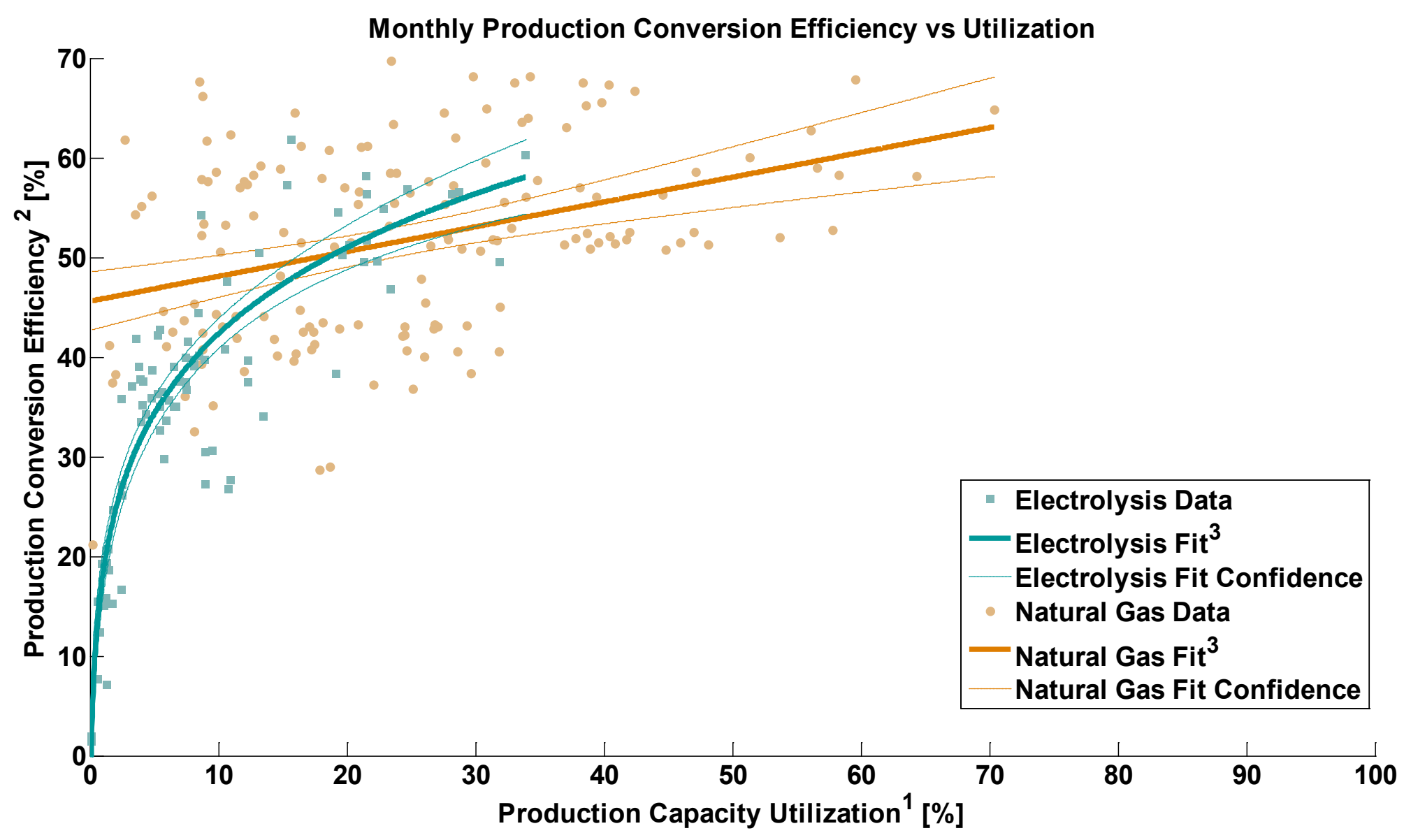

1) $100 \%$ production utilization assumes operation $24 \mathrm{hrs}$ a day, 7 days a week

2) Production conversion efficiency is defined as the energy of the hydrogen out of the process (on a LHV basis) divided by the sum of the energy into the production process from the feedstock and all other energy as needed. Conversion efficiency does not include energy used for compression, storage, and dispensing.

3) High correlation with electrolysis data $\left(R^{2}=0.82\right)$ \& low correlation with natural gas data $\left(R^{2}=0.060\right)$ 


\section{CDP\#61: Refueling Station Compressor Efficiency}

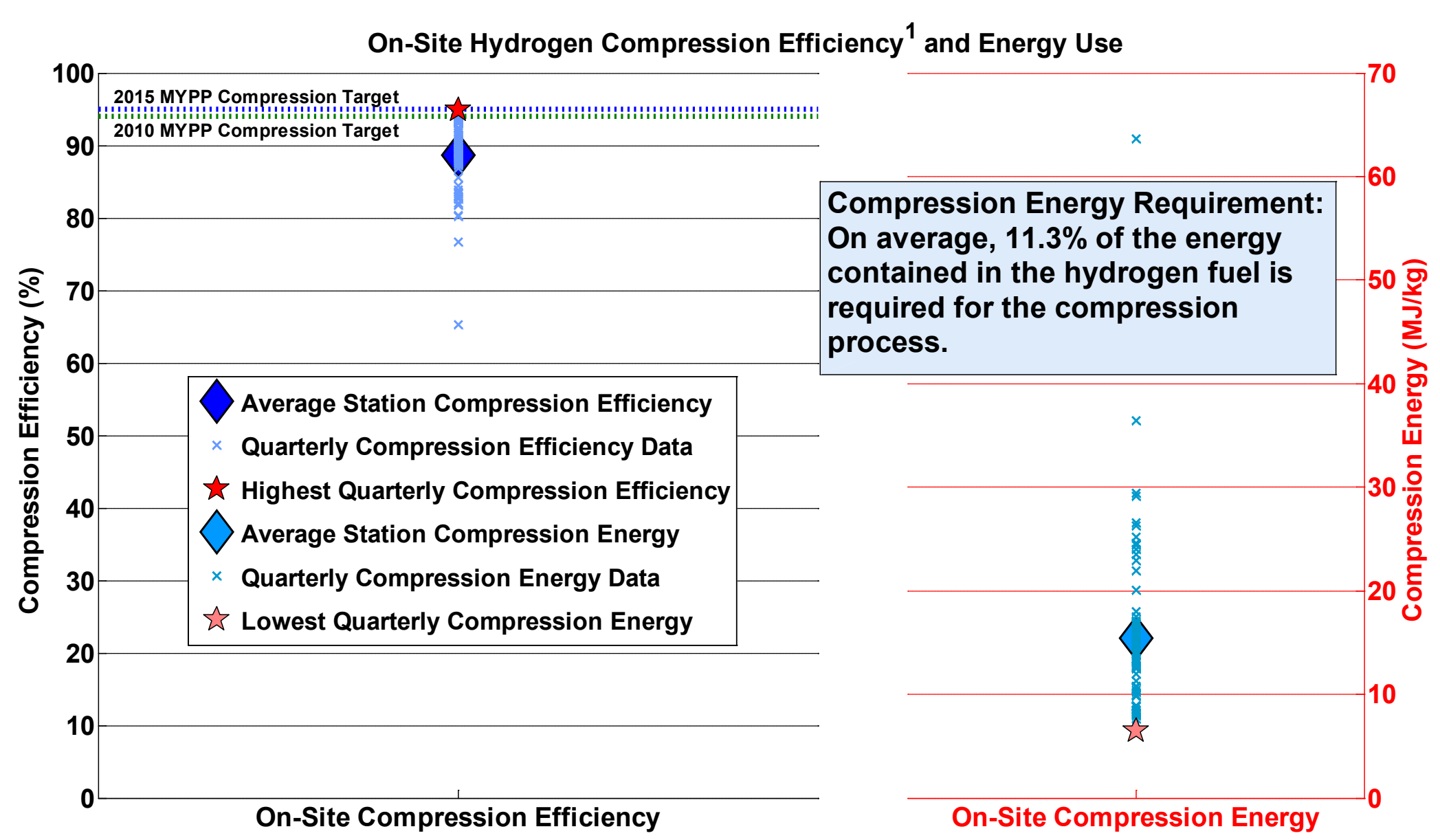

${ }^{1}$ Consistent with the MYPP, compression efficiency is defined as the energy of the hydrogen out of the process (on an LHV basis) divided by the sum of the energy of the hydrogen output plus all other energy needed for the compression process. Data shown for on-site hydrogen production and storage 


\section{CDP\#62: Learning Demonstration Vehicle Greenhouse Gas Emissions}

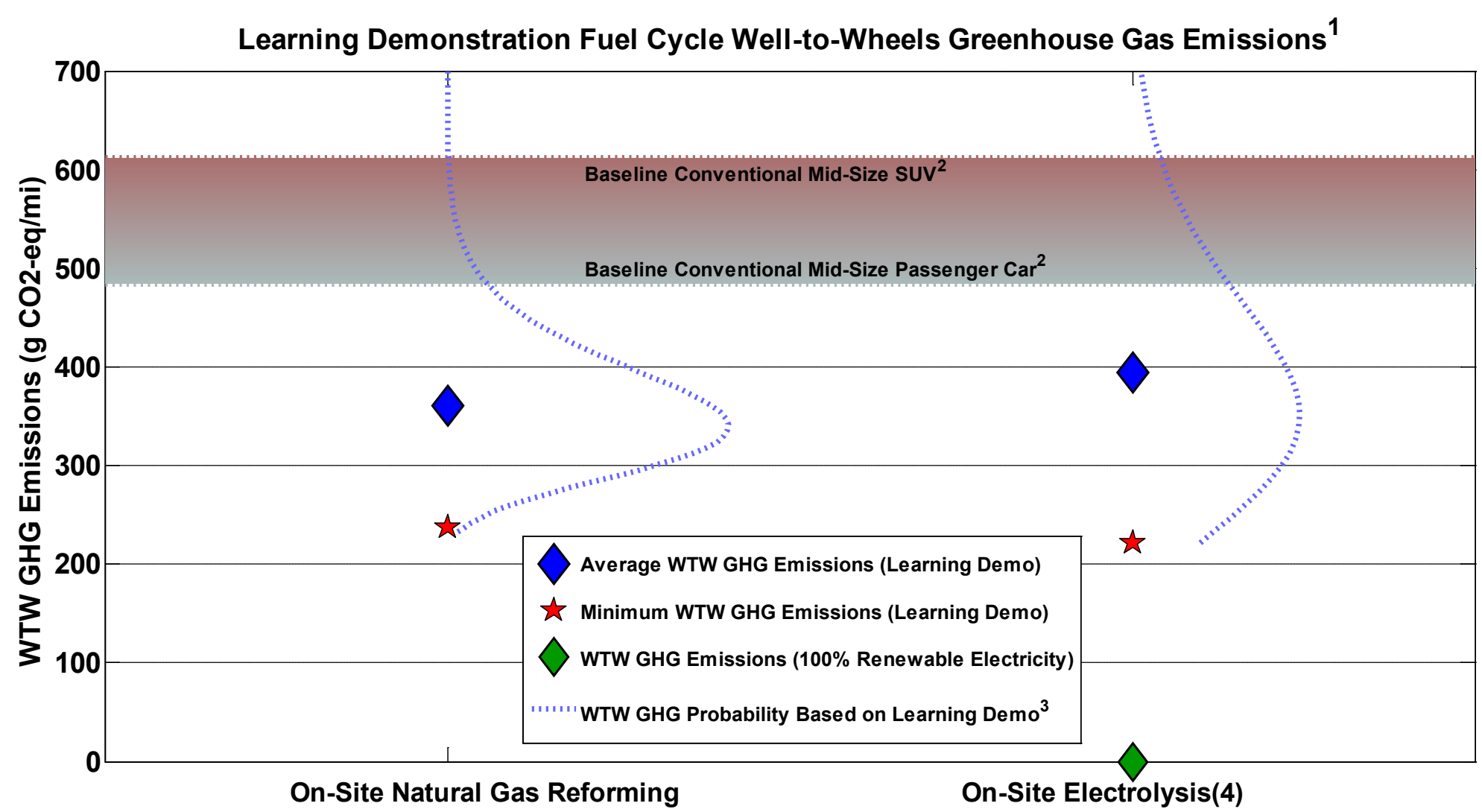

1. Well-to-Wheels greenhouse gas emissions based on DOE's GREET model, version 1.8b. Analysis uses default GREET values except for FCV fuel economy, hydrogen production conversion efficiency, and electricity grid mix. Fuel economy values are the Gen 1 and Gen 2 window-sticker fuel economy data for all teams (as used in CDP \#6); conversion efficiency values are the production efficiency data used in CDP \#13.

2. Baseline conventional passenger car and light duty truck GHG emissions are determined by GREET 1.8b, based on the EPA window-sticker fuel economy of a conventional gasoline mid-size passenger car and mid-size SUV, respectively. The Learning Demonstration fleet includes both passenger cars and SUVs.

3. The Well-to-Wheels GHG probability distribution represents the range and likelihood of GHG emissions resulting from the hydrogen FCV fleet based on window-sticker fuel economy data and monthly conversion efficiency data from the Learning Demonstration. 4. On-site electrolysis GHG emissions are based on the average mix of electricity production used by the Learning Demonstration production sites, which includes both
NREI CDP62 grid-based electricity and renewable on-site solar electricity. GHG emissions associated with on-site production of hydrogen from electrolysis are highly dependent on

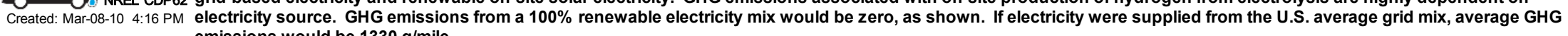
emissions would be $1330 \mathrm{~g} / \mathrm{mile}$. 


\section{CDP\#63: Hydrogen Fueling Station Maintenance by System}

Hydrogen Fueling Station Maintenance

By Number of Events

Total Number of Events $=2491$

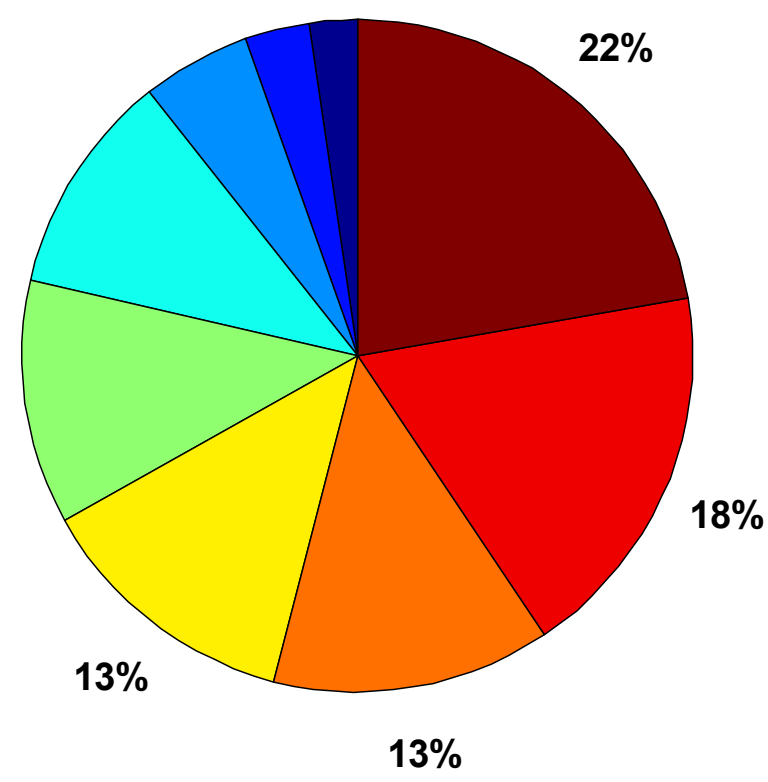

By Labor Hours

Total Hours $=11430$

\begin{tabular}{|l|}
\hline system control \& safety \\
\hline compressor \\
$\square$ reformer \\
$\square$ electrolyzer \\
$\square$ dispenser \\
$\square$ other \\
valves \& piping \\
electrical \\
storage \\
\hline
\end{tabular}

$20 \%$

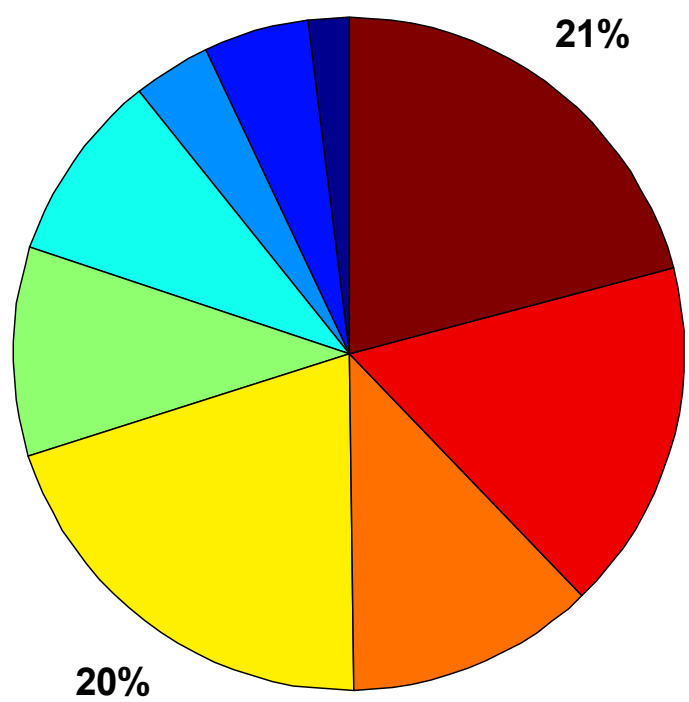

$12 \%$ 


\section{CDP\#64: Fuel Cell Vehicle Maintenance by}

System

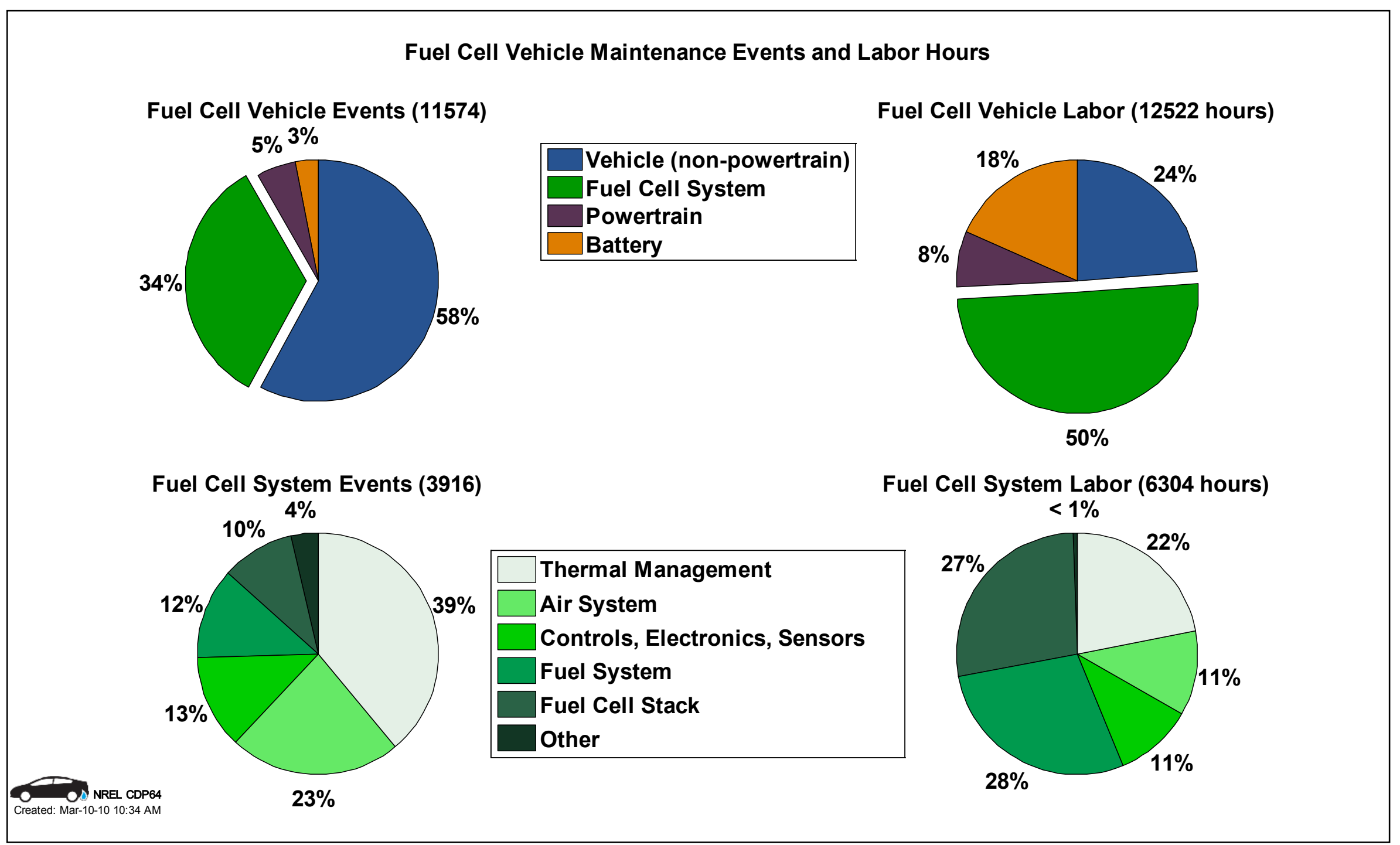




\section{CDP\#65: Percent Idle in Trip with Comparison to Standard Drive Cycles}

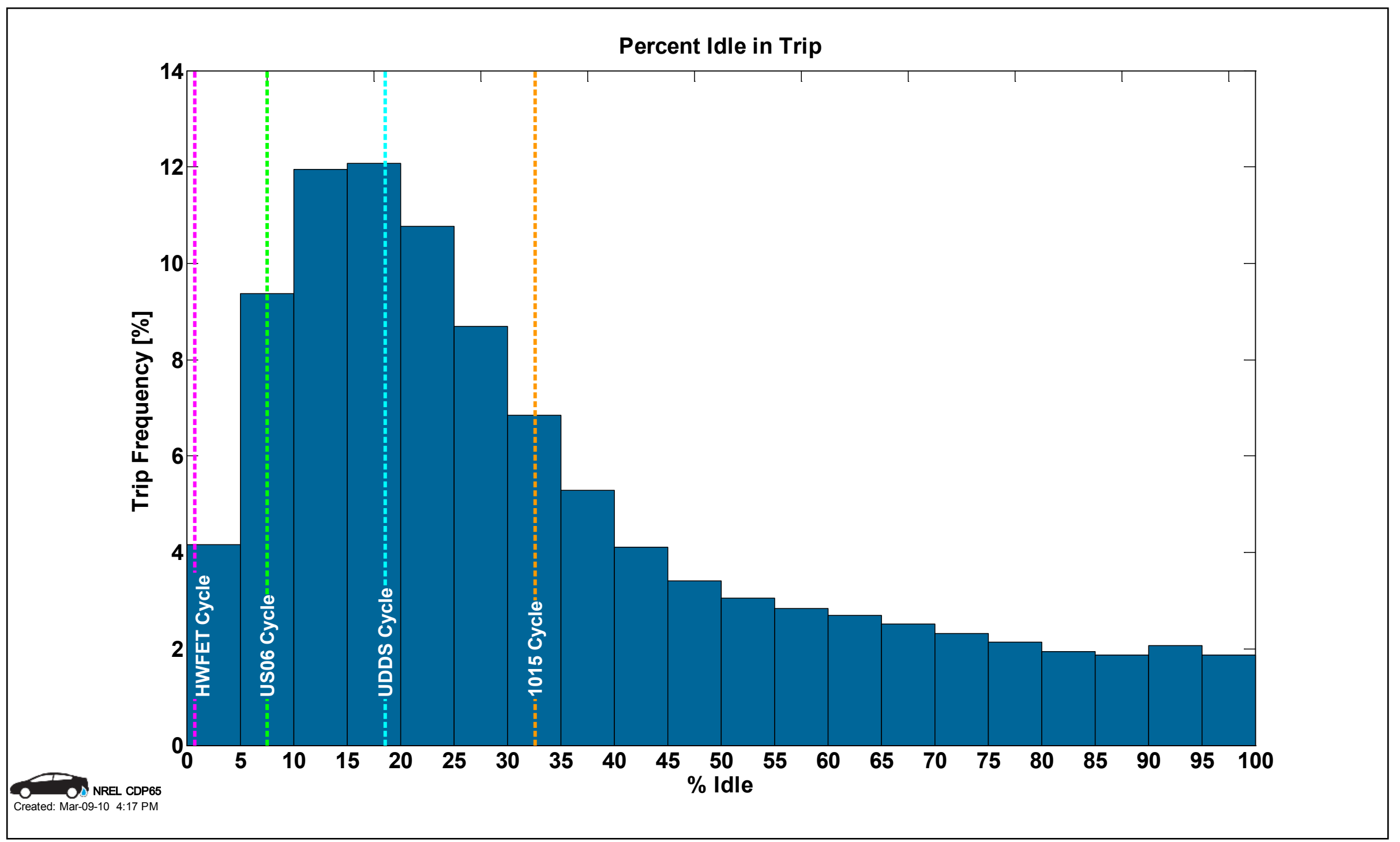




\section{CDP\#66: FCV Speed with Comparison to Standard Drive Cycles}

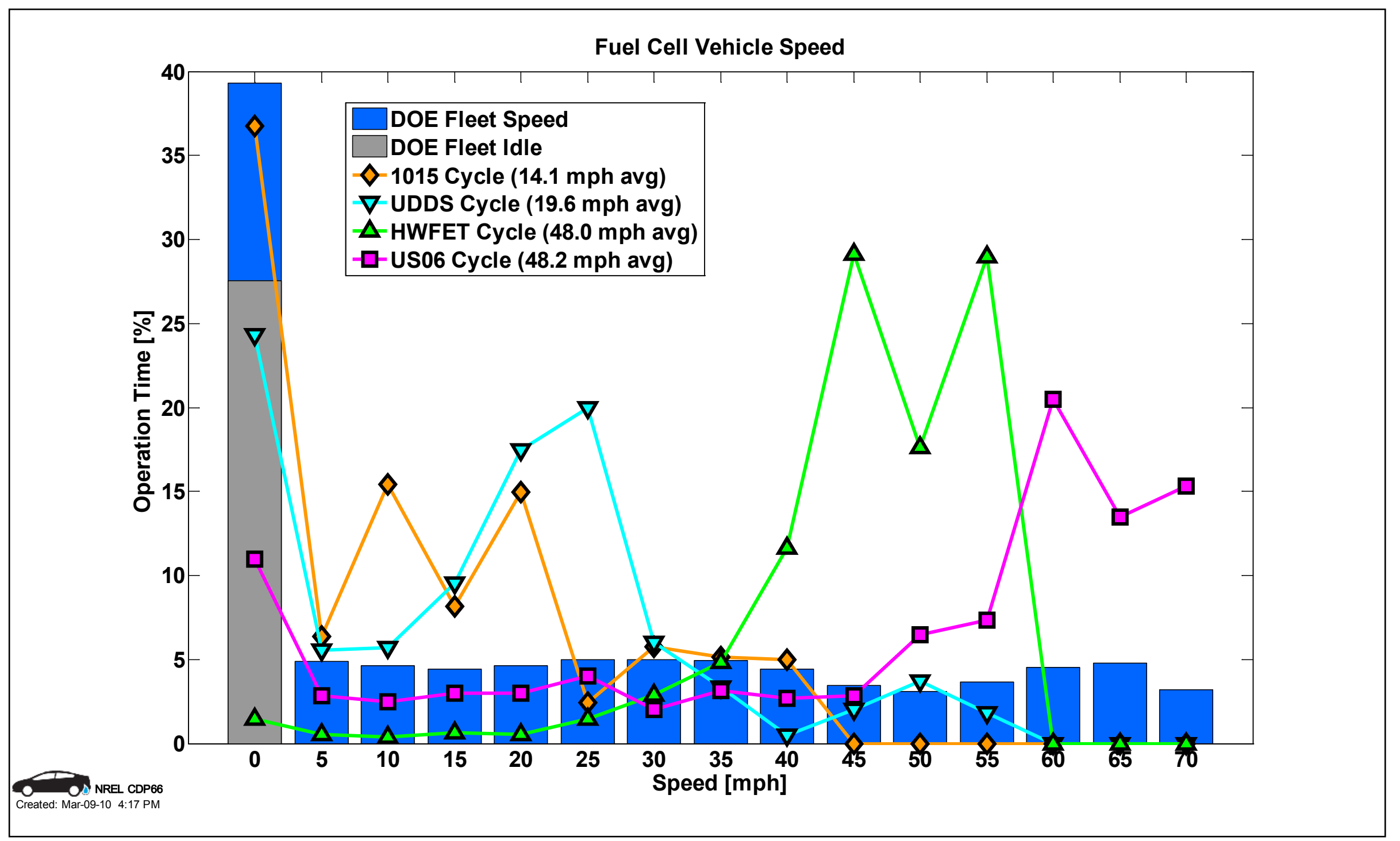




\section{CDP\#67: Fuel Cell Stack Operation Hours}

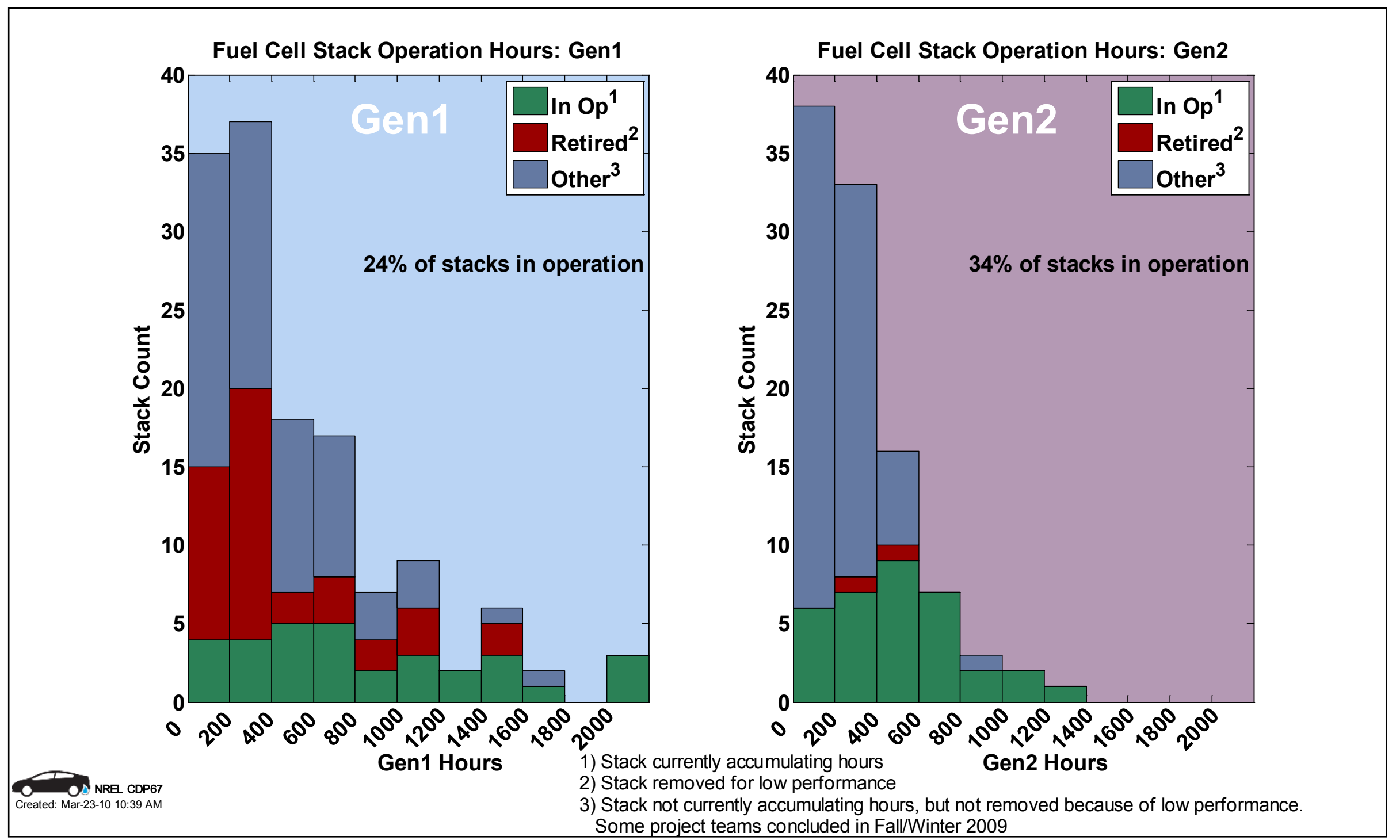




\section{CDP\#68: Power Drop During Fuel Cell Stack Operation Period}

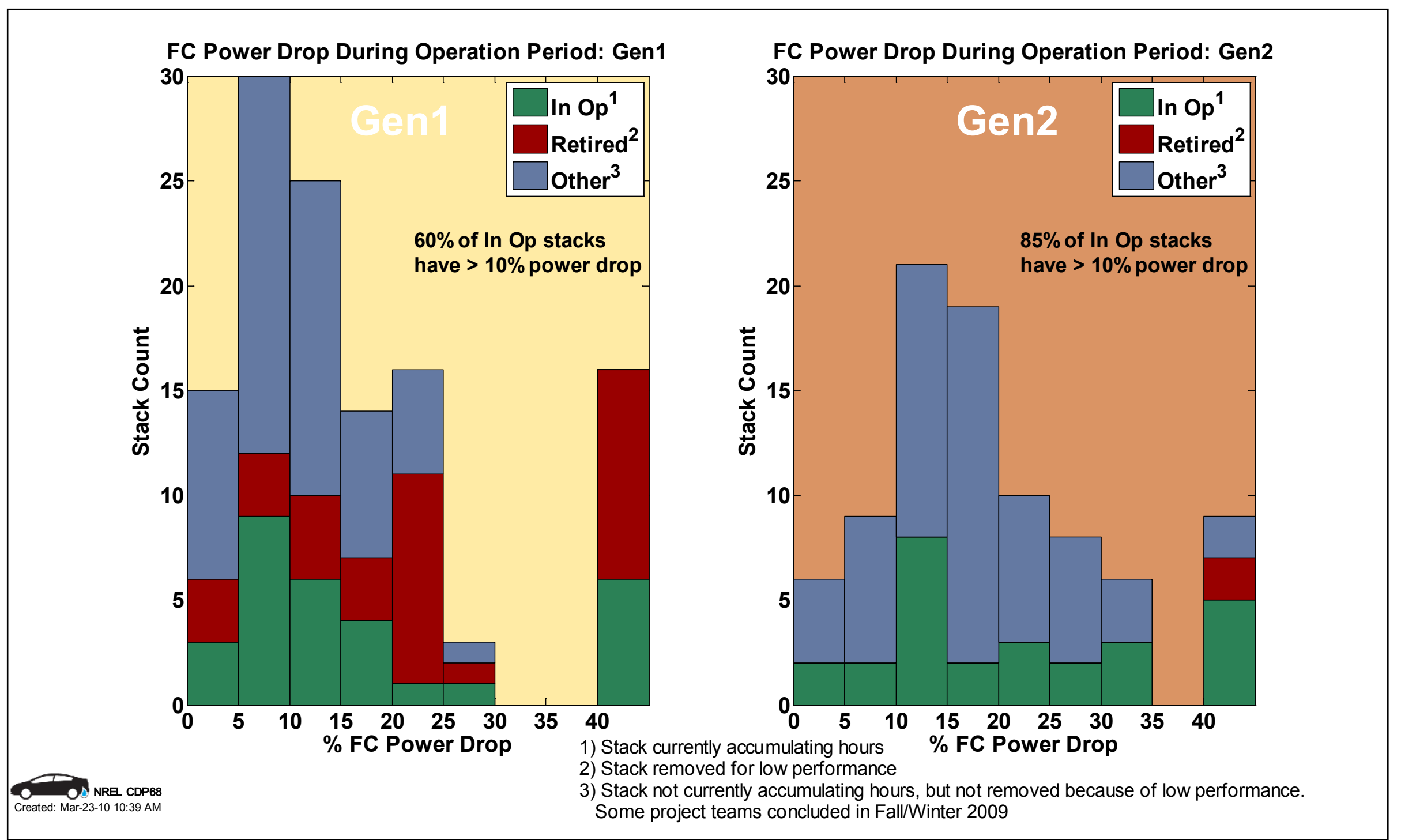




\section{CDP\#69: Max Fuel Cell Power Degradation -}

Gen 1

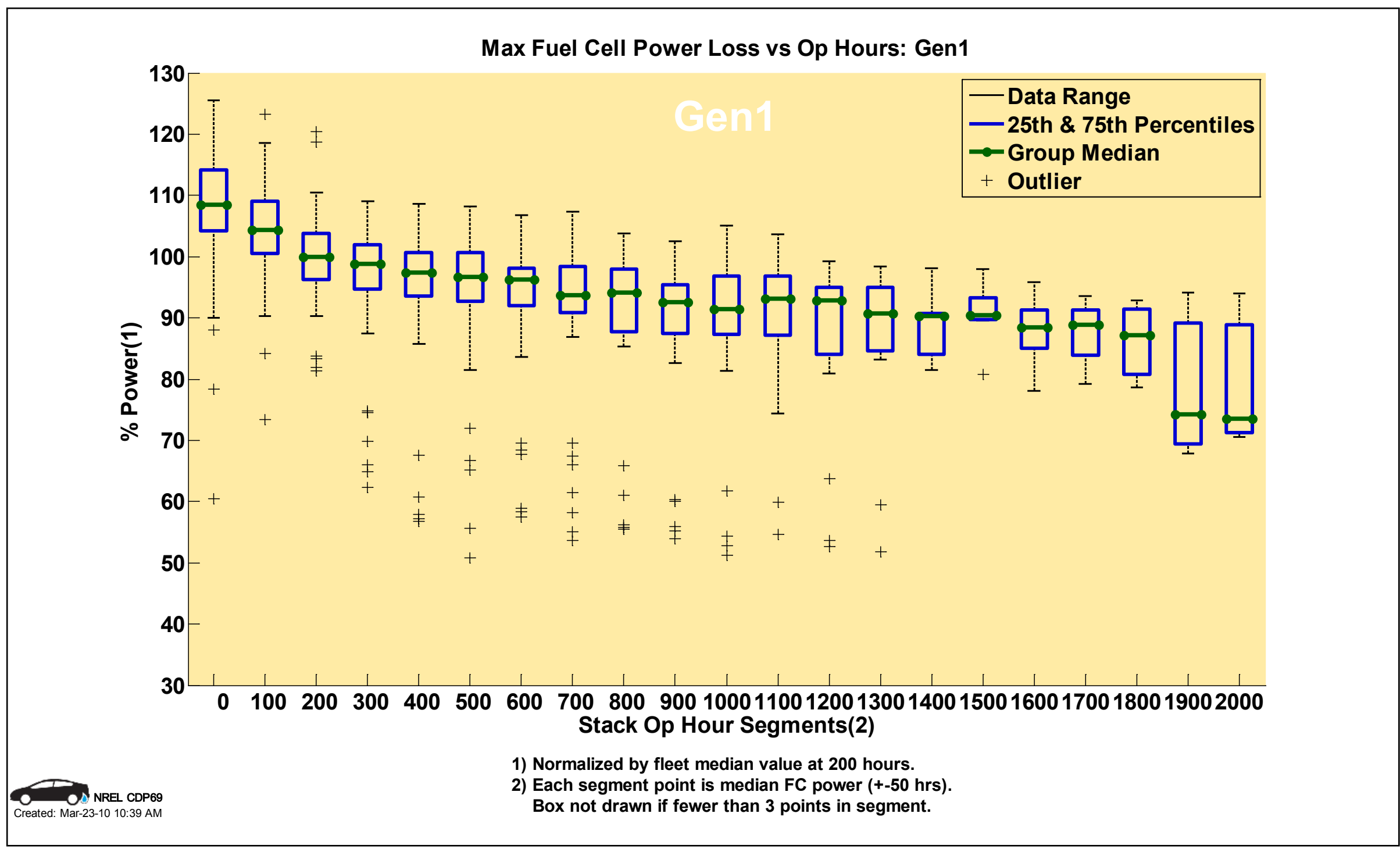




\section{CDP\#71: Projected Hours to OEM Low Power Operation Limit}

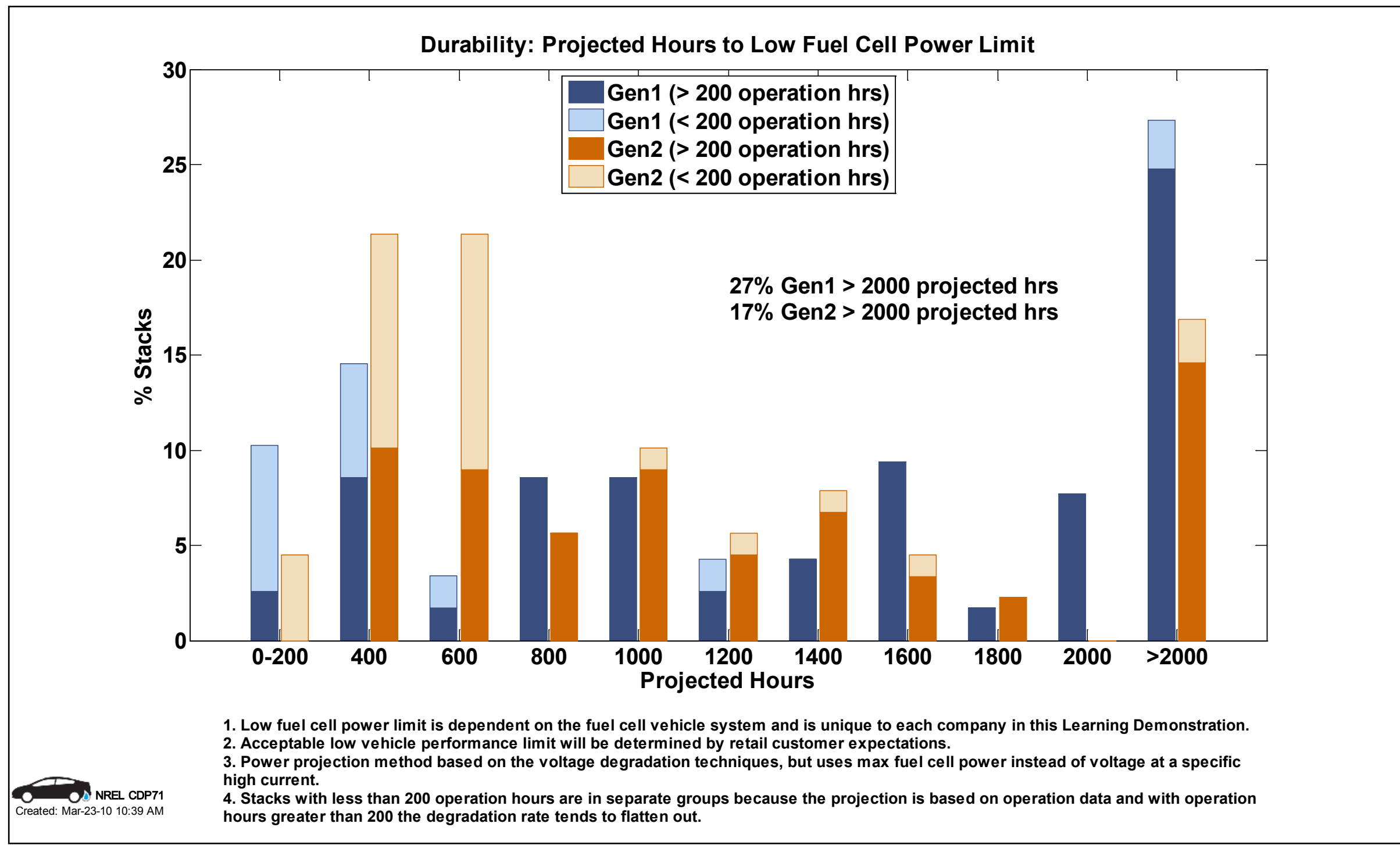




\section{CDP\#72: Difference Between Tank and Ambient Temperature Prior to Refueling}

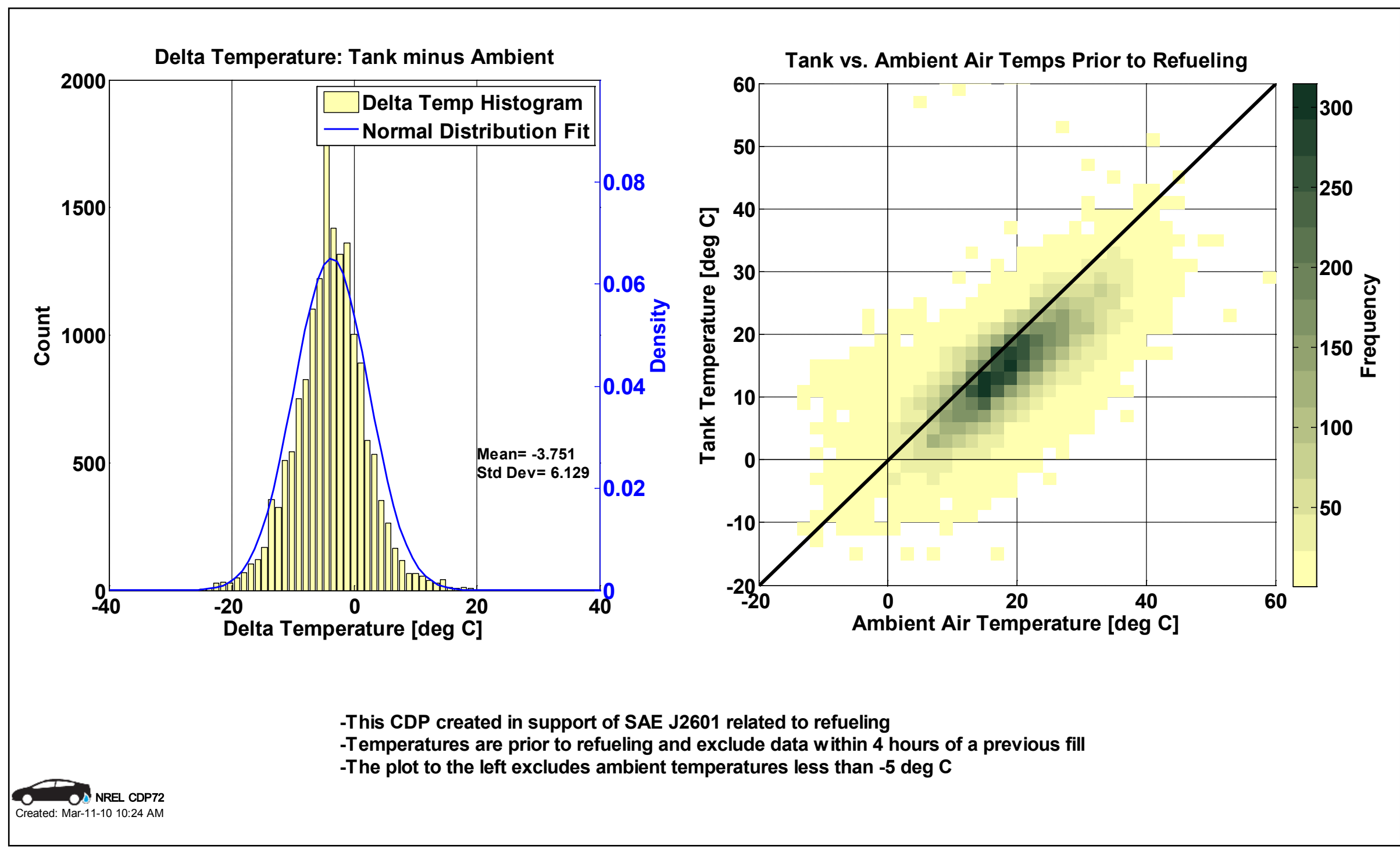




\section{CDP\#73: Fuel Cell Stack Projected Hours as a Function of Voltage Drop}

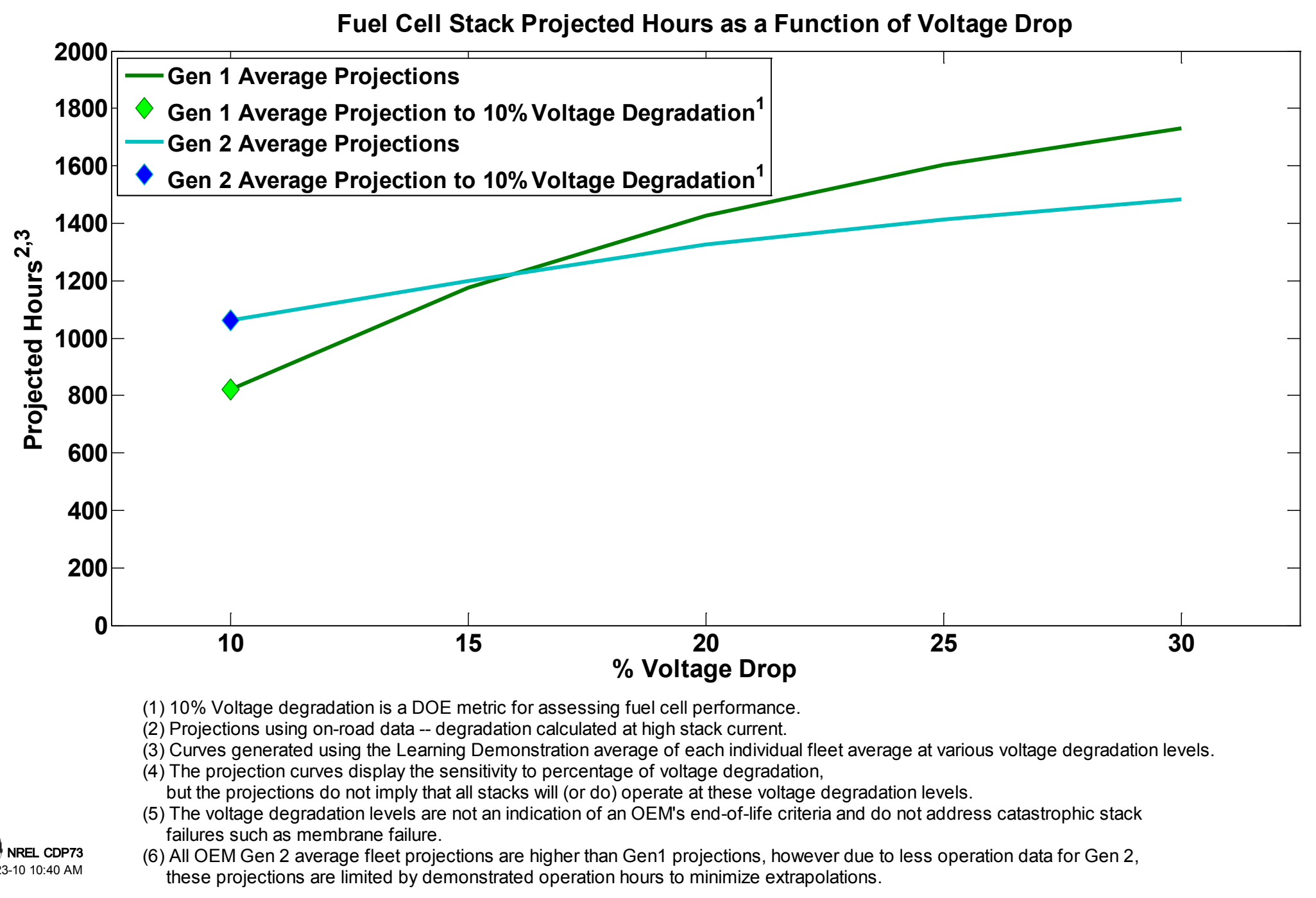




\section{CDP\#74: Fuel Cell Transient Cycle Count per Mile and per Minute}
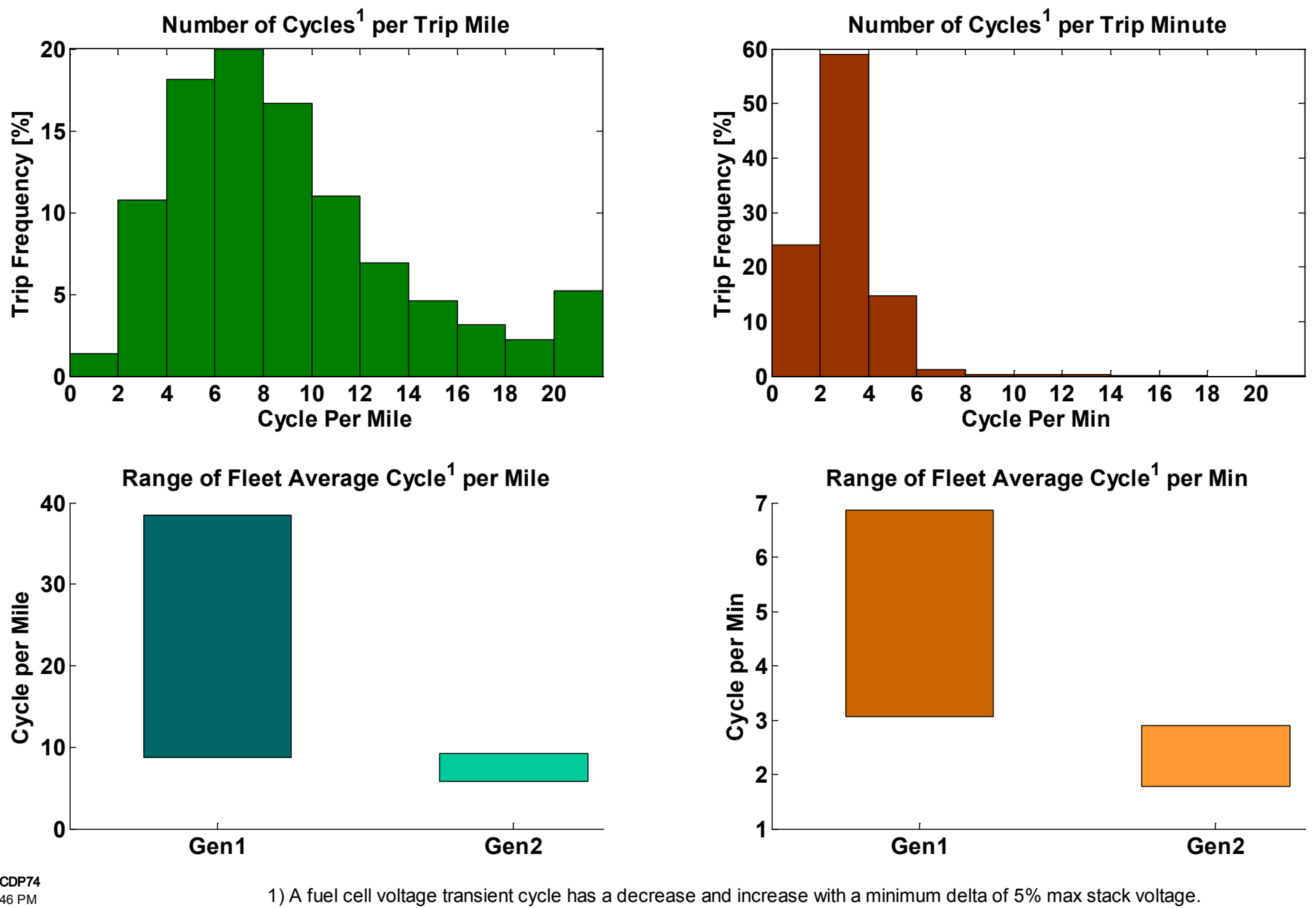


\section{CDP\#75: Fuel Cell Transient Voltage and Time Change}

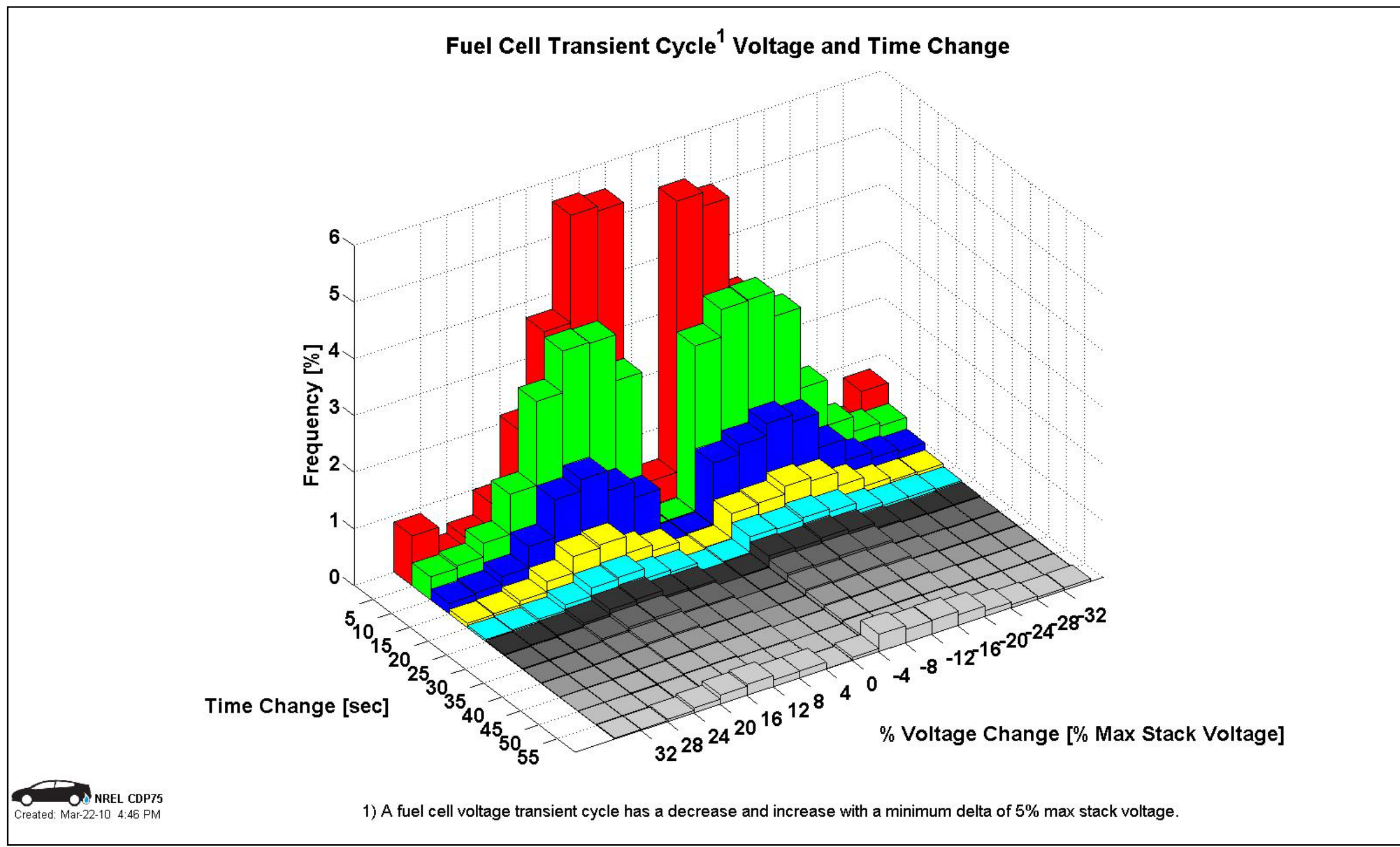




\section{CDP\#76: Fuel Cell Transient Rate by Cycle Category}
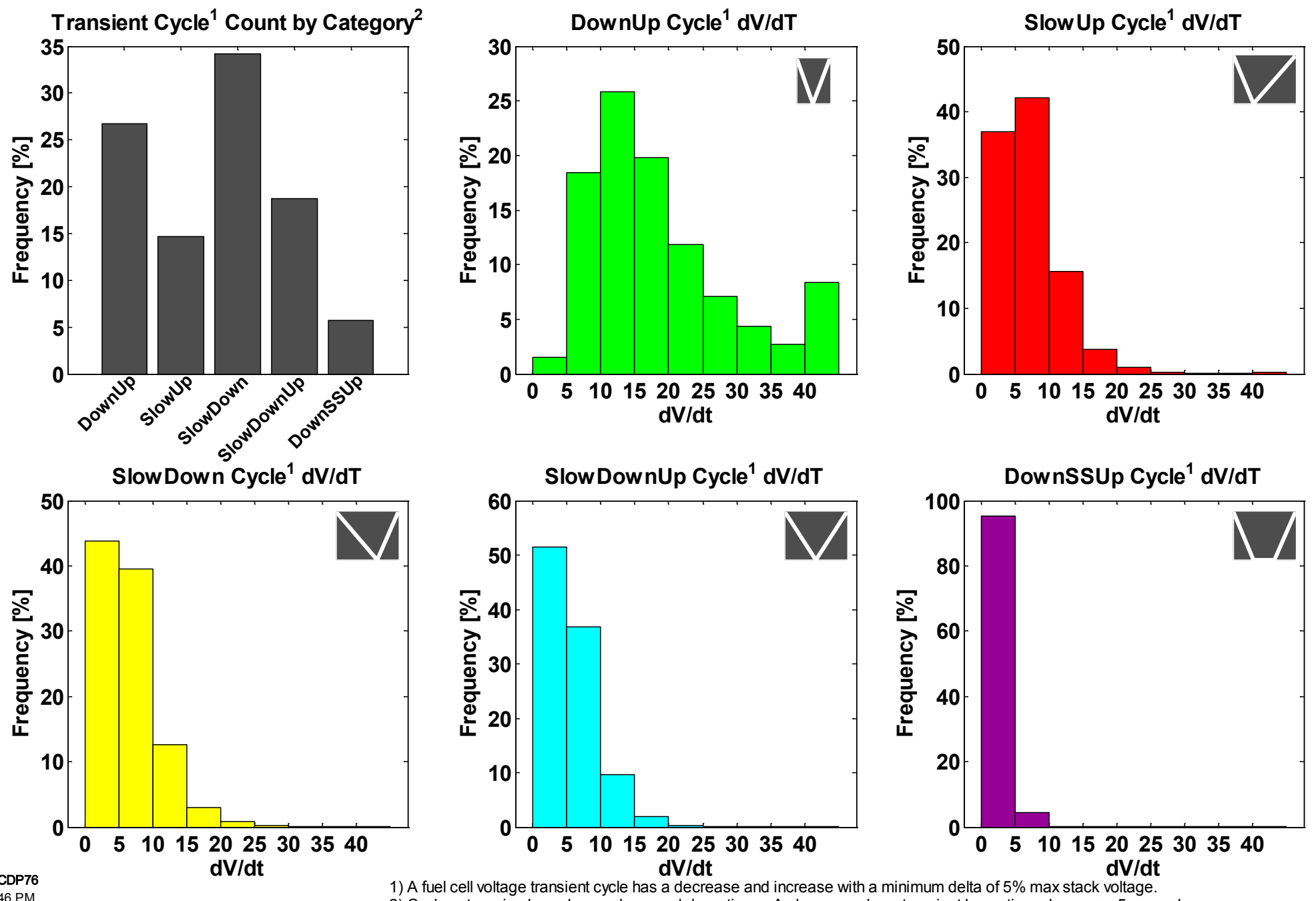

A fuel cell voltage transient cycle has a decrease and increase with a minimum delta of $5 \%$ max stack voltage.

2) Cycle categories based on cycle up and down times. A slow up or down transient has a time change $>=5$ seconds.
SS = Steady State, where the time change is $>=10$ seconds and the voltage change is $<=2.5 \%$ max stack voltage. 


\section{CDP\#77: Fuel Cell Transient Voltage Changes by Cycle Category}
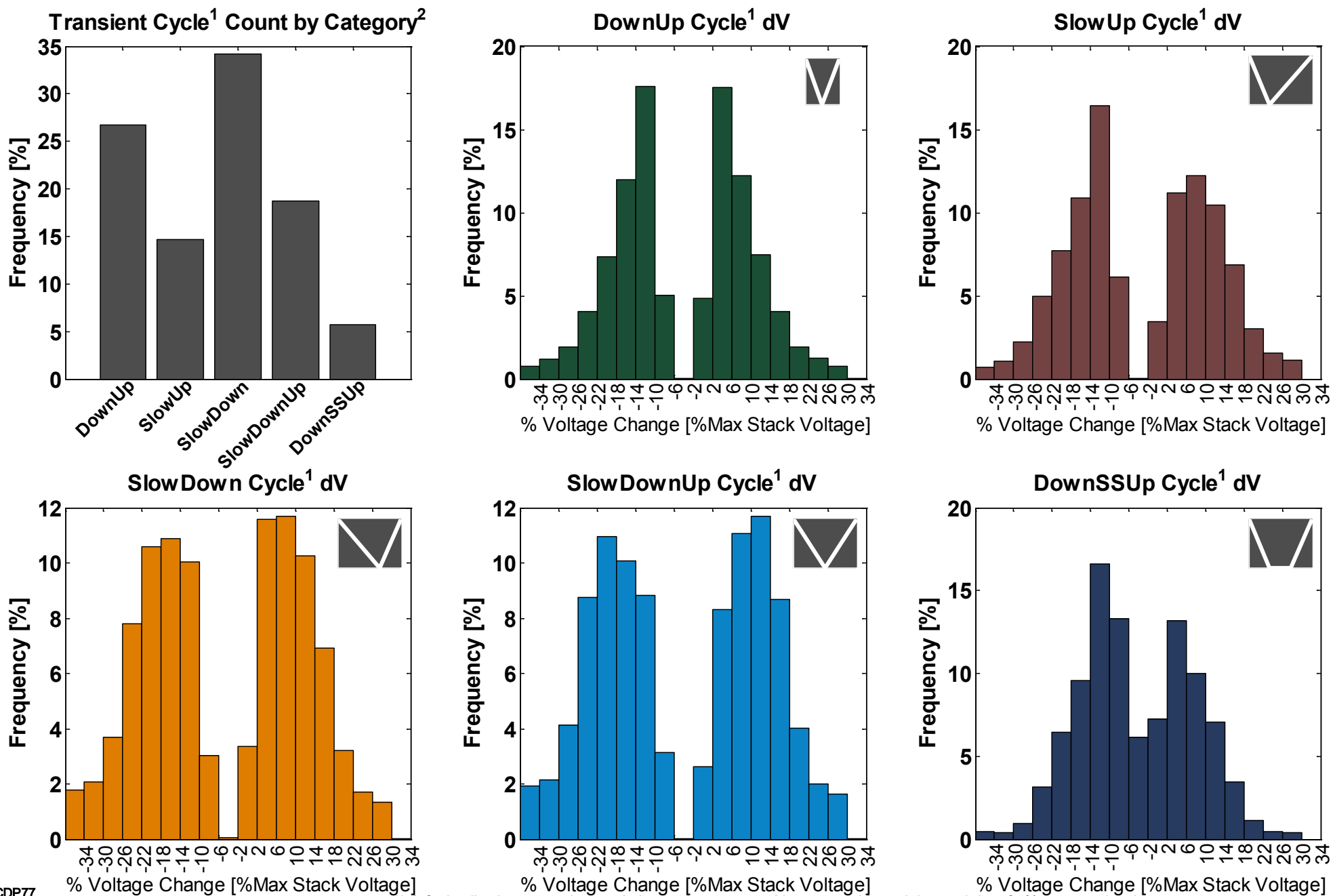

) A fuel cell voltage transient cycle has a decrease and increase with a minimum delta of $5 \%$ max stack voltage.

) Cycle categories based on cycle up and down times. A slow up or down transient has a time change $>=5$ seconds. SS $=$ Steady State, where the time change is $>=10$ seconds and the voltage change is $<=2.5 \%$ max stack voltage 


\section{CDP\#78: Fuel Cell Transient Cycles Outside of Specified Voltage Levels}

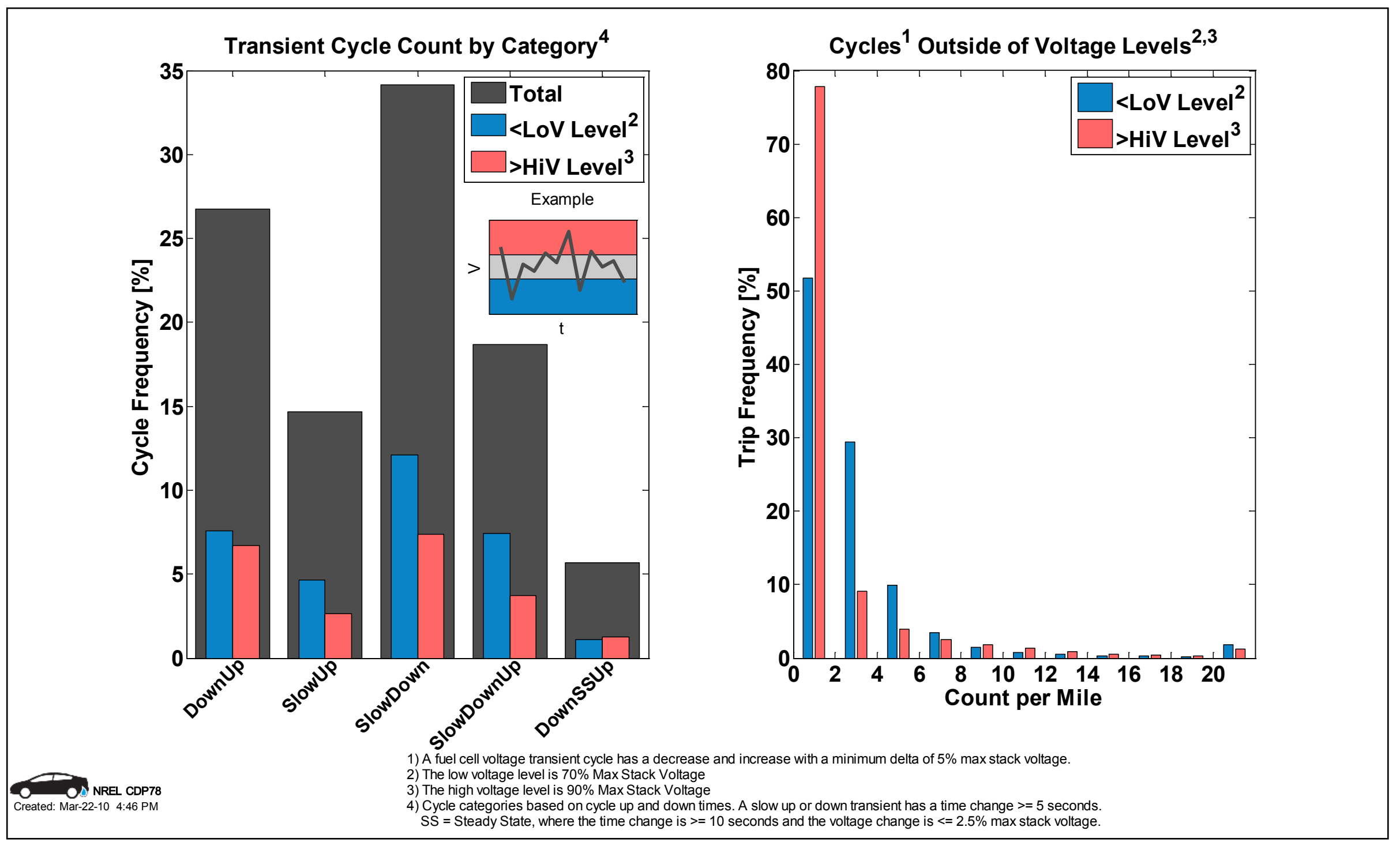




\section{CDP\#79: Percentage of Trip Time at Steady State}

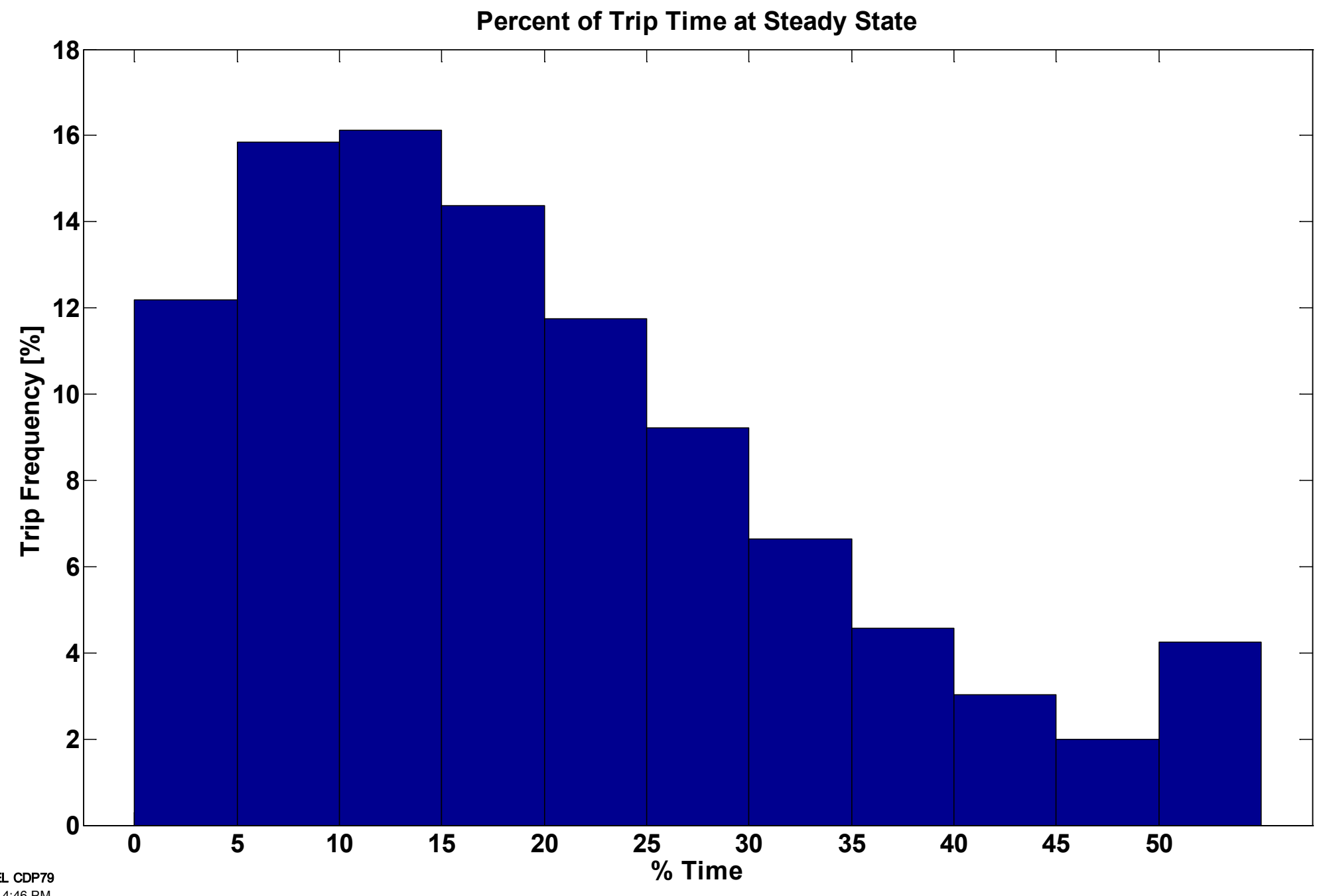

1) $S S=$ Steady State, where the time change is $>=10$ seconds and the voltage change is $<=2.5 \%$ max stack voltage 


\section{CDP\#80: Miles Between Refuelings}

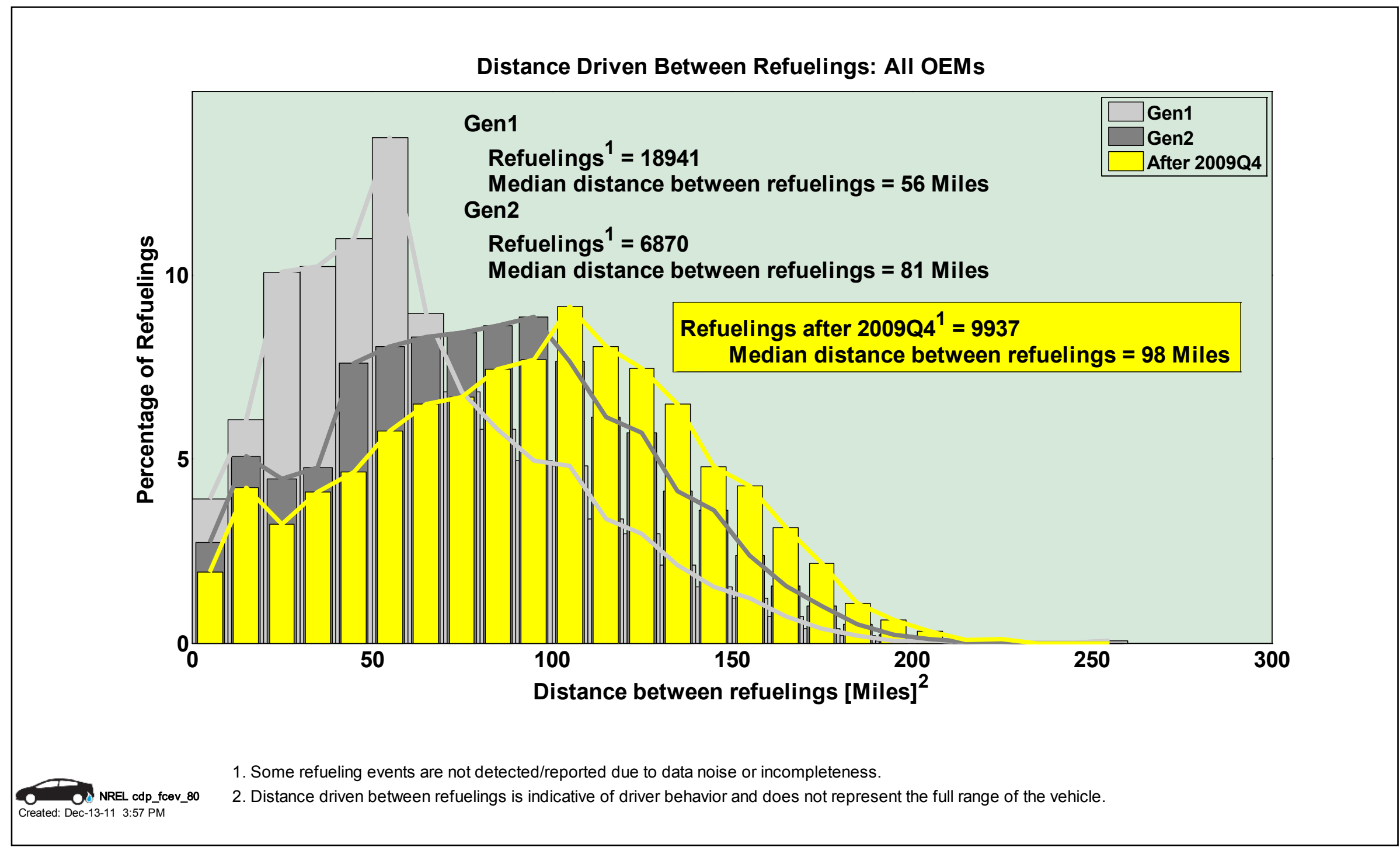




\section{CDP\#81: Average Trip Speed}

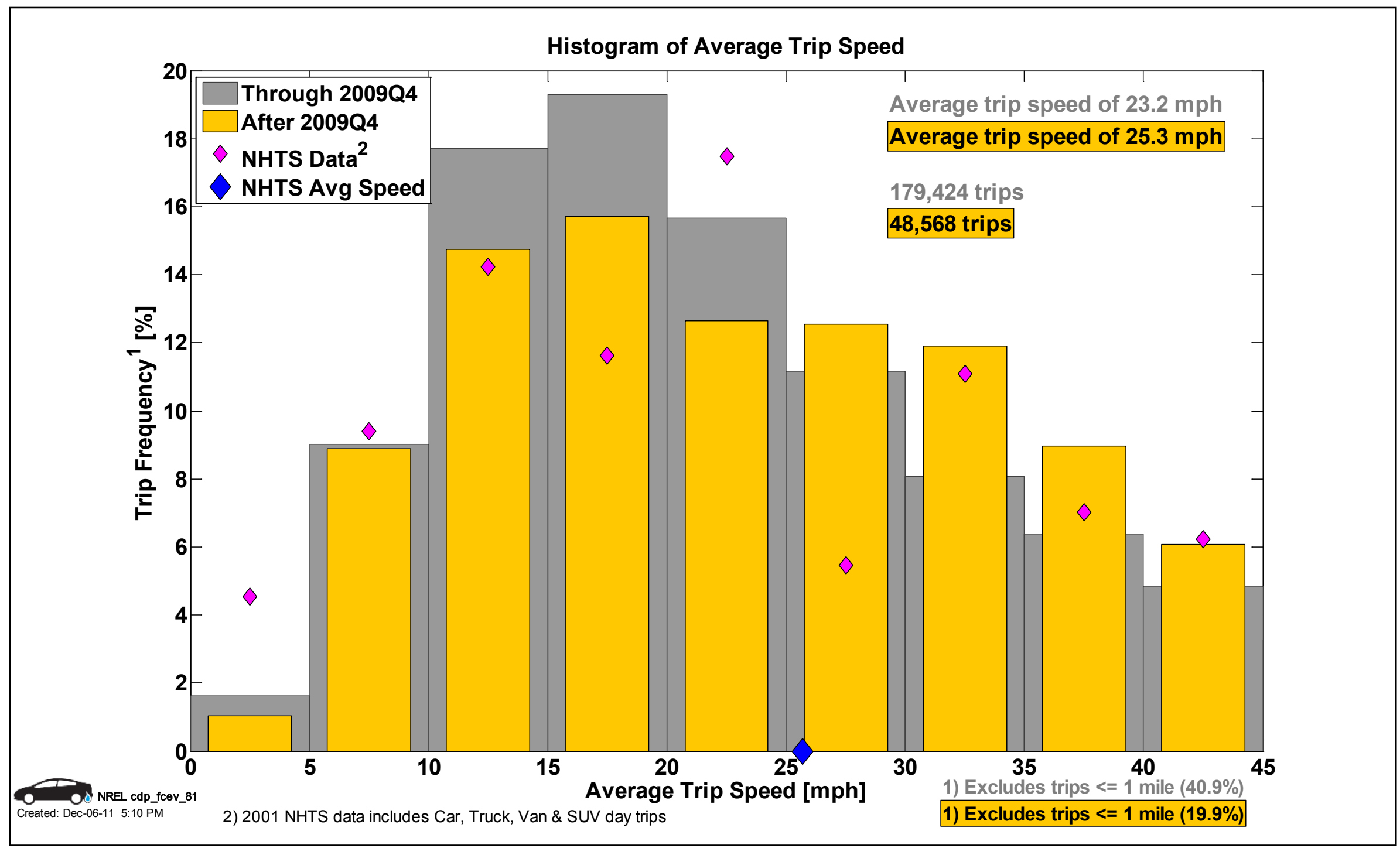




\section{CDP\#82: Daily FC Operation Hours in Automotive Application}

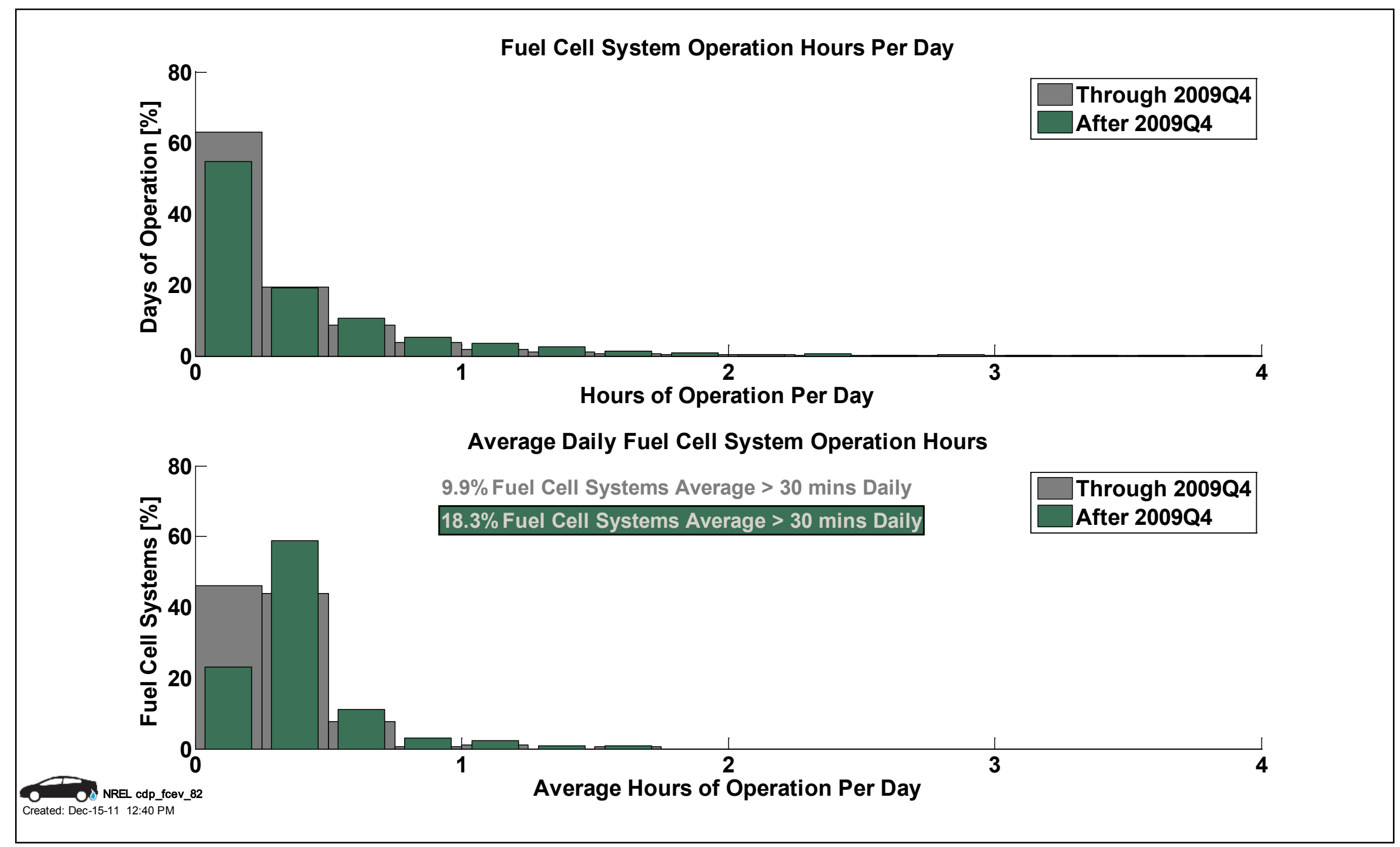




\section{CDP\#83: Hydrogen Dispensed by Day of Week}

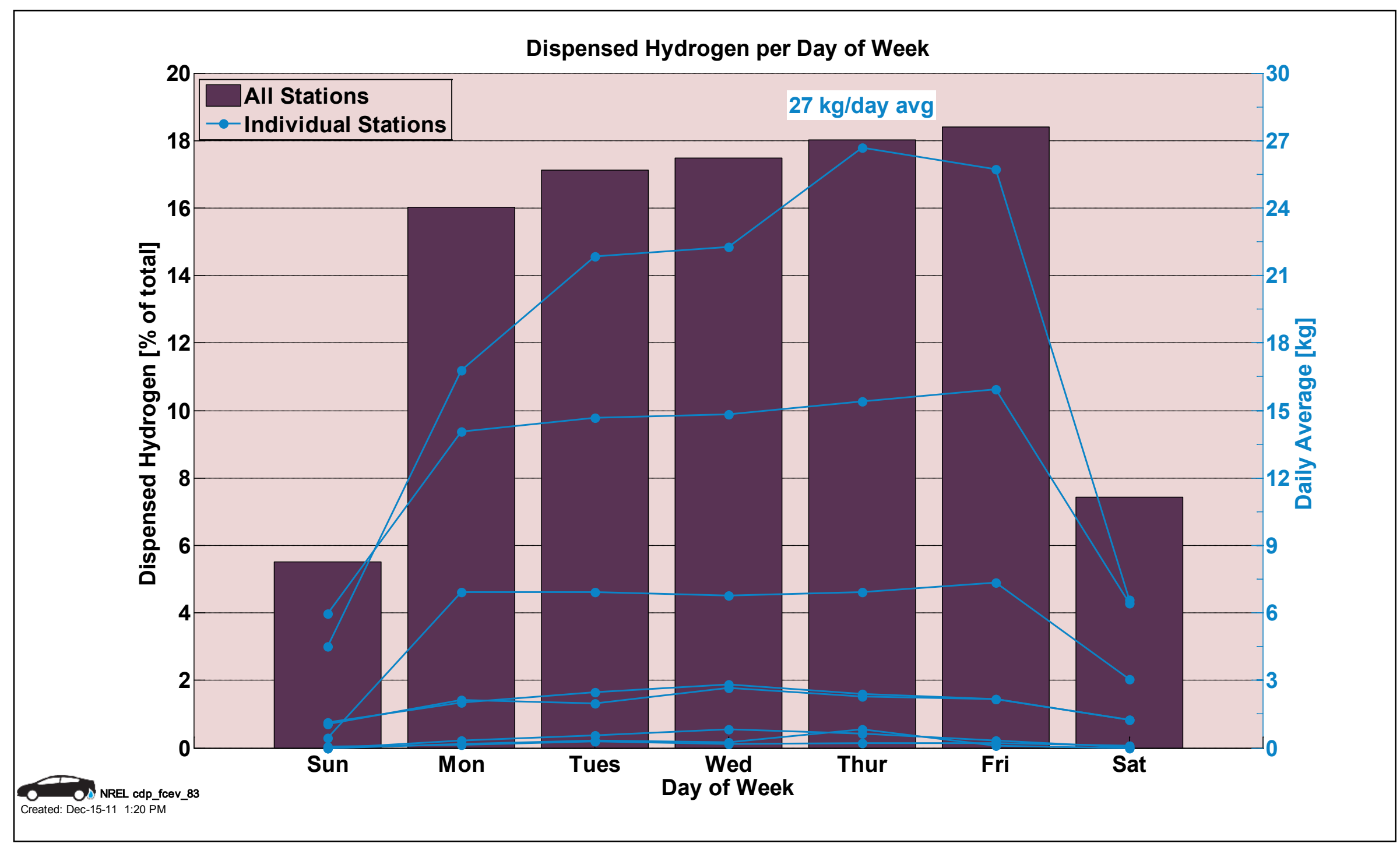




\section{CDP\#84: Effect of Average Trip Speed on Fuel Economy}

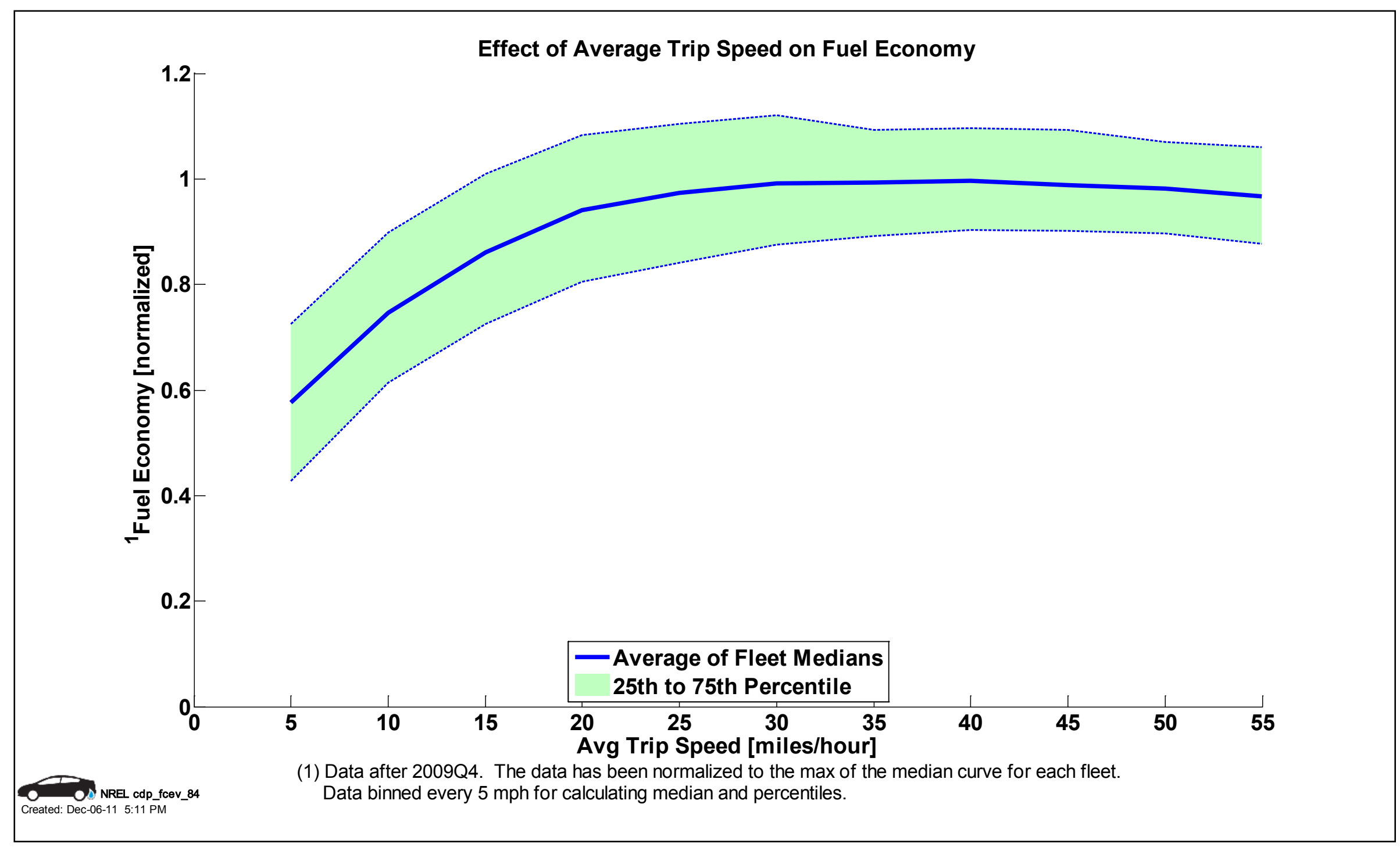




\section{CDP\#85: Effect of Trip Length on Fuel Economy}

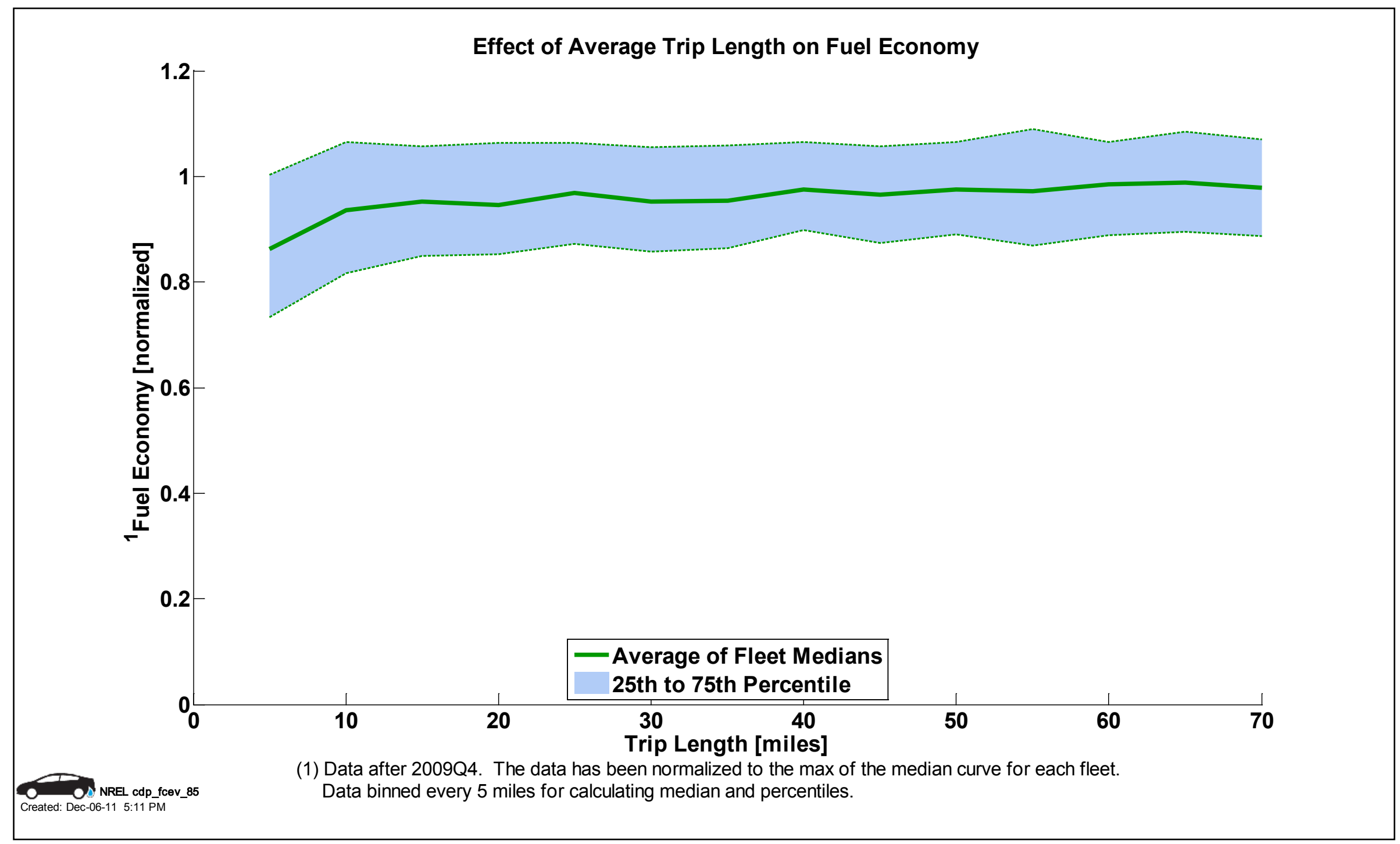




\section{CDP\#86: Fuel Cell Stack Operation Hours}

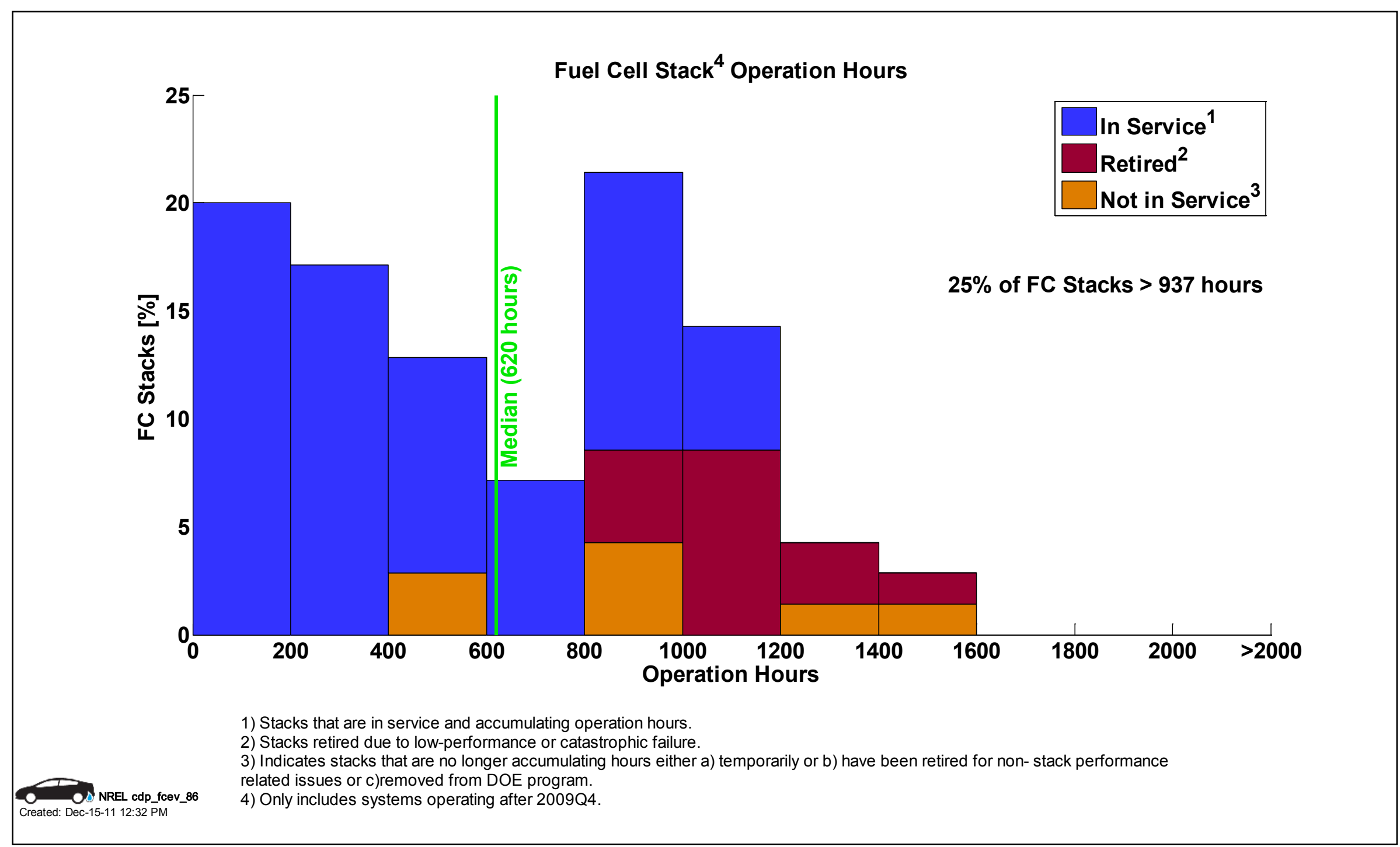




\section{CDP\#87: Fuel Cell Stacks Projected Hours to $10 \%$ Voltage Degradation with Two Fits}
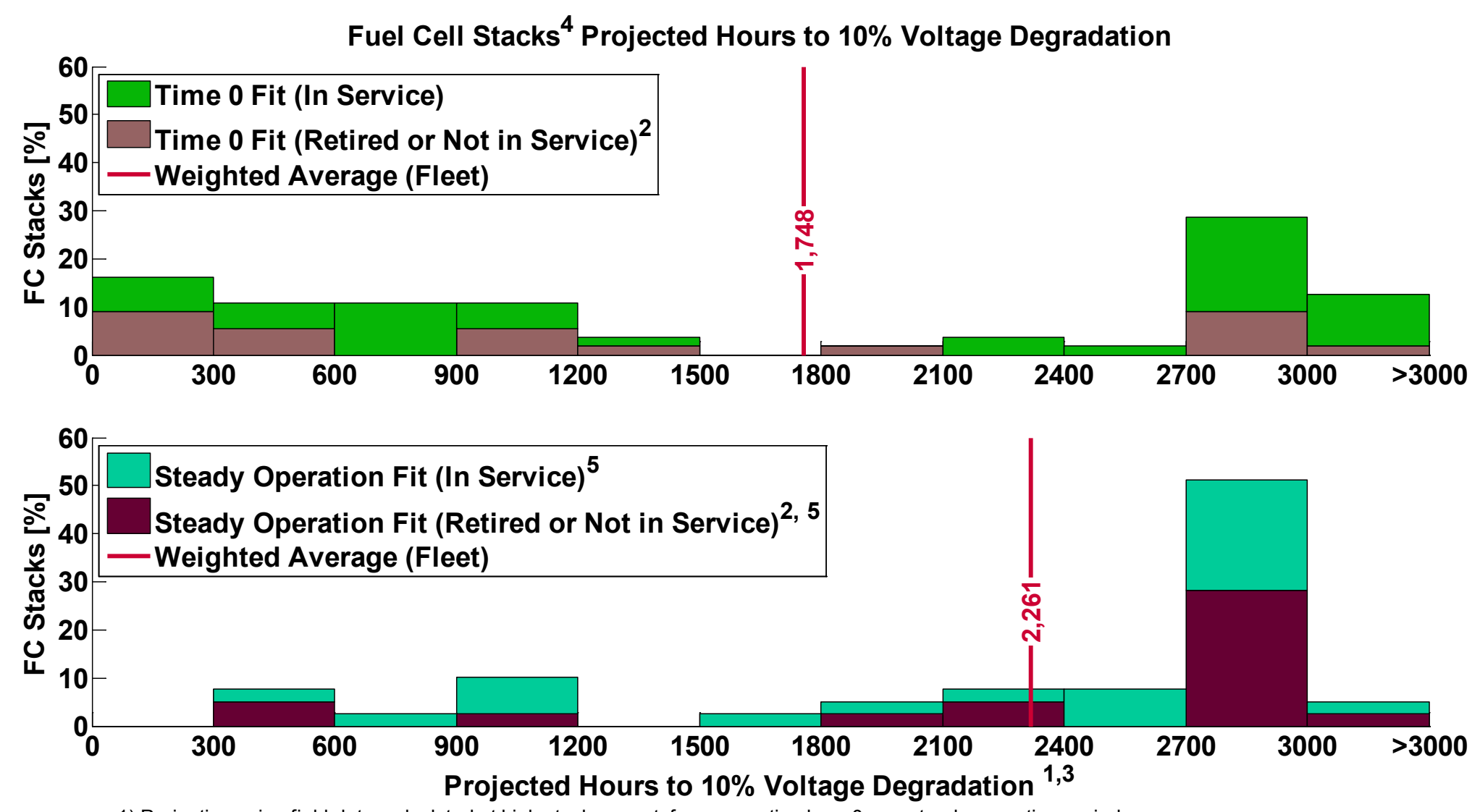

1) Projection using field data, calculated at high stack current, from operation hour 0 or a steady operation period.

Projected hours may differ from an OEM's end-of-life criterion and does not address "catastrophic" failure modes.

2) Indicates stacks that are no longer accumulating hours either a) temporarily or b) have been retired for non- stack performance related issues or c) removed from DOE program.

3) Projected hours limited based on demonstrated hours.

4) Only includes systems operating after 2009Q4.

5) Not all stacks have a steady operation fit which is calculated from data after $200 \mathrm{hr}$ break-in period. The steady operation starting hour is an approximation of the period after initial break-in where degradation levels to a more steady rate. 


\section{CDP\#88: Comparison of Fuel Cell Operation Hours and Projected Hours to $10 \%$ Voltage Degradation}

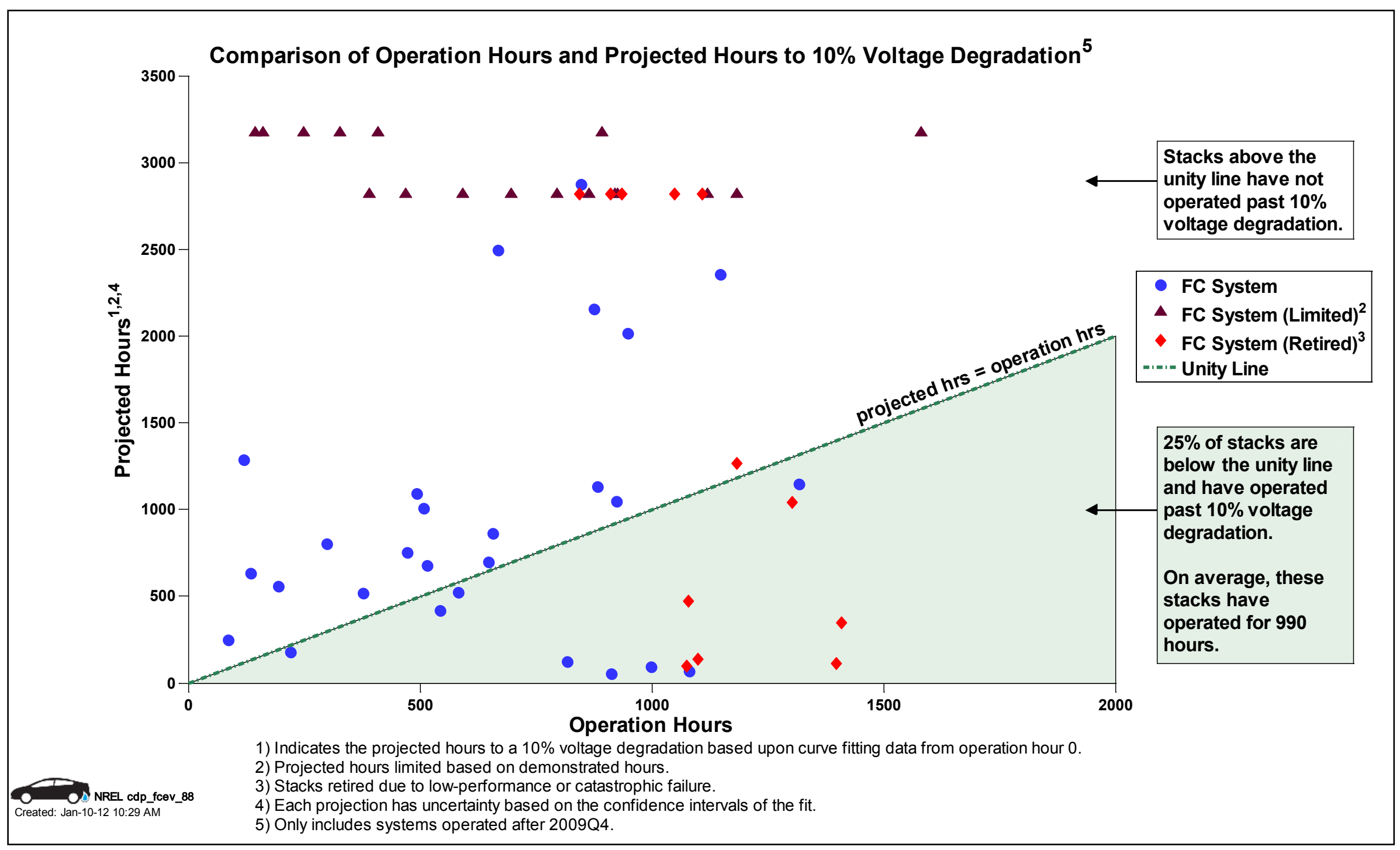




\section{CDP\#89: Fuel Cell Stack Durability as a Function of Voltage Drop}

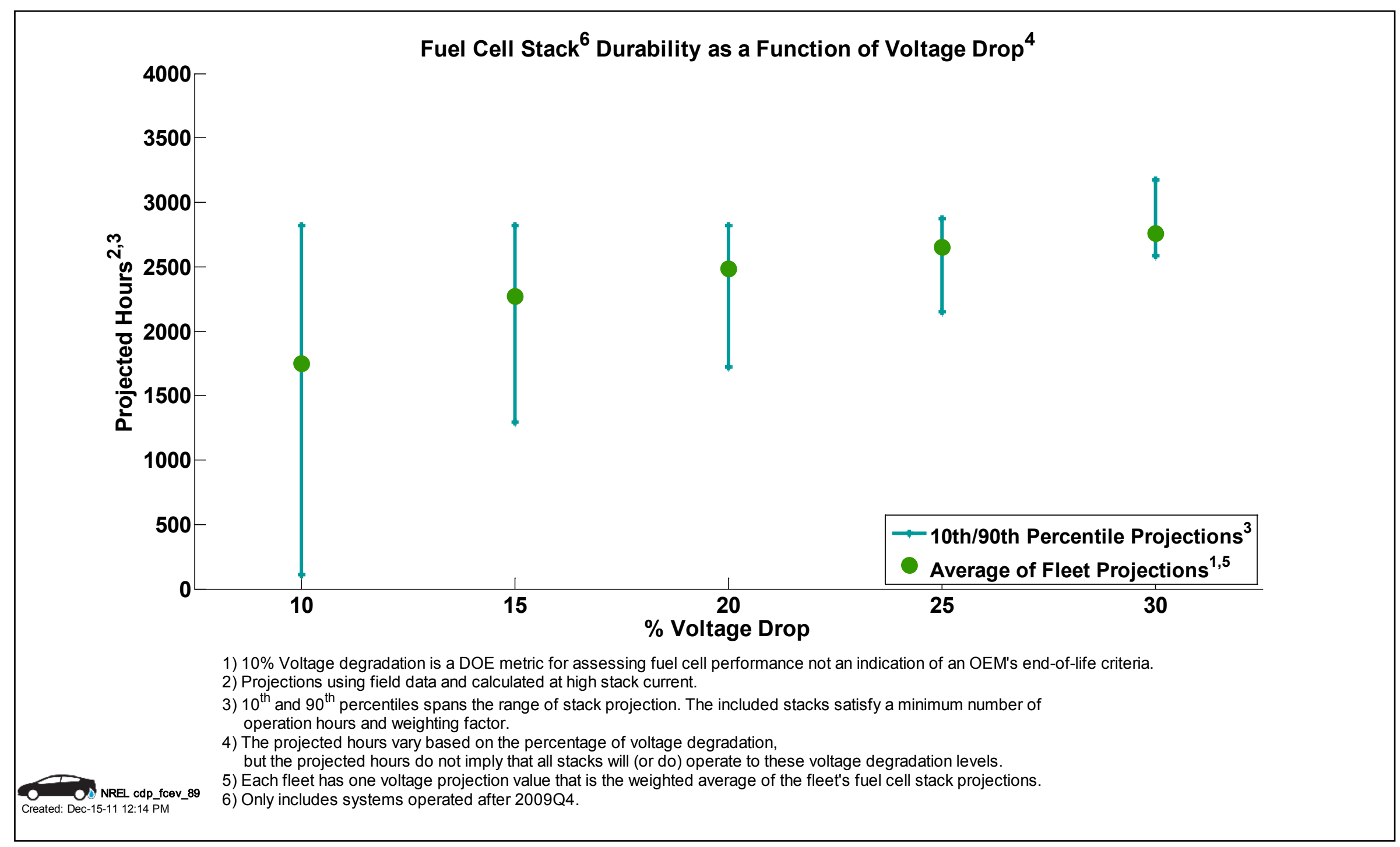




\section{CDP\#90: Max Fuel Cell Stack Power Degradation Over Operation}

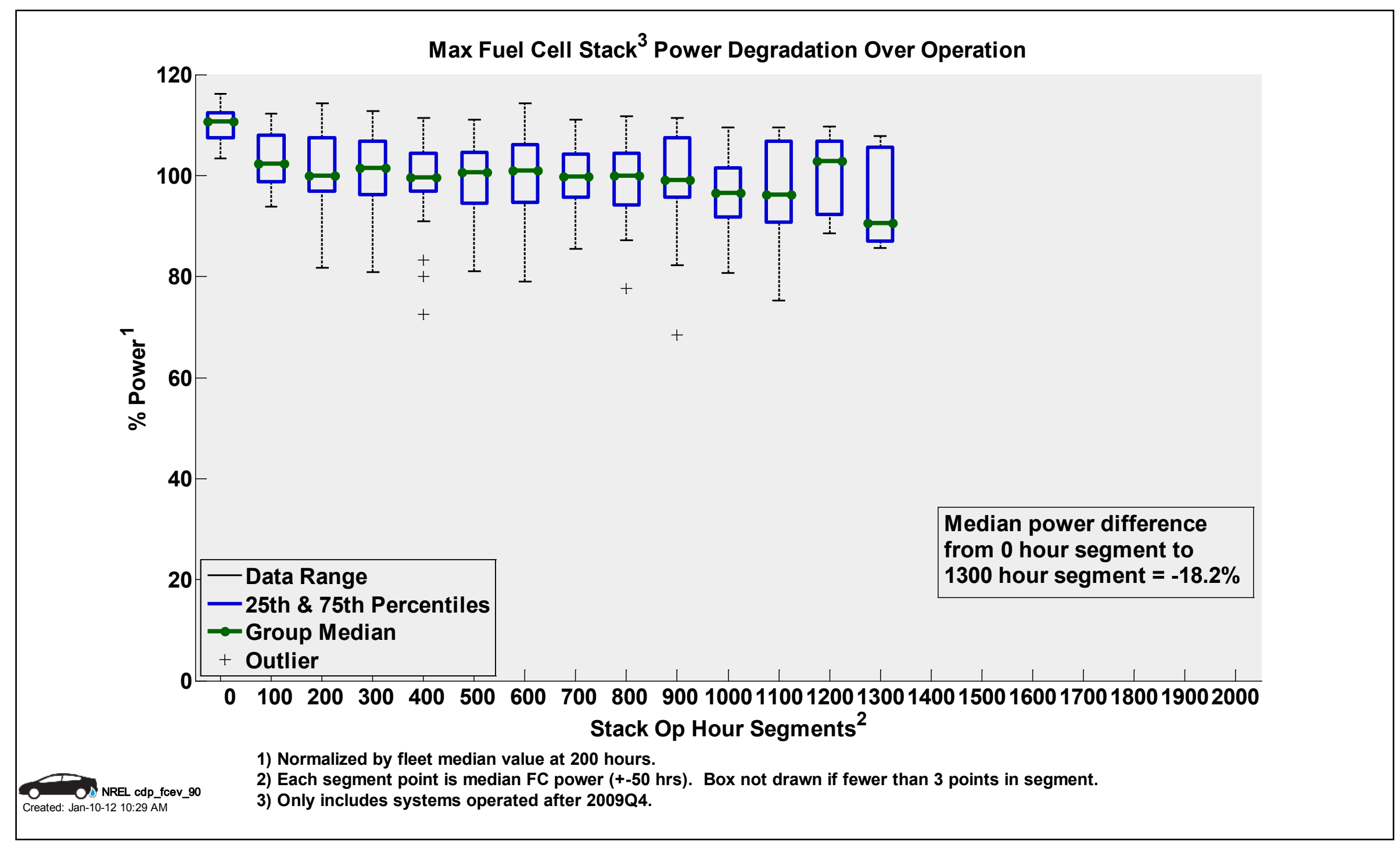




\section{CDP\#91: Station Capacity Utilization}

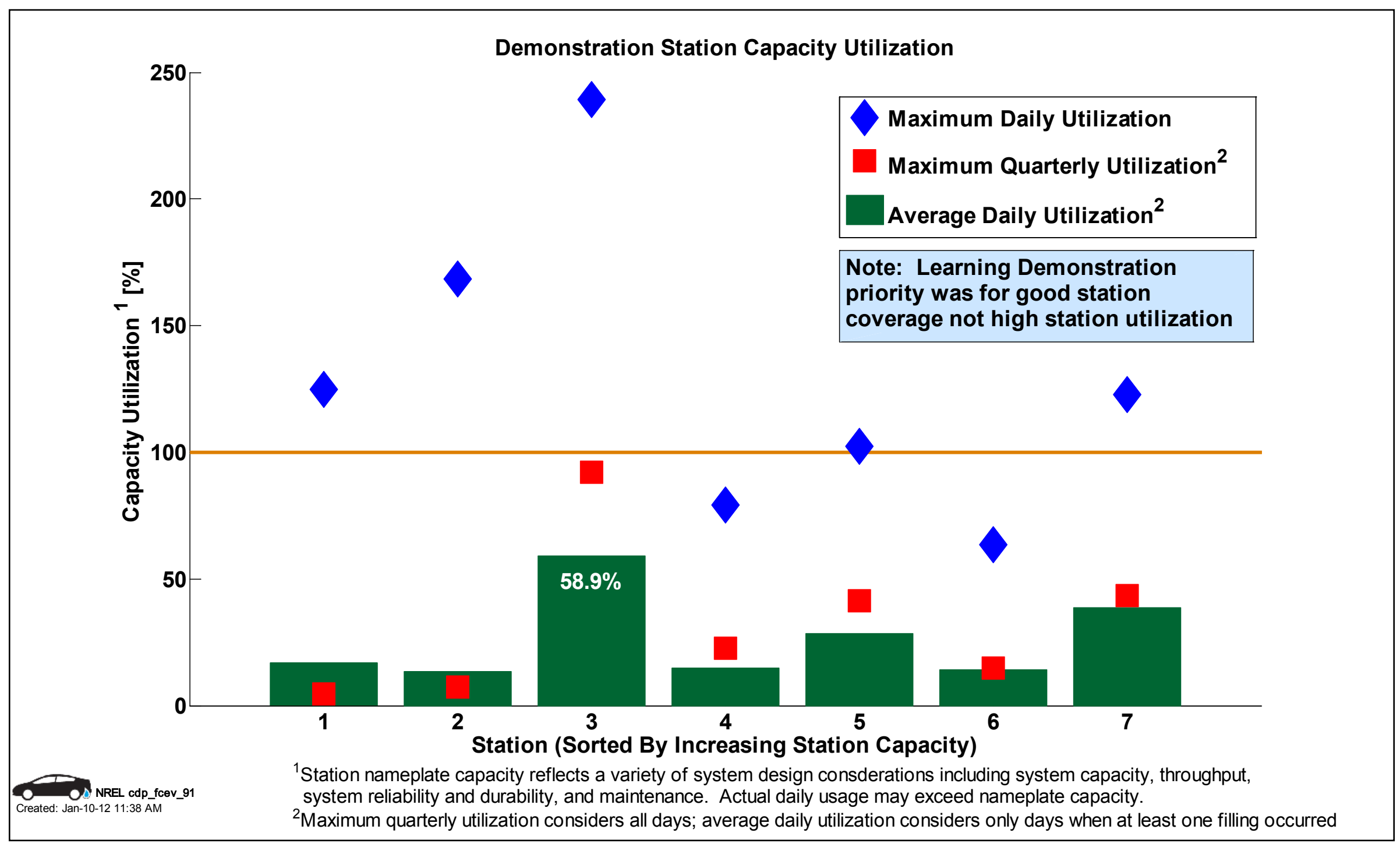




\section{CDP\#92: Station Usage (fills per day)}

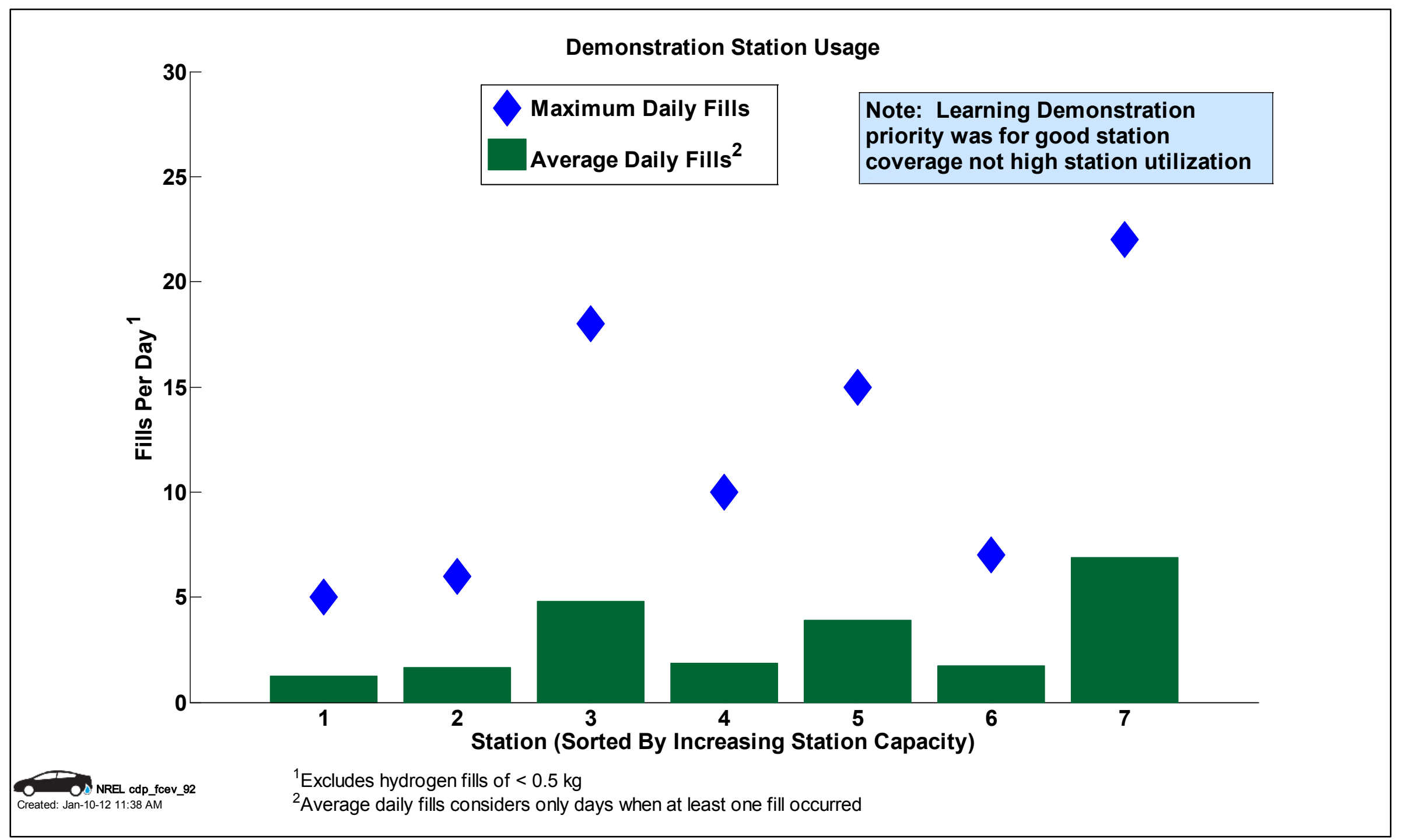




\section{CDP\#93: Hydrogen Equipment Footprint}

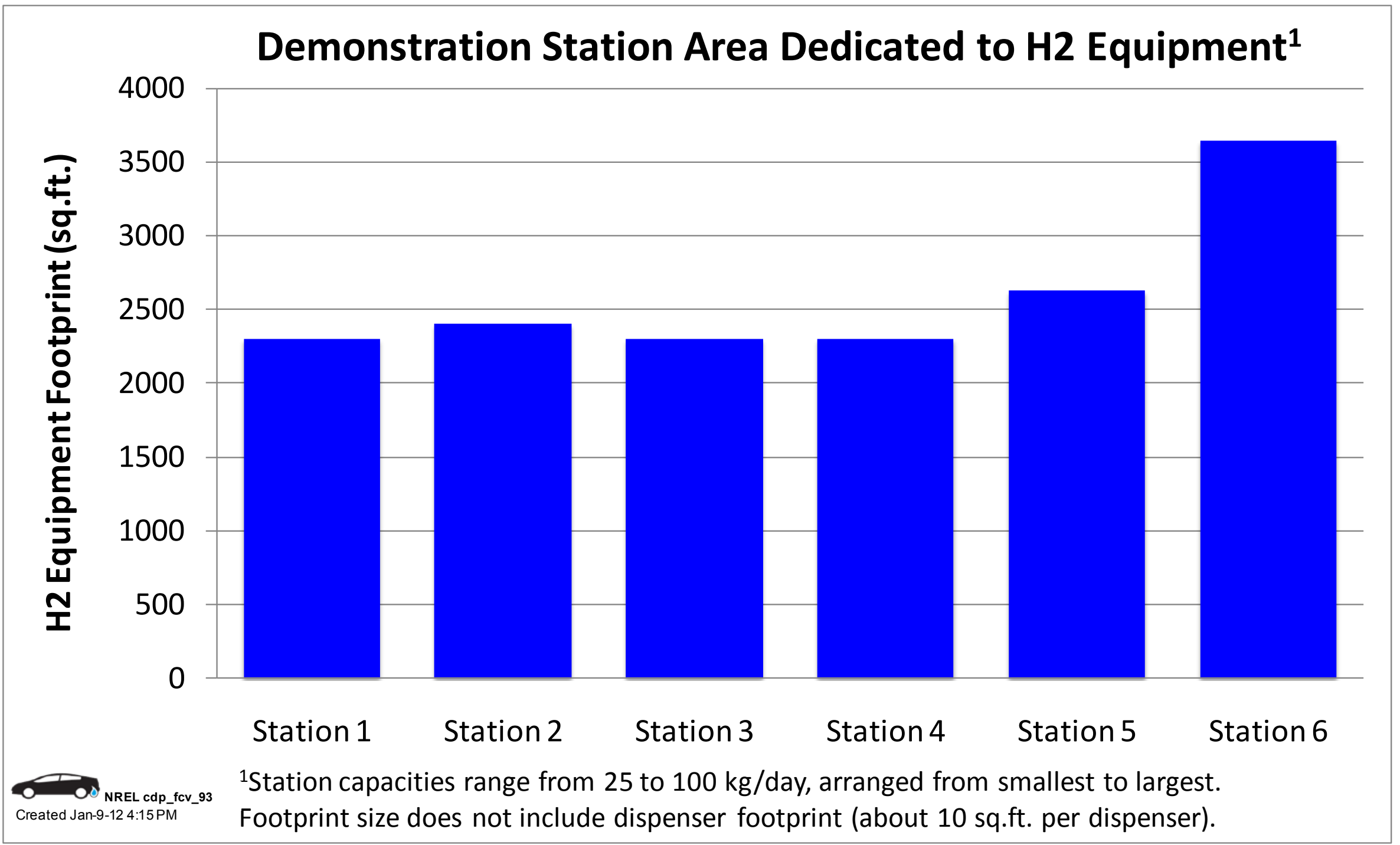




\section{CDP\#94 Infrastructure Maintenance by Category}

Infrastructure Maintenance By Equipment Type ${ }^{2}$
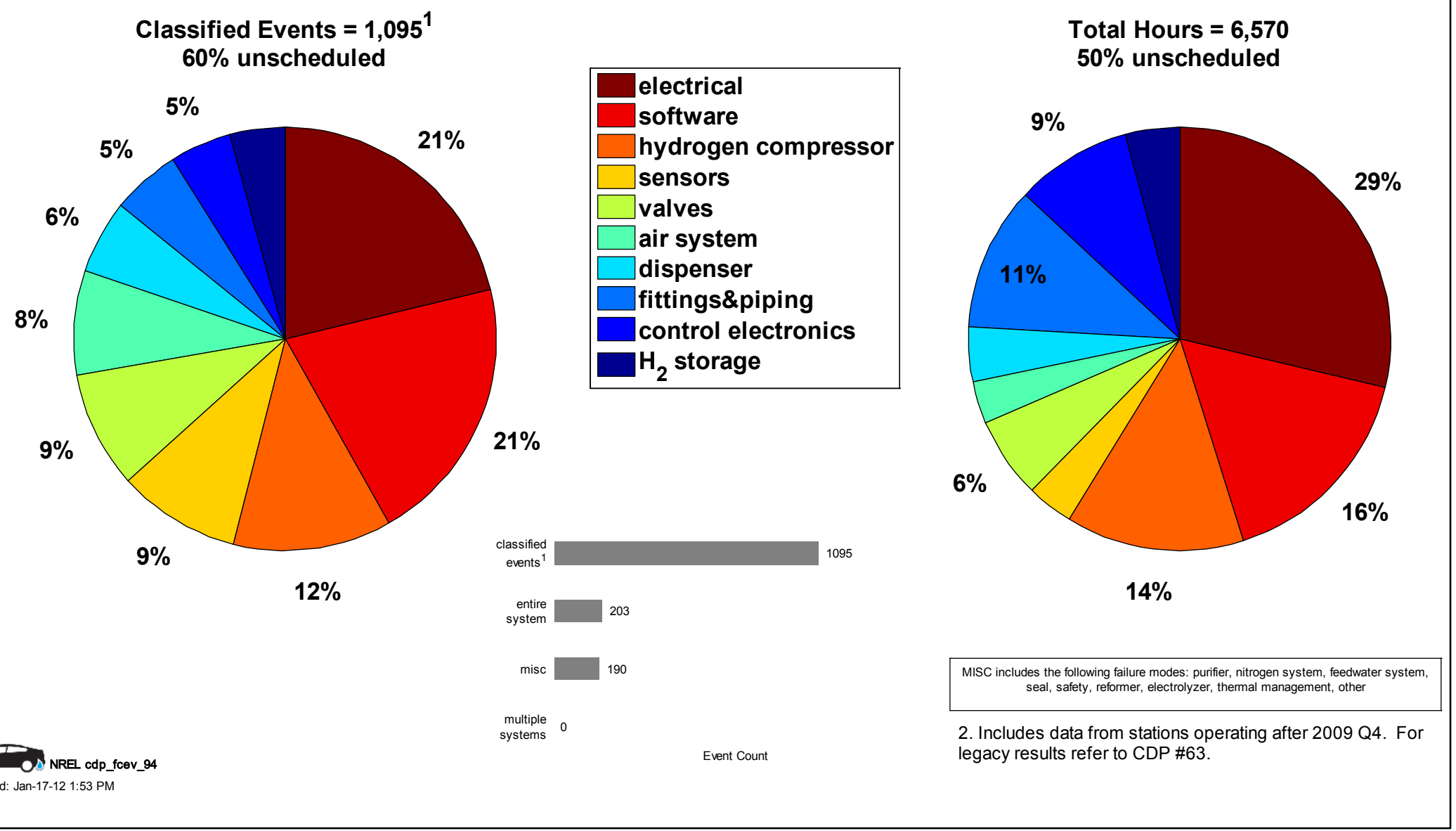


\section{CDP\#95 Infrastructure Maintenance By Quarter}

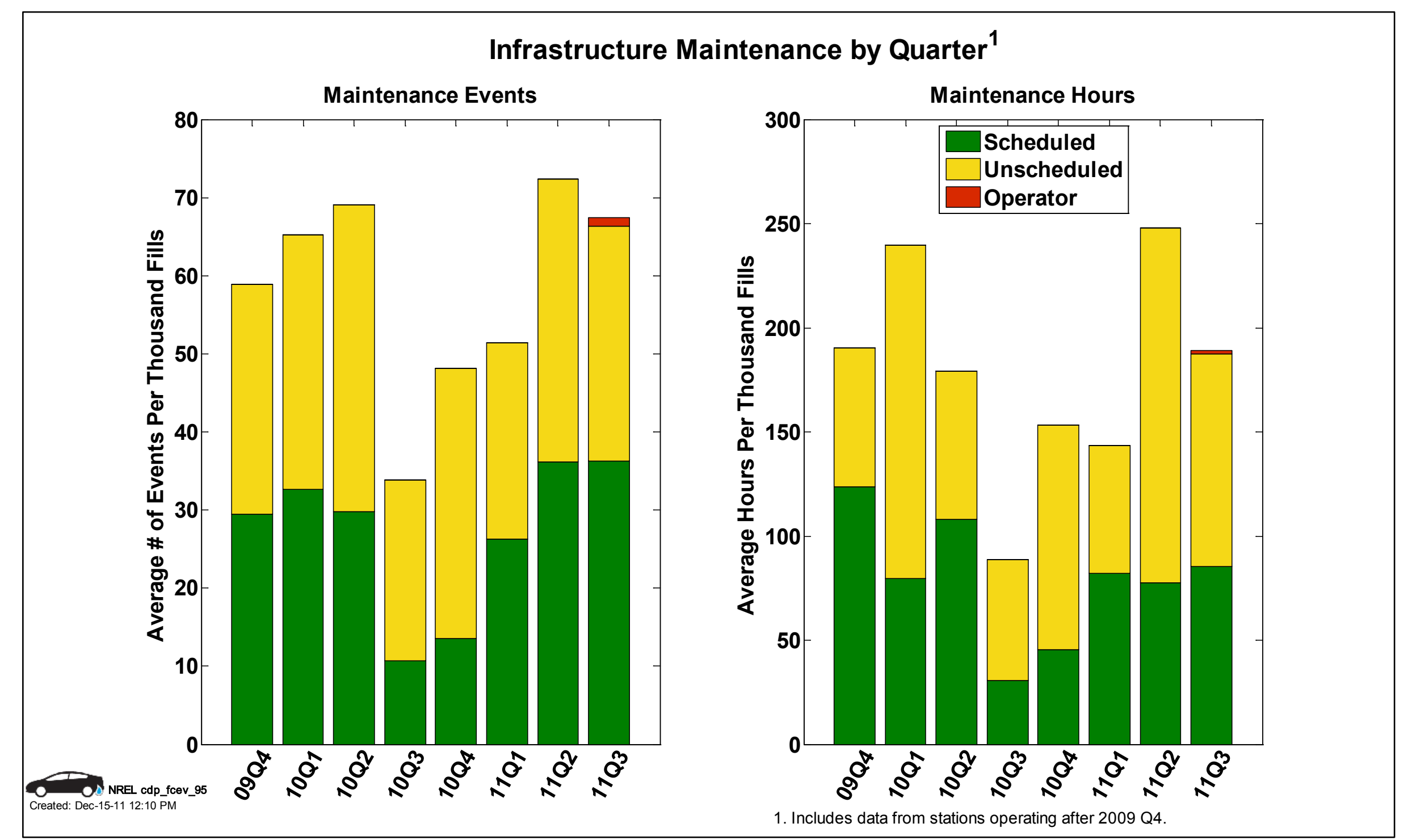




\section{CDP\#96 Infrastructure Maintenance Labor}

\section{Hours}

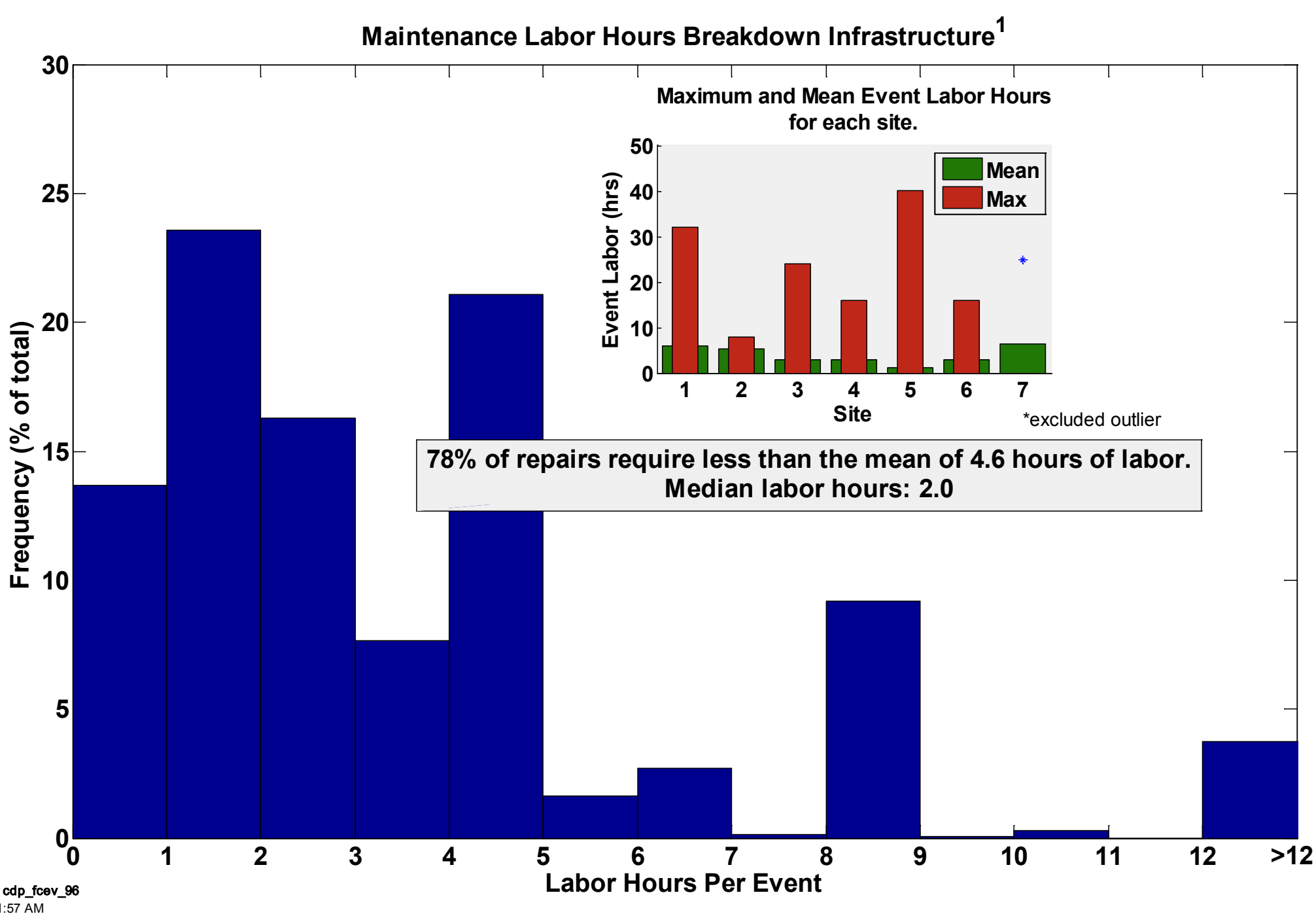

1. Includes data from stations operating after 2009 Q4. 


\section{CDP\#97 Infrastructure Reliability Growth}

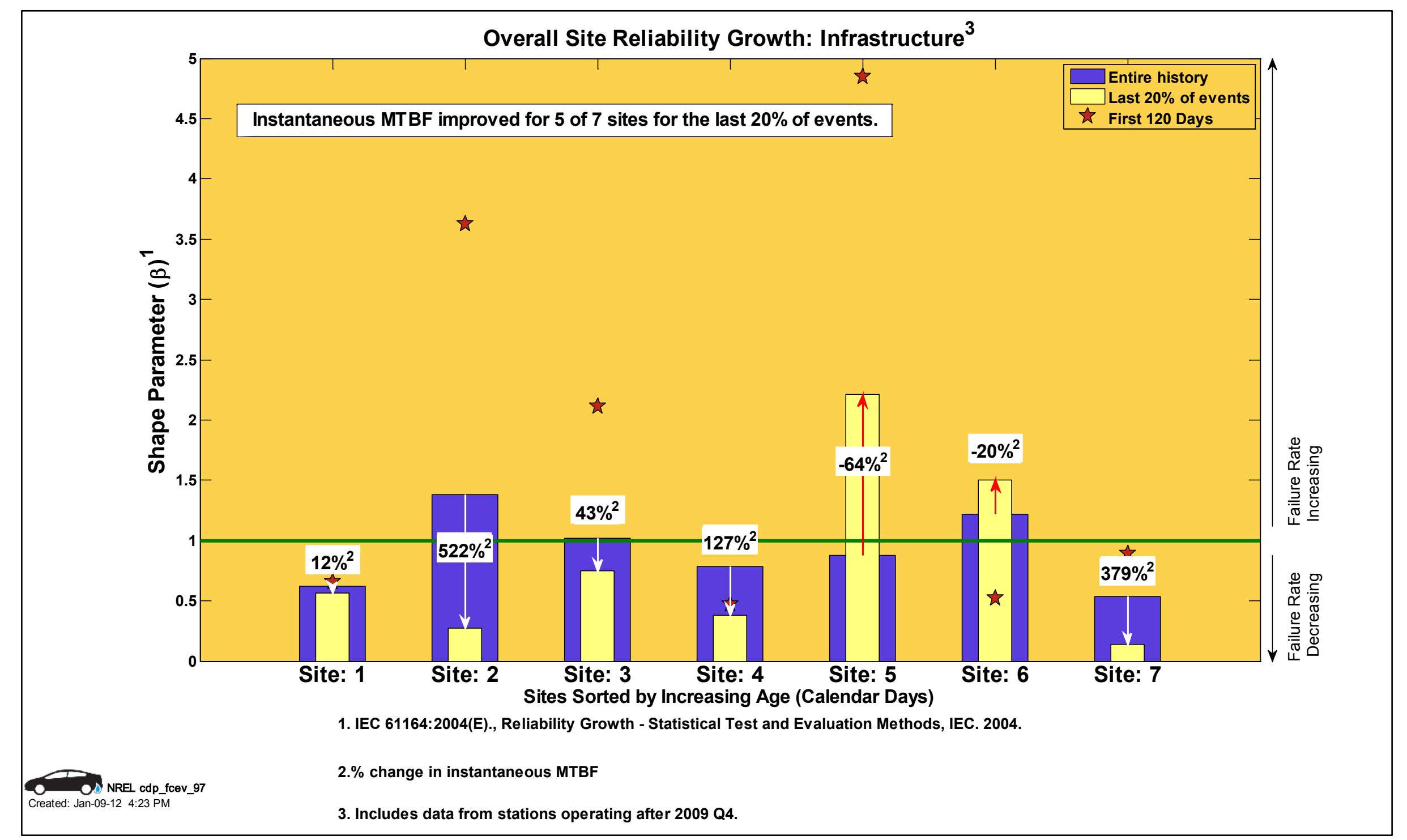




\section{CDP\#98 Infrastructure MTBF (based on Calendar Days of Operation)}

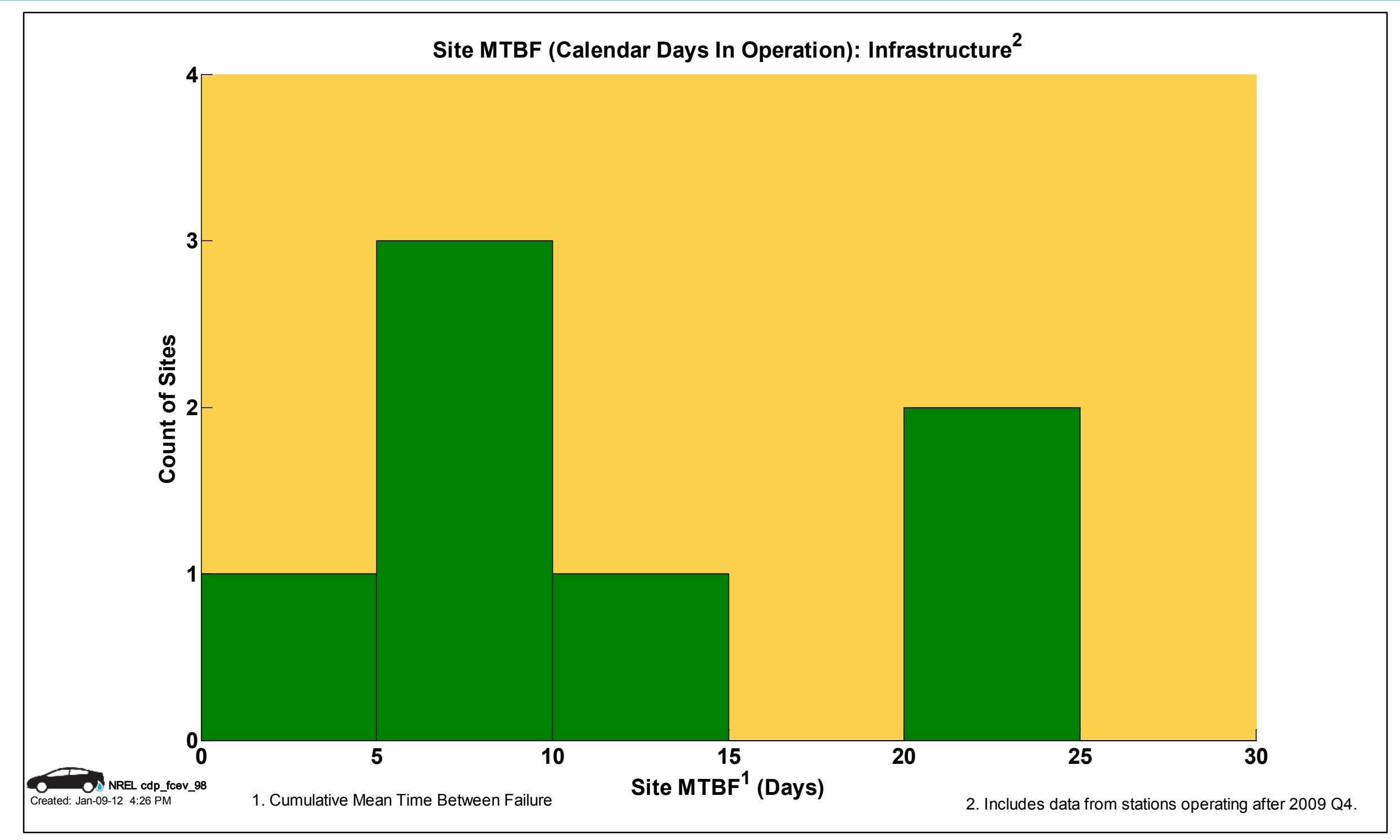




\section{CDP\#99 Infrastructure Mean Time between Scheduled Maintenance}

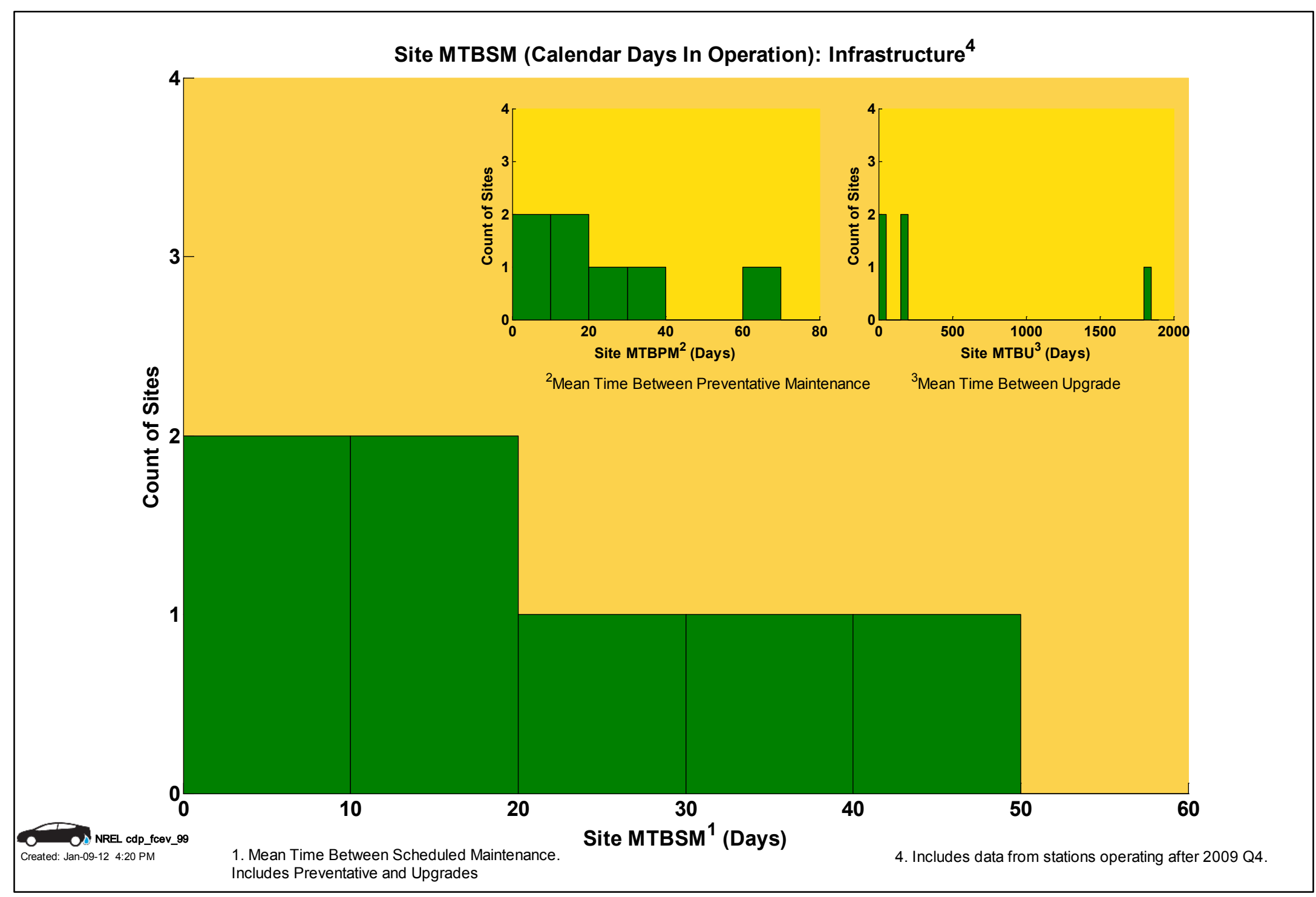

